\title{
A Consideration of Biomarkers to be used for Evaluation of Inflammation in Human Nutritional Studies
}

\author{
P.C. Calder ${ }^{1}$, N. Ahluwalia ${ }^{2}$, R. Albers ${ }^{3,4}$, N. Bosco ${ }^{5}$, R. Bourdet-Sicard ${ }^{6}$, \\ D. Haller ${ }^{7}$, S.T. Holgate ${ }^{1}$, L.S. Jönsson ${ }^{8}$, M.E. Latulippe ${ }^{8}$, A. Marcos ${ }^{9}$, \\ J. Moreines ${ }^{10}$, C. M'Rini ${ }^{11}$, M. Müller ${ }^{12}$, G. Pawelec ${ }^{13}$, R.J.J. van Neerven ${ }^{14}$, \\ B. Watzl ${ }^{15}$ and J. Zhao ${ }^{16}$ \\ 1. University of Southampton, Southampton SO16 6YD, UK \\ 2. Inserm U557, University of Paris 13 , Bobigny, France \\ 3. Unilever R\&D, 3130 AC, Vlaardingen, The Netherlands \\ 4. Nutrileads, $3235 \mathrm{KT}$, Rockanje, The Netherlands \\ 5. Nestlé Research Center, 1000 Lausanne, Switzerland \\ 6. Danone Research, 91767 Palaiseau, France \\ 7. Technical University of Munich, 85354 Freising, Germany \\ 8. ILSI Europe, 1200 Brussels, Belgium \\ 9. ICTAN-CSIC Spanish National Research Council, Madrid 28040, Spain \\ 10. Pfizer, Madison, NJ 07940, USA \\ 11. Institut Mérieux, 69002 Lyon, France \\ 12. Wageningen University, $6703 \mathrm{HD}$, Wageningen, The Netherlands \\ 13. University of Tübingen, D-72072 Tübingen, Germany \\ 14. FrieslandCampina, 3818 LE, Amersfoort, The Netherlands \\ 15. Max Rubner-Institut, 76131 Karlsruhe, Germany \\ 16. Yakult Europe, 1332 EN, Almere, The Netherlands
}




\title{
Table of Contents
}

Biomarkers of inflammation

$\begin{array}{lr}\text { Modifiers of inflammatory markers } & \text { S9-S16 }\end{array}$

Challenge models

S16-S20

Emerging markers of inflammation

S20-S22

Emerging technologies

S22-S24

Summary, conclusions, identification of key gaps, overall recommendations and overall key messages

Key words: Inflammation: Leucocytes: Cytokines: Chemokines: Acute phase

Correspondence: ILSI Europe a.i.s.b.l., Av. E. Mounier 83, Box 6, 1200 Brussels, Belgium, fax: +32 276200 44, email: publications@ilsieurope.be

\begin{abstract}
Abbreviations: ASCA, anti-Saccharomyces cerevisiae antibodies; CPN, chaperone; CRP, C-reactive protein; ER, endoplasmic reticulum; IBD, inflammatory bowel disease; ICAM, intercellular adhesion molecule; ILSI, International Life Sciences Institute; LPS, lipopolysaccharide; MCP, monocyte chemoattractant protein; miRNA, microRNA; OGTT, oral glucose tolerance test; P-ANCA, perinuclear anti-neutrophil cytoplasmic antibodies; RA, rheumatoid arthritis; UPR, unfolded protein response; VCAM, vascular cell adhesion molecule; Xbp-1, X-box binding protein 1.
\end{abstract}

(C) ILSI Europe [2013] 
To monitor inflammation in a meaningful way, the markers used must be valid: they must reflect the inflammatory process under study and they must be predictive of future health status. In 2009, the Nutrition and Immunity Task Force of the International Life Sciences Institute, European Branch, organized an expert group to attempt to identify robust and predictive markers, or patterns or clusters of markers, which can be used to assess inflammation in human nutrition studies in the general population. Inflammation is a normal process and there are a number of cells and mediators involved. These markers are involved in, or are produced as a result of, the inflammatory process irrespective of its trigger and its location and are common to all inflammatory situations. Currently, there is no consensus as to which markers of inflammation best represent low-grade inflammation or differentiate between acute and chronic inflammation or between the various phases of inflammatory responses. There are a number of modifying factors that affect the concentration of an inflammatory marker at a given time, including age, diet and body fatness, among others. Measuring the concentration of inflammatory markers in the bloodstream under basal conditions is probably less informative compared with data related to the concentration change in response to a challenge. A number of inflammatory challenges have been described. However, many of these challenges are poorly standardised. Patterns and clusters may be important as robust biomarkers of inflammation. Therefore, it is likely that a combination of multiple inflammatory markers and integrated readouts based upon kinetic analysis following defined challenges will be the most informative biomarker of inflammation.

The overall aim of the present study is to attempt to identify robust and predictive markers, or patterns or clusters of markers, which can be used to assess inflammation in human nutrition studies in the general population. Inflammation is a normal component of host defence, initiating the mechanisms involved in pathogen killing and protection against other insults. Thus, in a physiological context, inflammation is protective. Typically, the inflammatory response is activated rapidly in response to infection or another trigger and then follows a temporal pattern of cellular activation and chemical mediator release. Once the infection or the other insult is eliminated, or at least controlled, mechanisms come into play to terminate inflammation in order to limit further damage to the host and to initiate tissue repair. This process is termed resolution of inflammation, and it is now recognised to be an active process involving specific mediators that act to down-regulate the processes that were earlier activated. Failure to resolve inflammation may permit the normally acute inflammatory processes to become chronic. Chronic inflammation may also be driven by continuous exposure to the triggering agent. Chronic inflammation is a well-recognised component of many pathologies and is a target for many pharmacologic interventions. In order to examine the role of diet, foods or specific nutrients on inflammation, it is necessary to identify candidate biomarkers. This review describes a systematic approach to identify generic biomarkers of inflammation and to consider the factors that may influence the status of those biomarkers.

\section{Biomarkers of inflammation}

\section{Inflammation: a general overview}

Inflammation is a normal host defence mechanism that protects the host from infection and other insults; it initiates pathogen killing, as well as tissue repair processes, and helps to restore homeostasis at infected or damaged sites ${ }^{(1)}$. A number of different triggers can initiate inflammation. These triggers include the presence of microbial products, tissue damage and metabolic stress (Fig. 1). Exposure to the trigger may involve a breakdown in barrier function or a loss of normal immune tolerance. Irrespective of the nature of the trigger, a common set of cellular pathways is initiated ${ }^{(2)}$. These pathways include activation of signalling via Toll-like receptors and nuclear factor (NF)-кB, formation of a multiprotein complex termed the inflammasome that is responsible for the release of several inflammatory cytokines, and endoplasmic reticulum (ER) stress (Fig. 1) ${ }^{(2)}$. The resulting inflammatory response is typified by redness, swelling, heat, pain and loss of function, and involves interactions among many cell types and the production of, and responses to, a vast number of chemical mediators. The precise timing and vigour of the inflammatory response, including the exact cells and mediators involved, is determined by the nature, extent and location of the trigger. These factors act to shape and maintain the inflammatory response. Once the infection or the other trigger is eliminated, or at least controlled, mechanisms come into play to terminate inflammation in order to limit further damage to the host and to initiate tissue repair. This self-regulating process is termed resolution of inflammation and involves the activation of negative feedback mechanisms such as the secretion of anti-inflammatory cytokines, the inhibition of pro-inflammatory signalling cascades, the shedding of receptors for inflammatory mediators and the activation of regulatory cells. Properly controlled inflammation is essential to remain healthy and maintain homeostasis, but inflammation that involves a loss of tolerance or regulatory processes may become pathological ${ }^{(1)}$.

Inflammation may be classified as acute or chronic (Table 1). Acute inflammation is the initial response of the body to an infectious agent or another inflammatory trigger (e.g. tissue damage by wounding or irradiation) and is achieved by the increased movement of plasma and leucocytes (especially granulocytes) from the blood into the site of infection or injury. A cascade of biochemical events matures and propagates the inflammatory response, involving the local vascular system, the immune system and various cells within the injured tissue. Acute inflammation is typically self-limiting with resolution being activated once the cause of the initial 


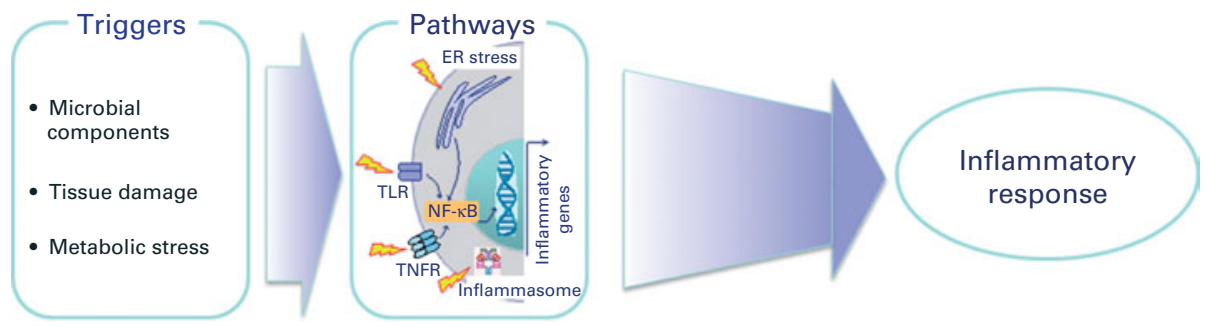

Fig. 1. Schematic overview of the common inflammatory response initiated by different triggers. Triggers are those factors that can directly initiate an inflammatory response. ER, endoplasmic reticulum; TLR, Toll-like receptor; TNFR, TNF receptor.

response is contained or eliminated. Resolution is itself an active process involving specific cell types and specific anti-inflammatory cytokines $^{(3)}$ and pro-resolving lipid mediators $^{(4,5)}$. Prolonged, or chronic, inflammation involves a progressive shift in the type of cells present at the site of inflammation and simultaneous destruction and healing of the tissue due to the ongoing inflammatory process. Inflammation may become pathological due to the loss of tolerance and/or of regulatory processes such as resolution. Where this becomes excessive, irreparable damage to host tissues and disease can occur ${ }^{(1)}$. Such diseases are characterised by markedly elevated concentrations of inflammatory markers and of activated inflammatory cells at the site of tissue damage and in the systemic circulation; this state of inflammation may be regarded as 'high grade'. These diseases include rheumatoid arthritis (RA), inflammatory bowel diseases (IBD), atopic dermatitis, psoriasis and asthma. Chronic inflammation can also be of a 'low grade' and under such circumstances, overt clinical manifestations can be minimal or absent; the elevation in the concentrations of inflammatory markers and of inflammatory cells in the systemic circulation is not as great as that seen in the frank chronic inflammatory conditions described above. Low-grade asymptomatic inflammation can occur in adipose tissue as a feature of obesity ${ }^{(6)}$. Under these conditions, the adipocyte itself becomes the source of inflammationassociated adipokines, although there is also infiltration of adipose tissue by macrophages and $\mathrm{T}$ cells, which make important contributions to the inflammatory output from adi- pose tissue ${ }^{(7)}$. The cytokines and adipokines released probably contribute to the insulin resistance seen in obesity ${ }^{(8)}$. Older people also commonly exhibit low-grade chronic inflammation that may contribute to frailty, depending on the plasma levels of factors such as tumor necrosis factor (TNF) and interleukin (IL)-6.

Common to both acute and chronic inflammation is that they have an afferent phase, in which the presence of a trigger is sensed by some types of cells, and an efferent phase, in which an inflammatory response is generated to eliminate the perceived hostile intruder (i.e. the source of the trigger). Irrespective of the type of inflammation, the response involves four major events. The first event is increased blood supply to the site of inflammation. The second event is increased capillary permeability caused by retraction of endothelial cells. This permits larger molecules, not normally capable of traversing the endothelium, to do so and thus delivers some soluble mediators to the site of inflammation. The third event is leucocyte migration from the capillaries into the surrounding tissue (Fig. 2). This is promoted by the release of chemoattractants from the site of inflammation and by the up-regulation of adhesion molecules on the endothelium. Once in the tissue, the leucocytes move to the site of inflammation. The fourth event is the release of mediators from leucocytes at the site of inflammation. These may include lipid mediators (e.g. prostaglandins (PG), leukotrienes; see Table 2), peptide mediators (e.g. cytokines, chemokines; see Table 3), reactive oxygen species (e.g. superoxide),

Table 1. Features of acute, chronic and low-grade chronic inflammation

\begin{tabular}{|c|c|c|c|}
\hline & Acute inflammation & Chronic inflammation & Low-grade chronic inflammation \\
\hline Trigger & Pathogens, injured tissues & $\begin{array}{l}\text { Failure to resolve acute inflammation due } \\
\text { to non-degradable pathogens, persistent } \\
\text { foreign bodies or autoimmune reactions }\end{array}$ & $\begin{array}{l}\text { Metabolic disturbance; some chronic } \\
\text { infections }\end{array}$ \\
\hline $\begin{array}{l}\text { Major cells } \\
\text { involved }\end{array}$ & $\begin{array}{l}\text { Neutrophils and other granulocytes, } \\
\text { mononuclear cells (monocytes, } \\
\text { macrophages); T cells later }\end{array}$ & $\begin{array}{l}\text { Mononuclear cells (monocytes, macro- } \\
\text { phages, T cells, B cells), neutrophils, } \\
\text { fibroblasts }\end{array}$ & $\begin{array}{l}\text { Mononuclear cells (monocytes, macrophages, } \\
\text { T cells, B cells), neutrophils, adipocytes } \\
\text { (if adipose tissue involved) }\end{array}$ \\
\hline $\begin{array}{l}\text { Primary } \\
\text { mediators }\end{array}$ & $\begin{array}{l}\text { Vasoactive amines, eicosanoids; } \\
\text { chemokines and cytokines later }\end{array}$ & $\begin{array}{l}\text { Cytokines, chemokines, eicosanoids, } \\
\text { growth factors, reactive oxygen species, } \\
\text { hydrolytic enzymes }\end{array}$ & $\begin{array}{l}\text { Cytokines, chemokines, adipokines } \\
\text { (if adipose tissue involved), eicosanoids, } \\
\text { reactive oxygen species, hydrolytic enzymes }\end{array}$ \\
\hline Onset & Immediate & Delayed & Delayed \\
\hline Duration & A few days & Unlimited & Unlimited \\
\hline Outcomes & $\begin{array}{l}\text { Resolution, abscess formation, } \\
\text { chronic inflammation }\end{array}$ & Tissue destruction, fibrosis, necrosis & $\begin{array}{l}\text { No overt pathology, tissue (vascular) damage, } \\
\text { increased insulin resistance, intracellular } \\
\text { lipid accumulation }\end{array}$ \\
\hline
\end{tabular}


amino acid derivatives (e.g. histamine) and enzymes (e.g. matrix proteases), depending upon the cell type involved, the nature of the inflammatory trigger, the anatomical site involved and the stage during the inflammatory response. Several of the mediators involved act to amplify the inflammatory process by acting, for example, as chemoattractants. Some of the inflammatory mediators escape the inflammatory site into the circulation and from there, they can exert systemic effects (Fig. 2). For example, the cytokine IL-6 released into the bloodstream from an inflammatory locus induces hepatic synthesis of the acute-phase protein C-reactive protein (CRP), while the cytokine TNF elicits metabolic effects within skeletal muscle, adipose tissue and bone. Thus, inflammation at one site, such as within the intestinal mucosa, can cause inflammation-driven changes at distal sites, such as in bone.

\section{The need to identify biomarkers of inflammation}

Inflammation has long been recognised to play a key role in the pathology of a number of human diseases, including RA, psoriasis, Crohn's disease, allergic asthma and atopic dermatitis, being centrally involved in the tissue damage that is seen. These diseases with a well-recognised inflammatory component are usually treated with general or specific antiinflammatory pharmaceuticals with the aim of inducing a clinical benefit. More recently, it has become clear that metabolic diseases such as atherosclerosis, type 2 diabetes and obesity have an inflammatory component ${ }^{(6,9-11)}$, albeit low-grade; however, the extent to which this is causal in the pathology is not yet clear. These diseases are not usually treated with anti-inflammatory pharmaceuticals. It is considered that many dietary factors can influence various aspects of inflammation $^{(1,6)}$; thus, nutrition may play a role in predisposing to

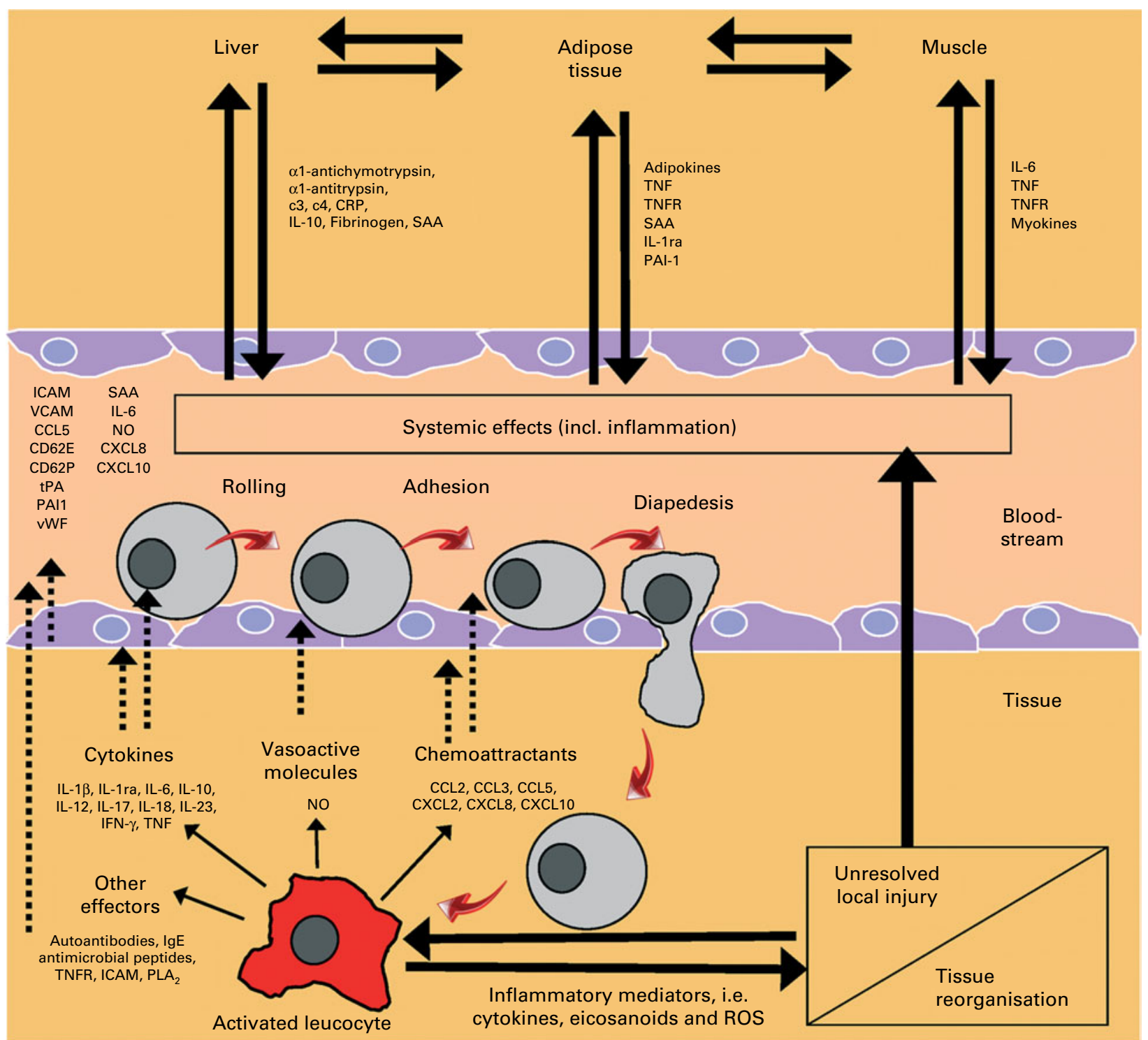

Fig. 2. An overview of inflammation. C, complement; CRP, C-reactive protein; SAA, serum amyloid A; TNFR, TNF receptor; ra, receptor antagonist; PAI, plasminogen activator inhibitor; ICAM, intercellular adhesion molecule; VCAM, vascular cell adhesion molecule; CCL, chemokine (C-C motif) ligand; CD62E, E-selectin endothelial leukocyte adhesion molecule 1; CD62P, P-selectin endothelial leukocyte adhesion molecule 1; CXCL, chemokine (C-X-C motif) ligand; tPA, tissue plasminogen activator; vWF, von Willebrand factor; IFN, interferon; PLA, phospholipase A; ROS, reactive oxygen species. 
Table 2. Lipid mediators associated with inflammation*

\begin{tabular}{|c|c|c|c|}
\hline Class & Mediator & Substrate & Receptor(s) \\
\hline \multirow[t]{8}{*}{ Prostanoids } & $\mathrm{PGD}_{2}$ & Arachidonic acid via COX & DP1, DP2 \\
\hline & $\mathrm{PGE}_{2}$ & Arachidonic acid via COX & EP1, EP2, EP3, EP4 \\
\hline & $\mathrm{PGF}_{2 \alpha}$ & Arachidonic acid via COX & $\mathrm{FP}$ \\
\hline & $\mathrm{PGI}_{2}$ & Arachidonic acid via COX & IP \\
\hline & $\mathrm{TXA}_{2}$ & Arachidonic acid via COX & TP \\
\hline & $\mathrm{PGE}_{1}$ & Dihomo- $\gamma$-linolenic acid via COX & EP1, EP2, EP3, EP4 \\
\hline & $\mathrm{PGD}_{3}$ & EPA via COX & DP1, DP2 \\
\hline & $\mathrm{PGE}_{3}$ & EPA via COX & EP1, EP2, EP3, EP4 \\
\hline \multirow[t]{8}{*}{ Leukotrienes } & 5-HETE & Arachidonic acid via 5-LOX & BLT2 \\
\hline & 5-HPETE & Arachidonic acid via 5 -LOX & OXE \\
\hline & $\mathrm{LTB}_{4}$ & Arachidonic acid via 5-LOX & BLT1, BLT2 \\
\hline & $\mathrm{LTC}_{4}, \mathrm{D}_{4}, \mathrm{E}_{4}$ (termed cys-LT) & Arachidonic acid via 5-LOX & CysLT1, CysLT2 \\
\hline & 15-HETE & Arachidonic acid via 15 -LOX & BLT2 \\
\hline & 15-HPETE & Arachidonic acid via $15-$ LOX & BLT2 \\
\hline & 12-HETE & Arachidonic acid via 12 -LOX & BLT2 \\
\hline & $\mathrm{LTB}_{5}$ & EPA via 5-LOX & BLT1, BLT2 \\
\hline Lipoxins & $\mathrm{LXA}_{4}$ & $\begin{array}{l}\text { Arachidonic acid via 15-LOX and 5-LOX or 5-LOX } \\
\text { and 12-LOX (transcellular) }\end{array}$ & FPR2/ALX \\
\hline \multirow[t]{2}{*}{ Endocannabinoids } & 2-Arachidonoylglycerol & $\begin{array}{l}\text { 1,2-Diacylglycerol with arachidonic acid at the sn-2 } \\
\text { position }\end{array}$ & CB1, CB2 \\
\hline & Anandamide & $\begin{array}{l}N \text {-arachidonoylphosphatidylethanolamide via phos- } \\
\text { pholipase } \mathrm{D} \text {; in turn, } N \text {-arachidonoylphosphatidy- } \\
\text { lethanolamide is formed from phosphatidylcholine } \\
\text { with arachidonic acid at the sn-1 position and } \\
\text { phosphatidylethanolamine }\end{array}$ & CB1, CB2 \\
\hline \multirow{4}{*}{$\begin{array}{l}\text { Resolvins, protectins } \\
\text { and maresins }\end{array}$} & RvE1 & EPA via acetylated COX-2 and 5-LOX (transcellular) & RvE1 (ChemR23), BLT1 \\
\hline & RvD1 & $\begin{array}{l}\text { DHA via acetylated COX-2 and 5-LOX or via 15-LOX } \\
\text { and 5-LOX (transcellular) }\end{array}$ & RvD1 (GPR32), ALX/FPR2 \\
\hline & PD1 (NPD1) & DHA via 15-LOX and LOX (transcellular) & Not yet known \\
\hline & MaR1 & DHA via 15-LOX and 12-LOX (transcellular) & Not yet known \\
\hline \multirow[t]{3}{*}{ Lysolipids } & PAF & $\begin{array}{l}\text { Phosphatidylcholine with diethyl ether link at the } s n-1 \\
\text { position }\end{array}$ & PAF-R \\
\hline & Lyso-PA & $\begin{array}{l}\text { Phosphatidic acid, which in turn is synthesised } \\
\text { from phosphatidylcholine }\end{array}$ & $\begin{array}{l}\text { LPA1, LPA2, LPA3, LPA4, } \\
\text { LPA5, LPA6 }\end{array}$ \\
\hline & Sphingosine-1-phosphate & $\begin{array}{l}\text { Sphingosine, which in turn is synthesised from } \\
\text { ceramide }\end{array}$ & S1P1, S1P2, S1P3, S1P4, S1P5 \\
\hline
\end{tabular}

COX, cyclo-oxygenase; TX, thromboxane; HETE, hydroxyeicosatetraenoic acid; LOX, lipoxygenase; HPETE, hydroperoxyeicosatetraenoic acid; cys, cysteinyl; LT, leukotriene; LX, lipoxin; Rv, resolvin; P, protectin; NP, neuroprotectin; MaR, maresin; PAF, platelet-activating factor; Lyso-PA, lysophosphatidic acid; DP, EP, FP, IP, TP, prostanoid receptors; BLT, leukotriene B4 receptors; OXE, oxoeicosanoid receptor; D4, E4, Leukotriene receptors; FPR2, formyl peptide receptor 2; ALX, oncogenic receptor tyrosine kinase; CB, cannabinoid receptor; ChemR23, chemokine receptor-like 1 (also known as Chemerin receptor 23); RvD, resolving D; GPR32, G protein-coupled receptor 32; LP, lysophospholipid; S1P, sphingosine-1-phosphate.

${ }^{*}$ Note that the listing is not exhaustive.

conditions that have an inflammatory component and altered nutrition may be useful in the prevention or treatment of such conditions $^{(1,6)}$.

In order to elucidate the role of diet or its component foods, nutrients and non-nutrients in inflammation, either as a predisposing, preventative or therapeutic factor, there is a need to be able to monitor the inflammatory process in the subjects being studied. This requires the identification of biomarkers of inflammation. A biomarker is defined as 'a characteristic that is objectively measured and evaluated as an indicator of normal biological processes, pathogenic processes, or pharmacologic responses to an intervention, ${ }^{,(12)}$. However, clear recommendations on which biomarkers to use and how to interpret patterns of biomarkers and changes in biomarkers in the context of inflammation are lacking. The Institute of Medicine recently presented a general concept for identification of biomarkers and surrogate endpoints in chronic diseases $^{(13)}$. The Institute of Medicine recommended basing the evaluation process for biomarkers on three steps:
(1) analytical validation of the biomarker (reference range, accuracy, limits of detection, reproducibility, etc.); (2) qualification of the available evidence on an association between the biomarker and disease states including data showing the effects of an intervention on both the biomarker and clinical outcomes; (3) use of a utilisation step that primarily includes the determination of whether analytical validation and qualification conducted provide sufficient support for the proposed use of the biomarker ${ }^{(13)}$. The overall aim of this review is to identify robust and predictive markers, or patterns or clusters of markers, that can be used to assess inflammation in human nutrition studies in the general population and to create a consensus for grading these biomarkers.

\section{How were the biomarkers chosen?}

In order to select likely biomarkers of relevance to nutrition studies, it was decided to first identify general and diseasespecific markers of inflammation within the circulation 


\section{N British Journal of Nutrition}

Table 3. Soluble peptides associated with inflammation

\begin{tabular}{|c|c|c|c|}
\hline $\begin{array}{l}\text { Soluble inflammatory } \\
\text { marker }\end{array}$ & $\begin{array}{l}\text { Main producing } \\
\text { cells/organs }\end{array}$ & Target/receptors (when relevant) & Biological function(s) \\
\hline \multicolumn{4}{|l|}{ Cytokines/chemokines } \\
\hline IL-1 $\beta$ & Immune cells & $\begin{array}{l}\text { IL-1R1 and IL-1R2 expressed mainly on leucocytes (also } \\
\text { hypothalamus) }\end{array}$ & $\begin{array}{l}\text { Fever, neutrophil attraction and activation, amino acid release by muscle, } \\
\text { collagen production by fibroblasts, B and T lymphocyte activation, acute- } \\
\text { phase protein synthesis by liver }\end{array}$ \\
\hline IL-6 & $\begin{array}{l}\text { Bone, endothelial, epi- } \\
\text { thelial, immune and } \\
\text { muscle cells }\end{array}$ & $\begin{array}{l}\text { Hepatocytes and leucocytes expressing IL-6R, i.e. } \\
\text { IL-6Ra/GP130 complex (also hypothalamus) }\end{array}$ & $\begin{array}{l}\text { Fever, acute-phase protein synthesis, amino acid release by muscle, fatty } \\
\text { acid release from adipose tissue, neutrophil and lymphocyte activation, } \\
\text { inhibition of TNF and IL-1 and activation of IL-1ra and IL-10 secretion }\end{array}$ \\
\hline IL-10 & Immune cells & $\begin{array}{l}\text { IL-10Ra (or IL-10R1) combined with IL-10R2 expressed by } \\
\text { innate and adaptive leucocytes }\end{array}$ & $\begin{array}{l}\text { Decreases pro-inflammatory cytokine expression, reduces Th17 generation, } \\
\text { reduces MHC class II and co-stimulatory molecule expression by anti- } \\
\text { gen-presenting cells, improves B-cell survival and antibody production }\end{array}$ \\
\hline $\begin{array}{l}\mathrm{IL}-12 \text { (IL-12A or } \\
\text { p35 + IL-12B or } \mathrm{p} 40 \\
\text { heterodimeric) }\end{array}$ & Immune cells & $\begin{array}{l}\text { IL-12R-b1 and IL-12R-b2 heterodimer expressed on leuco- } \\
\text { cytes (T and NK cells) }\end{array}$ & $\begin{array}{l}\text { Pro-Th1 and anti-Th2 function, Th1 and NK cell proliferation, stimulation of } \\
\text { T and NK cell cytotoxic activity, up-regulation of IL-18R, activation of } \\
\text { macrophages, anti-angiogenic }\end{array}$ \\
\hline IL-17A & $\begin{array}{l}\text { Immune cells (Th17 } \\
\text { cells) }\end{array}$ & $\begin{array}{l}\text { IL-17R (IL-17RA, IL-17RB and IL-17RC) expressed on } \\
\text { endothelial and epithelial cells as well as on keratinocytes, } \\
\text { fibroblasts and some leucocytes }\end{array}$ & $\begin{array}{l}\text { Potentiates chemokine and pro-inflammatory cytokine release, triggers anti- } \\
\text { microbial peptide secretion, clear role in skin protection against bacterial } \\
\text { and fungal infections, involved in allergic responses }\end{array}$ \\
\hline IL-18 & $\begin{array}{l}\text { Epithelial and immune } \\
\text { cells }\end{array}$ & $\begin{array}{l}\text { IL-18Ra (or IL-1Rrp) and IL-18Rb (or IL-18RAP) expressed } \\
\text { on leucocytes, endothelial and smooth muscle cells }\end{array}$ & $\begin{array}{l}\text { Induction of IL-1 } \beta \text {, IFN- } \gamma \text { and TNF production. In combination with IL-12 } \\
\text { suppresses Th2-mediated B-cell responses (IgE and IgG1 secretion) }\end{array}$ \\
\hline $\begin{array}{l}\text { IL-23 (IL-23A or } \\
\text { p19 + IL-12B or p40 } \\
\text { heterodimeric) }\end{array}$ & Immune cells & IL-12R-b1 and IL-23R heterodimer expressed on T cells & $\begin{array}{l}\text { Directs T-helper cell differentiation (Th17), induces IFN- } \gamma \text { and IL-12 } \\
\text { production }\end{array}$ \\
\hline IFN- $\gamma$ & $\begin{array}{l}\text { Epithelial and immune } \\
\text { cells }\end{array}$ & $\begin{array}{l}\text { IFNGR1 and IFNGR2 heterodimeric receptor expressed } \\
\text { mainly on APC but also on epithelial, NK and T cells }\end{array}$ & $\begin{array}{l}\text { NK cell and macrophage activation, stimulates expression of MHC I and II } \\
\text { on antigen-presenting cells, promotes Th1 differentiation, suppresses } \\
\text { Th2 differentiation, viral replication inhibition }\end{array}$ \\
\hline TNF & $\begin{array}{l}\text { Adipocytes, epithelial, } \\
\text { endothelial, immune } \\
\text { and muscle cells }\end{array}$ & $\begin{array}{l}\text { TNFR1 and TNFR2 expressed on a wide variety of cells and } \\
\text { organs (leucocyte, muscle, adipocytes, hypothalamus, } \\
\text { etc.) }\end{array}$ & $\begin{array}{l}\text { Fever, acute-phase protein synthesis, procoagulation, Th-cell differen- } \\
\text { tiation, cachexia, apoptosis, inhibits viral replication, antitumour activity, } \\
\text { induction of TNFR shedding as sTNFR }\end{array}$ \\
\hline $\begin{array}{l}\text { TNFR (TNFR1 and } \\
\text { TNFR2) }\end{array}$ & $\begin{array}{l}\text { Adipocytes, epithelial, } \\
\text { immune and muscle } \\
\text { cells }\end{array}$ & Binds TNF (which also induces its shedding) & $\begin{array}{l}\text { At high concentration inhibits TNF function (competition with membrane- } \\
\text { bound receptors). At low concentration, can stabilise TNF trimeric } \\
\text { structure and improve half-life of TNF }\end{array}$ \\
\hline $\begin{array}{l}\text { MIP-2 } \alpha(C X C L 2 ; \\
\text { GROb; GRO-2) }\end{array}$ & Immune cells & $\begin{array}{l}\text { CXCR2 expressed on neutrophils, mast cells, keratinocytes } \\
\text { and endothelial cells }\end{array}$ & Recruitment of leucocytes and haematopoietic stem cells \\
\hline IL-8 (CXCL8) & $\begin{array}{l}\text { Epithelial, endothelial } \\
\text { and immune cells }\end{array}$ & $\begin{array}{l}\text { CXCR1 and CXCR2 expressed on neutrophils, mast cells, } \\
\text { keratinocytes and endothelial cells }\end{array}$ & $\begin{array}{l}\text { Neutrophil (and basophil) attraction and activation to the site of } \\
\text { inflammation, angiogenic properties, stimulation of acute-phase } \\
\text { protein synthesis }\end{array}$ \\
\hline IP-10 (CXCL10) & $\begin{array}{l}\text { Epithelial, endothelial } \\
\text { and immune cells }\end{array}$ & $\begin{array}{l}\text { CXCR3-A or CXCR3-B expressed on activated T cells, NK } \\
\text { cells, epithelial and endothelial cells }\end{array}$ & $\begin{array}{l}\text { Recruitment/trafficking of leucocytes and promotion of adhesion to } \\
\text { endothelial cells. Expression largely controlled by IFN- } \gamma\end{array}$ \\
\hline MCP-1 (CCL2) & $\begin{array}{l}\text { Epithelial, endothelial } \\
\text { and immune cells }\end{array}$ & $\begin{array}{l}\text { CCR1 and CCR2 expressed on monocytes, macrophages, } \\
\text { dendritic cells and endothelial cells, as well as on some } \\
\text { lymphocyte subsets }\end{array}$ & $\begin{array}{l}\text { Leucocyte recruitment (monocytes, dendritic cells and memory cells); some } \\
\text { action on mast cell degranulation }\end{array}$ \\
\hline $\mathrm{MIP}-1 \alpha(\mathrm{CCL} 3)$ & Immune cells & $\begin{array}{l}\text { CCR1, CCR4 and CCR5 expressed on monocytes, macro- } \\
\text { phages, dendritic cells and endothelial cells mainly, as well } \\
\text { as on some lymphocyte subsets }\end{array}$ & Leucocyte recruitment (monocytes, B and T cells, as well as eosinophils) \\
\hline RANTES (CCL5) & $\begin{array}{l}\text { Epithelial, endothelial } \\
\text { and immune cells }\end{array}$ & $\begin{array}{l}\text { CCR1, CCR3, (CCR4) and CCR5 expressed on monocytes, } \\
\text { macrophages, dendritic cells and endothelial cells mainly, } \\
\text { as well as on some lymphocyte subsets and airway } \\
\text { epithelium }\end{array}$ & $\begin{array}{l}\text { Leucocyte recruitment (T cells, basophils and eosinophils), NK cell } \\
\text { activation. Highly expressed upon pro-inflammatory cytokine exposure }\end{array}$ \\
\hline \multicolumn{4}{|l|}{ Acute-phase proteins } \\
\hline C-reactive protein & Liver & Phosphatidylcholine residues & $\begin{array}{l}\text { Host defence (clearance of pathogens and dead cells) by opsonisation and } \\
\text { complement activation }\end{array}$ \\
\hline$\alpha-1$-Antitrypsin & Liver & Binds proteases such as elastase & Serpin protease inhibitor (tissue protection) \\
\hline
\end{tabular}




\section{N British Journal of Nutrition}

\begin{tabular}{|c|c|c|c|}
\hline $\begin{array}{l}\text { Soluble inflammatory } \\
\text { marker }\end{array}$ & $\begin{array}{l}\text { Main producing } \\
\text { cells/organs }\end{array}$ & Target/receptors (when relevant) & Biological function(s) \\
\hline von Willebrand factor & $\begin{array}{l}\text { Endothelial cells and } \\
\text { megakaryocytes }\end{array}$ & gp1b platelet receptor & Haemostasis/platelet adhesion/factor VIII carrier \\
\hline Serum amyloid $A$ & Liver & FPRL1, CD36, SR-BI/CLA-1, P2X7 and TLR & $\begin{array}{l}\text { Cholesterol transport, chemoattraction, opsonin, potentiates matrix metallo- } \\
\text { proteinase } 9 \text { activity, Th17 generation and pro-inflammatory cytokine } \\
\text { (IL-1 } \beta \text {, IL-6 and TNF) expression }\end{array}$ \\
\hline Fibrinogen & Liver & Thrombin substrate & Blood coagulation (conversion into fibrin by thrombin) \\
\hline$\alpha-1-$ Antichymotrypsin & Liver, also pancreas & $\begin{array}{l}\text { Binds and inactivates proteases such as cathepsin G or } \\
\text { chymase }\end{array}$ & Serpin protease inhibitor (tissue protection) \\
\hline Complement C3 & Liver & Bacterial surfaces & Innate defence (complement system activation) anaphylatoxin and opsonin \\
\hline Complement C4 & Liver & Complement R1, endothelium & Innate defence (complement system activation) anaphylatoxin and opsonin \\
\hline IL-1ra & $\begin{array}{l}\text { Adipocytes, epithelial } \\
\text { and immune cells }\end{array}$ & $\begin{array}{l}\text { IL-1R1 and IL-1R2 expressed mainly on leucocytes (also } \\
\text { hypothalamus) }\end{array}$ & Natural inhibitor of IL- $1 \alpha$ and IL-1 $\beta$ (competition for the same receptors) \\
\hline $\begin{array}{l}\text { Plasminogen activator } \\
\text { inhibitor-1 }\end{array}$ & $\begin{array}{l}\text { Adipocytes and endo- } \\
\text { thelial cells }\end{array}$ & tPA, uPA and matrix metalloproteinases are known targets & $\begin{array}{l}\text { Serine protease inhibitor (serpin) inhibiting tPA and uPA, leading to lower } \\
\text { plasminogen activation and hence reduction of fibrinolysis }\end{array}$ \\
\hline \multicolumn{4}{|l|}{ Adhesion markers } \\
\hline VCAM-1 (CD106) & Endothelial cells & Binds to integrins VLA-4 and $\alpha 4 \beta 7$ & $\begin{array}{l}\text { Adhesion of leucocytes to endothelial cells. Expression stimulated by } \\
\text { pro-inflammatory cytokines (IL-1 and TNF) as well as IL-4. Soluble form } \\
\text { displays lymphocyte chemotactic properties }\end{array}$ \\
\hline ICAM-1 (CD54) & $\begin{array}{l}\text { Epithelial, endothelial } \\
\text { and immune cells }\end{array}$ & $\begin{array}{l}\text { Binds to CD11a/CD18 (LFA-1) or CD11b/CD18 (MAC-1) } \\
\text { integrins }\end{array}$ & $\begin{array}{l}\text { Adhesion of leucocytes to endothelial cells or antigen-presenting cells. } \\
\text { Expression stimulated by pro-inflammatory cytokines (IL-1 and TNF). } \\
\text { Soluble form displays macrophage activation properties and reduction of } \\
\text { leucocyte adhesion to endothelium }\end{array}$ \\
\hline E-selectin (CD62E) & Endothelial cells & $\begin{array}{l}\text { Binds sialylated carbohydrates (Lewis A and Lewis X) on } \\
\text { leucocyte surface (glycoproteins and glycolipids). } \\
\text { Proposed molecules PSGL-1 and ESL-1 }\end{array}$ & $\begin{array}{l}\text { Adhesion/recruitment of leucocytes to endothelial cells. Expression stimu- } \\
\text { lated by pro-inflammatory cytokines (IL-1 and TNF). No clear specific } \\
\text { functions for soluble form }\end{array}$ \\
\hline P-selectin (CD62P) & $\begin{array}{l}\text { Endothelial cells and } \\
\text { platelets }\end{array}$ & $\begin{array}{l}\text { Binds sialylated carbohydrates (Lewis A and Lewis X) on } \\
\text { leucocyte surface (glycoproteins and glycolipids). Known } \\
\text { molecules PSGL-1 and CD24 }\end{array}$ & $\begin{array}{l}\text { Adhesion/recruitment of leucocytes to endothelial cells. Aggregation of } \\
\text { platelets. Expression stimulated by histamine and thrombin. No clear } \\
\text { specific functions for soluble form }\end{array}$ \\
\hline \multicolumn{4}{|r|}{ 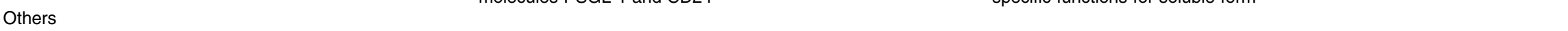 } \\
\hline Leptin & Adipocytes & Leptin $\mathrm{R}$ expressed by neurons in the hypothalamus & $\begin{array}{l}\text { Regulation of food intake (appetite), energy expenditure, adipose tissue } \\
\text { mass }\end{array}$ \\
\hline tPA & Endothelial cells & Interacts with plasminogen, fibrinogen, LRP1, neuroserpin & $\begin{array}{l}\text { Serine protease involved in fibrinolysis by enzymatic conversion of plasmi- } \\
\text { nogen into plasmin }\end{array}$ \\
\hline $\mathrm{sPLA}_{2}$ & Ubiquitous & Phospholipids are substrates & $\begin{array}{l}\text { Recognition and hydrolysis of } s n-2 \text { acyl-bound phospholipids releasing a } \\
\text { NEFA and a lysophospholipid. Sn-2 position often contains arachidonic } \\
\text { acid (important eicosanoid precursor). PAF precursor generation. } \mathrm{SPLA}_{2} \\
\text { has antimicrobial properties. IFN- } \gamma \text { is known to activate } \mathrm{SPLA}_{2}\end{array}$ \\
\hline Antimicrobial peptides & $\begin{array}{l}\text { Paneth cells and } \\
\text { immune cells }\end{array}$ & Bacteria and some viruses & Targeted microbe killing \\
\hline Autoantibodies & B cells and plasma cells & Self antigens (protein, DNA, lipids, etc.) & Cell/tissue destruction \\
\hline $\lg \mathrm{E}$ & B cells and plasma cells & $\begin{array}{l}\text { FceR1 and FceR2 expressed on basophils and mast cells } \\
\text { (plus other granulocytes and platelets) }\end{array}$ & $\begin{array}{l}\text { Defence against parasites and allergic reactions (allergen recognition } \\
\text { followed by mast cell degranulation and basophil secretion of Th2 } \\
\text { cytokines and pro-inflammatory mediators) }\end{array}$ \\
\hline \multicolumn{4}{|c|}{ 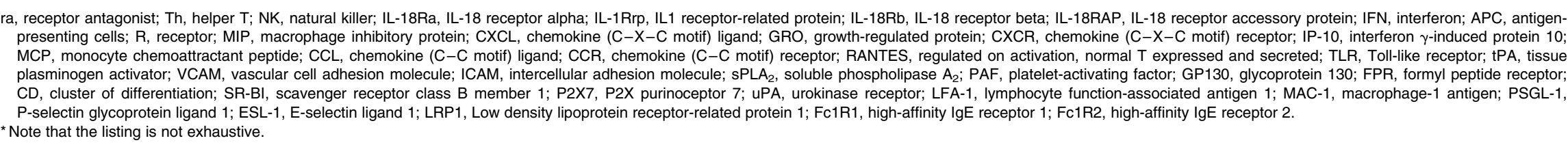 } \\
\hline
\end{tabular}


(i.e. soluble within plasma/serum or as circulating cells) and within tissue sites. These markers were identified by considering a range of conditions with a recognised inflammatory component elicited within different body compartments (i.e. adipose tissue, brain, gastrointestinal tract, vascular wall, joints, airways or skin). The objective of considering such a wide range of pathological conditions was to identify those markers that are common to inflammation, irrespective of its causative trigger. The following four general families of inflammatory disease are discussed herein: metabolic conditions (obesity, type 2 diabetes and cardiovascular disease (CVD)), immune-mediated inflammatory diseases (RA, Crohn's disease and psoriasis), allergic diseases (asthma and atopic dermatitis) and a prototypical neurodegenerative disease (Alzheimer's disease). These diseases each have different molecular triggers, which are mostly exogenous to the host individual but are endogenous in some cases. For each disease, Table 4 lists the plasma/ serum (hereafter termed soluble), blood cell and tissue markers of inflammation commonly reported in the literature related to that disease; the listing is not exhaustive.

Although inflammation-induced tissue damage occurs in an organ-specific manner (adipose tissue, vascular wall, joints, skin, gut, airways and brain) in the different diseases or conditions, there is some commonality among the responses and markers seen in the different organs (summarised in Tables 5 and 6 for soluble markers and blood cellular markers, respectively). Indeed, although triggers, localisation and resulting clinical symptoms are different, many of the processes, cells and molecules involved in the actual inflammatory response are remarkably similar. Most, if not all, of the chronic inflammatory diseases considered here are characterised by an increase in the number of leucocytes in the bloodstream and by overproduction and appearance in the bloodstream of increased concentrations of inflammatory cytokines (TNF, IL-1 $\beta$, IL- 6 and interferon- $\gamma$ ) and chemokines (IL-8 and monocyte chemoattractant protein (MCP)-1). Elevated levels of these mediators act to amplify the inflammatory process (e.g. by attracting further inflammatory cells to the site), contribute to tissue destruction, elicit systemic effects (e.g. hepatic CRP synthesis) and, in many cases, actually cause the clinical symptoms observed (Fig. 2; Table 4). Thus, a consideration of a wide range of inflammatory diseases affecting distinct sites within the body has enabled the identification of a set of 'common' or 'general' markers of inflammation that can be measured in the bloodstream (Tables 5 and 6). The selection of soluble markers of inflammation has focused on peptides and proteins; lipid mediators have not been considered further because of their instability and relative difficulty of measurement. For most of the soluble markers identified (Table 5), there is no commonly accepted normal range of concentrations. In contrast, for the blood cellular markers of inflammation (Table 6), there is a generally accepted normal range and some of these markers are used clinically.

In addition to the general, non-specific markers of inflammation identified above, there are a number of inflammatory markers that are more disease specific (Table 4). Sometimes these markers are present at the site of the inflammatory locus, such as thymic stromal lymphopoietin in skin lesions in atopic dermatitis. On other occasions, they may appear in the circulation (e.g. rheumatoid factor in RA). Because the aim of this evaluation of inflammatory markers is to identify those to be assessed in nutrition studies in the general population, disease-specific markers are not considered to be of relevance to this aim. Likewise, assessment of general, nonspecific inflammatory markers at sites of disease activity (e.g. cytokines in synovial fluid in RA, in bronchoalveolar lavage fluid in asthma, in skin lesions in psoriasis or in gut mucosa in Crohn's disease) was not considered relevant to the nondisease setting. For these reasons, inflammatory markers that are disease specific and assessment of inflammatory markers in tissues or lesions are not further considered here. Thus, this review is restricted to the consideration of inflammatory markers in the blood, either soluble markers in plasma/ serum (Table 5) or circulating cells (Table 6).

\section{Key messages}

(1) Acute inflammation is a normal physiological response critical to maintain homeostatic control, but when it becomes chronic, inflammation contributes to the pathophysiology of a range of diseases.

(2) Common soluble markers of inflammation include cytokines, chemokines, lipids, acute-phase proteins and adhesion molecules.

(3) Common blood cellular markers of inflammation include various subclasses of leucocytes. The same markers are involved in both acute and chronic inflammatory processes, meaning that the markers themselves, in isolation, cannot be used to distinguish the two processes.

\section{Modifiers of inflammatory markers}

There is a considerable between-individual variation in the numbers of leucocytes and of leucocyte subclasses and in the concentrations of the soluble markers of inflammation. There is no generally accepted 'normal range' for most of these markers, although there are clinically accepted normal ranges for total leucocytes and the leucocyte subclasses (Table 6). A number of modifiers, other than the presence of an inflammatory trigger, have been shown to influence the concentrations of these markers; these modifiers include age, body fatness, physical (in)activity, sex, genetics, smoking, gut microbiota composition, diet, use of medications and other factors such as emotional stress, pollution, viral infection and sleep behaviour (Fig. 3; Tables 5 and 6). These modifiers should all be considered when designing a study aimed at measuring inflammatory biomarkers.

\section{Influence of age}

A certain degree of inflammation may be part of adaptability and homeostasis in older people, and it has been demonstrated that their ability to mount a vigorous inflammatory 
Nes British Journal of Nutrition

Table 4. Markers associated with inflammation in specific diseases

\begin{tabular}{|c|c|c|c|c|c|c|c|c|c|}
\hline \multirow{2}{*}{$\begin{array}{l}\text { Example of } \\
\text { disease }\end{array}$} & \multicolumn{3}{|c|}{ Metabolic } & \multicolumn{3}{|c|}{ Autoimmune } & \multicolumn{2}{|c|}{ Allergic } & \multirow{2}{*}{$\begin{array}{l}\text { Neurodegenerative } \\
\text { Alzheimer's disease }\end{array}$} \\
\hline & Obesity & Type 2 diabetes & Cardiovascular & Rheumatoid arthritis & Psoriasis & Crohn's disease & Atopic dermatitis & Allergic asthma & \\
\hline $\begin{array}{l}\text { Key molecular } \\
\text { drivers of the } \\
\text { inflammatory } \\
\text { response }\end{array}$ & $\begin{array}{l}\text { Infiltration of macro- } \\
\text { phages into adi- } \\
\text { pose tissue in } \\
\text { response to meta- } \\
\text { bolic stress; gut } \\
\text { microbiota } \\
\text { (possibly) }\end{array}$ & $\begin{array}{l}\text { Infiltration of macro- } \\
\text { phages into adi- } \\
\text { pose tissue in } \\
\text { response to meta- } \\
\text { bolic stress }\end{array}$ & $\begin{array}{l}\text { Uptake of oxidised } \\
\text { LDL by macro- } \\
\text { phages in the } \\
\text { vessel wall; endo- } \\
\text { thelial injury }\end{array}$ & Unknown & $\begin{array}{l}\text { Skin streptococci } \\
\text { and unknown } \\
\text { host factors }\end{array}$ & $\begin{array}{l}\text { Gut microbiota and } \\
\text { unknown host } \\
\text { factors }\end{array}$ & $\begin{array}{l}\text { Allergens and other } \\
\text { irritants }\end{array}$ & $\begin{array}{l}\text { Allergens and other } \\
\text { irritants }\end{array}$ & $\begin{array}{l}\text { Modified and mis- } \\
\text { folded proteins }\end{array}$ \\
\hline Tissue markers & $\begin{array}{l}\text { Adipose tissue: } \\
\text { inflammatory cell } \\
\text { infiltrate } \\
\text { (especially macro- } \\
\text { phages), inflam- } \\
\text { matory gene } \\
\text { expression and } \\
\text { cytokine } \\
\text { expression }\end{array}$ & $\begin{array}{l}\text { Adipose tissue: } \\
\text { inflammatory cell } \\
\text { infiltrate } \\
\text { (especially macro- } \\
\text { phages), inflam- } \\
\text { matory gene } \\
\text { expression and } \\
\text { cytokine } \\
\text { expression }\end{array}$ & $\begin{array}{l}\text { Vessel wall or } \\
\text { plaque material: } \\
\text { macrophage and } \\
\text { T-cell infiltrate }\end{array}$ & $\begin{array}{l}\text { Synovial fluid: T } \\
\text { cells, macro- } \\
\text { phages, neutro- } \\
\text { phils, synovio- } \\
\text { cytes plus } \\
\text { inflammatory } \\
\text { mediators } \\
\text { (cytokines, } \\
\text { eicosanoids) }\end{array}$ & $\begin{array}{l}\text { Skin lesions: } \\
\text { Th1/Th17 cells, } \\
\text { some neutrophils, } \\
\text { activated kerati- } \\
\text { nocytes, IFN- } \gamma \text {, } \\
\text { VEGF, IL-17, } \\
\text { TNF, defensins }\end{array}$ & $\begin{array}{l}\text { Gut mucosa: cyto- } \\
\text { kines and chemo- } \\
\text { kines (TNF, IL-18, } \\
\text { IL-23, IFN- } \gamma, \\
\text { CXCL10), stress } \\
\text { markers (GRP78, } \\
\text { CPN60, PKR), } \\
\text { activated MAPK, } \\
\text { NF-kB, SMAD7; } \\
\text { faeces: calprotec- } \\
\text { tin, S100 proteins } \\
\text { (S100A12, } \\
\text { S100A8/A9) }\end{array}$ & $\begin{array}{l}\text { Skin lesions: T cells, } \\
\text { eosinophils, mast } \\
\text { cells, thymic stro- } \\
\text { mal lymphopoie- } \\
\text { tin, Th2-type } \\
\text { cytokines }\end{array}$ & $\begin{array}{l}\text { Sputum/bronchoal- } \\
\text { veolar lavage } \\
\text { fluid: leucocytes, } \\
\text { eosinophils, mast } \\
\text { cells, eosinophilic } \\
\text { cationic protein, } \\
\text { TNF, IL-4, IL-5, } \\
\text { IL-6, IL-8, IL-12, } \\
\text { IL-13, osteopon- } \\
\text { tin, eotaxin, } \\
\text { cysteinyl-LT, } \\
\text { PGD , tryptase; } \\
\text { exhaled NO; lung } \\
\text { function in } \\
\text { response to } \\
\text { indirect challenge, } \\
\text { e.g. cold air; } \\
\text { urine: eosinophilic } \\
\text { cationic protein, } \\
\text { LTE }_{4}, \text { PGD } \\
\text { metabolite }\end{array}$ & $\begin{array}{l}\text { Plaque: activated } \\
\text { microglia and } \\
\text { reactive astro- } \\
\text { cytes, inflamma- } \\
\text { tory proteins } \\
\text { including comp- } \\
\text { lement factors, } \\
\text { acute-phase pro- } \\
\text { teins, pro-inflam- } \\
\text { matory cytokines } \\
\text { and chemokines } \\
\text { (as in blood), } \\
\text { increased Aß42, } \\
\text { total tau; CSF: } \\
\text { low levels of } \\
\text { A } 442, \text { increased } \\
\text { phosphorylated } \\
\text { tau (P-tau181) }\end{array}$ \\
\hline $\begin{array}{l}\text { Blood cellular } \\
\text { markers }\end{array}$ & $\begin{array}{l}\text { Total leucocytes, } \\
\text { total neutrophils, } \\
\text { CD11b (granulo- } \\
\text { cytes), CD11c } \\
\text { and CD66b } \\
\text { (monocytes), } \\
\text { T cells }\end{array}$ & Total leucocytes & Total leucocytes & $\begin{array}{l}\text { Possibly low } T_{\text {reg }} \\
\text { numbers/function, } \\
\text { Th1- and Th2- } \\
\text { type cytokine } \\
\text { responses } \\
\text { skewed to Th1 }\end{array}$ & $\begin{array}{l}\text { Total leucocytes, } \\
\text { total neutrophils }\end{array}$ & $\begin{array}{l}\text { Total leucocytes, } \\
\text { total neutrophils, } \\
\text { Th1 and Th17 } \\
\text { cells, macro- } \\
\text { phages }\left(\mathrm{CD} 163^{+},\right. \\
\left.\mathrm{CD}^{+} 8^{+}, \mathrm{S}_{100^{+}}\right)\end{array}$ & $\begin{array}{l}\text { Total eosinophils, } \\
\text { Th1- and Th2- } \\
\text { type cytokine } \\
\text { responses } \\
\text { skewed to Th2 }\end{array}$ & $\begin{array}{l}\text { Total eosinophils, } \\
\text { Th1- and Th2- } \\
\text { type cytokine } \\
\text { responses } \\
\text { skewed to Th2 }\end{array}$ & $\begin{array}{l}\text { B cells (decreased), } \\
\text { decreased } \\
\text { expression of acti- } \\
\text { vation marker } \\
\text { CD69 and chemo- } \\
\text { kine receptors on } \\
\text { T cells, low per- } \\
\text { centage of naive } \\
\text { CD4 T cells }\end{array}$ \\
\hline $\begin{array}{l}\text { Soluble inflam- } \\
\text { matory } \\
\text { markers }\end{array}$ & $\begin{array}{l}\text { CRP, SAA, fibrino- } \\
\text { gen, cytokines } \\
\text { (TNF, IL-1, IL-1ra, } \\
\text { IL-6, IL-8, IL-17, } \\
\text { IL-18, TNFR, lep- } \\
\text { tin), chemokines } \\
\text { (CCL2, CCL3, } \\
\text { CCL5), vWF, } \\
\text { adhesion mol- } \\
\text { ecules (VCAM-1, } \\
\text { ICAM-1, E-selec- } \\
\text { tin, P-selectin), } \\
\text { PAl-1, C3, low } \\
\text { adiponectin }\end{array}$ & $\begin{array}{l}\text { CRP, SAA, fibrino- } \\
\text { gen, cytokines } \\
\text { (TNF, IL-1, IL-1ra, } \\
\text { IL-6, IL-8, IL-17, } \\
\text { IL-18, TNFR, lep- } \\
\text { tin), chemokines } \\
\text { (CCL2, CCL3, } \\
\text { CCL5), vWF, } \\
\text { adhesion mol- } \\
\text { ecules (VCAM-1, } \\
\text { ICAM-1, E-selec- } \\
\text { tin, P-selectin), } \\
\text { PAl-1, low adipo- } \\
\text { nectin }\end{array}$ & $\begin{array}{l}\text { CRP, SAA, fibrino- } \\
\text { gen, cytokines } \\
\text { (TNF, IL-1, IL-1ra, } \\
\text { IL-6, IL-8, TNFR), } \\
\text { chemokines } \\
\text { (CCL2), vWF, } \\
\text { adhesion mol- } \\
\text { ecules (VCAM-1, } \\
\text { ICAM-1, E-selec- } \\
\text { tion, P-selectin), } \\
\text { PAl-1, } \alpha-1 \text {-anti- } \\
\text { trypsin, sPLA, } \\
\text { NO }\end{array}$ & $\begin{array}{l}\text { Rheumatoid factor, } \\
\text { autoantibodies, } \\
\text { CRP, cytokines } \\
\text { (TNF, IL-1, IL-1ra, } \\
\text { IL-6, IL-17, IFN- }- \\
\text { TNFR) }\end{array}$ & $\begin{array}{l}\text { CRP, TNF, other } \\
\text { cytokines }\end{array}$ & $\begin{array}{l}\text { Antimicrobial and } \\
\text { autoantibodies, } \\
\text { CRP, cytokines } \\
\text { (TNF, IFN- } \gamma \text {, IL- } \\
\text { 1 } 1 \text {, IL-6, IL-10, IL- } \\
\text { 12, IL-17, IL-18, } \\
\text { IL-23), chemo- } \\
\text { kines (CCL2, } \\
\text { CCL3, CCL5, } \\
\text { CXCL2, CXCL8, } \\
\text { CXCL10) }\end{array}$ & $\begin{array}{l}\text { Total and allergen- } \\
\text { specific IgE }\end{array}$ & $\begin{array}{l}\text { Total and allergen- } \\
\text { specific IgE, cyto- } \\
\text { kines (Th2-type } \\
\text { dominated) and } \\
\text { chemokines }\end{array}$ & $\begin{array}{l}\text { CRP, TNF, IL-6, } \\
\text { antichymotrypsin, } \\
\text { C3, C4 }\end{array}$ \\
\hline
\end{tabular}

Th, helper T; IFN, interferon; VEGF, vascular endothelial growth factor; CXCL, chemokine (C-X-C motif) ligand; GRP, glucose-related protein; PKR, protein kinase R; SMAD, Intracellular proteins that transduce extracellular signals from TGF beta ligands; CPN, chaperone; MAPK, mitogen-activated protein kinase; LT, leukotriene; CRP, C-reactive protein; SAA, serum amyloid A; ra, receptor antagonist; R, receptor; CCL, chemokine (C-C motif) ligand; vWF, von Willebrand factor; VCAM, vascular cell adhesion molecule; ICAM, intercellular adhesion molecule; PAI, plasminogen activator inhibitor; sPLA $A_{2}$, soluble phospholipase $\mathrm{A}_{2}$; C, complement. 
Table 5. Soluble markers of inflammation and their associated modifying factors

\begin{tabular}{|c|c|c|c|c|c|c|}
\hline Marker & $\begin{array}{l}\text { Typical range reported } \\
\text { in healthy subjects }{ }^{*}\end{array}$ & $\begin{array}{l}\text { Association with } \\
\text { increasing age }\end{array}$ & $\begin{array}{l}\text { Association } \\
\text { with increasing } \\
\text { body fatness }\end{array}$ & $\begin{array}{l}\text { Association } \\
\text { with habitual } \\
\text { physical activity }\end{array}$ & $\begin{array}{l}\text { Association } \\
\text { with smoking }\end{array}$ & References \\
\hline \multicolumn{7}{|l|}{ Cytokines/chemokines } \\
\hline TNF & $0.75-5 \mathrm{ng} / \mathrm{l}$ & $\leftrightarrow / \uparrow$ & $\uparrow$ & $\downarrow / \leftrightarrow$ & $\uparrow$ & $18,19,22,55-57,77,110,133,301$ \\
\hline TNFRI and TNFRII & $400-700 \mathrm{ng} / \mathrm{l}$ & $\uparrow$ & $\uparrow$ & $\downarrow$ & & $24,25,55,64,302,303,304$ \\
\hline IL-6 & $0.4-1.4 \mathrm{ng} / \mathrm{l}$ & $\leftrightarrow / \uparrow$ & $\uparrow$ & $\downarrow$ & $\uparrow$ & $14,18,20,21,24,57,61,62,77,110,130-132,305-307$ \\
\hline IL-1 $\beta$ & $200-500 \mathrm{ng} / \mathrm{l}$ & $\leftrightarrow / \uparrow / \downarrow$ & $\uparrow$ & $\leftrightarrow$ & $\leftrightarrow$ & $18,19,21,60,110,301$ \\
\hline IL-8 & $2-10 \mathrm{ng} / \mathrm{l}$ & $\leftrightarrow / \uparrow$ & $\leftrightarrow / \uparrow$ & $\uparrow$ & $\leftrightarrow$ & $24,63,64,77,308,309,310$ \\
\hline IFN- $\gamma$ & $1-5 \mathrm{ng} / \mathrm{l}$ & $\uparrow$ & & & & 24 \\
\hline CCL2 & $200-400 \mathrm{ng} / \mathrm{l}$ & $\leftrightarrow / \uparrow$ & $\uparrow$ & & & $24,31,63,65,66,77$ \\
\hline CCL3 & $0.1-11.3 \mathrm{ng} / \mathrm{l}$ & $\uparrow$ & & & & 308,309 \\
\hline CCL5 & $20-50 \mathrm{ng} / \mathrm{ml}$ & $\uparrow$ & $\leftrightarrow$ & $\leftrightarrow$ & $\leftrightarrow$ & 308,309 \\
\hline \multicolumn{7}{|l|}{ Acute-phase proteins } \\
\hline CRP & $0.1-10 \mathrm{mg} / \mathrm{l} \dagger$ & $\uparrow$ & $\uparrow$ & $\downarrow$ & $\uparrow$ & $14,26,42,62,67,68,77,135,136,138,139,311,312$ \\
\hline SAA & $15-35 \mathrm{mg} / \mathrm{l}$ & $\uparrow$ & $\uparrow$ & & $\leftrightarrow / \uparrow$ & $42,141,256,313$ \\
\hline Fibrinogen & $1500-4000 \mathrm{mg} / \mathrm{l}$ & $\uparrow$ & $\uparrow$ & $\downarrow$ & $\uparrow$ & $14,20,28,135-137,139,140,314,315$ \\
\hline Von Willebrand factor & $5-15 \mathrm{mg} / \mathrm{l}$ & $\uparrow$ & $\uparrow$ & & & $316-320$ \\
\hline Antichymotrypsin & $300-460 \mathrm{mg} / \mathrm{l}$ & $\uparrow$ & & & & \\
\hline C3 & $1-3 \mathrm{mg} / \mathrm{l}$ & & $\uparrow$ & $\downarrow$ & $\uparrow$ & $321-325$ \\
\hline IL-1ra & $350-700 \mathrm{ng} / \mathrm{l}$ & $\uparrow$ & $\uparrow$ & & $\leftrightarrow$ & $14,21,25,58-60,326$ \\
\hline \multicolumn{7}{|l|}{ Soluble adhesion markers } \\
\hline VCAM-1 & $500 \mathrm{ng} / \mathrm{ml}$ & $\uparrow$ & $\uparrow$ & $\downarrow$ & & $29,30,57,70$ \\
\hline ICAM-1 & $175-200 \mathrm{ng} / \mathrm{ml}$ & $\uparrow$ & $\uparrow$ & $\downarrow$ & $\uparrow$ & $58,70-73,130,327$ \\
\hline E-selectin & $43-80 \mathrm{ng} / \mathrm{ml}$ & $\leftrightarrow$ & $\uparrow$ & $\downarrow$ & $\uparrow$ & $30,70,72-74,130,328$ \\
\hline P-selectin & $50-60 \mathrm{ng} / \mathrm{ml}$ & $\uparrow$ & $\uparrow$ & $\downarrow$ & & 57,71 \\
\hline \multicolumn{7}{|l|}{ Adipokines } \\
\hline Leptin & $10 \mathrm{ng} / \mathrm{ml}$ & $\leftrightarrow$ & $\uparrow$ & $\downarrow$ & $\leftrightarrow / \downarrow$ & $55,61,65,75,327,329$ \\
\hline Adiponectin & $5-15 \mathrm{mg} / \mathrm{l}$ & $\leftrightarrow / \uparrow$ & $\downarrow$ & $\uparrow$ & $\downarrow$ & $33,34,76-78,330$ \\
\hline
\end{tabular}

R, receptor; IFN, interferon; CCL, chemokine (C-C motif) ligand; CRP, C-reactive protein; SAA, serum amyloid A; C, complement; ra, receptor antagonist; VCAM, vascular cell adhesion molecule; ICAM, intercellular adhesion molecule; $\uparrow$, positive association; $\downarrow$, negative association; $\leftrightarrow$, no clear association.

*These values are based on groups of healthy subjects in studies published in scientific literature. These are therefore indicative of what could be expected in such populations.

† Values $>10 \mathrm{mg} / \mathrm{l}$ considered to be indicative of inflammation beyond 'low grade'. 
Table 6. Blood cellular markers of inflammation and their modifying factors

\begin{tabular}{llcllll}
\hline Marker & Normal range & $\begin{array}{l}\text { Association with } \\
\text { increasing age }\end{array}$ & $\begin{array}{l}\text { Association } \\
\text { with increasing } \\
\text { body fatness }\end{array}$ & $\begin{array}{l}\text { Association } \\
\text { with habitual } \\
\text { physical activity }\end{array}$ & $\begin{array}{l}\text { Association } \\
\text { with smoking }\end{array}$ & References \\
\hline Total leucocytes & $4-11 \times 10^{9} / 1$ & $\uparrow$ & $\uparrow$ & $\downarrow$ & $\uparrow$ & $16,17,53,89,128,129$ \\
Total neutrophils & $2-7.5 \times 10^{9} / 1$ & $\uparrow$ & $\uparrow$ & $\downarrow$ & $\uparrow$ & $17,54,245$ \\
Total T lymphocytes & $0.6-2.5 \times 10^{9} / 1$ & $\leftrightarrow$ & $\uparrow$ & $\uparrow$ & $\uparrow$ & $35,89,331$ \\
Total eosinophils & $0-0.4 \times 10^{9} / 1$ & $\uparrow$ & $\uparrow$ & $\uparrow$ & $\uparrow$ & $89,332,333$ \\
Total monocytes & $0.2-0.8 \times 10^{9} / 1$ & $\uparrow$ & $\uparrow$ & $\uparrow$ & $\downarrow$ & 89,335 \\
\hline
\end{tabular}

Up arrow, Positive association; Down arrow, Negative association; Double arrow, No clear association.

* Based on data reported in MacLennon \& Drayson ${ }^{(336)}$.

response is associated with enhanced survival ${ }^{(14)}$. On the other hand, inflammation is considered to play an important role in the loss of lean body mass and in progression towards frailty in older persons. Studies investigating a possible effect of age on inflammatory markers have generally adopted one of two approaches. The first has been to look for an association between age and the concentrations of markers of interest, whereas the second has been to compare marker concentrations between two or more groups of individuals of different ages. Studies have generally stratified populations and set arbitrary thresholds varying from ages $>60,65,70$ to $\geq 75$ years to identify aged individuals. These studies, for the most part, have suggested that ageing is accompanied by a low-grade chronic inflammatory state, clearly shown by twoto fourfold higher concentrations of serum levels of several inflammatory markers such as cytokines and acute-phase proteins in older persons ${ }^{(15)}$. Several studies have reported ageassociated increases in total leucocyte numbers ${ }^{(16,17)}$ and in soluble concentrations of soluble pro-inflammatory cytokines such as IL-1 ${ }^{(18,19)}$, IL-6 ${ }^{(14,18,20,21)}$ and $\operatorname{TNF}^{(22,23)}$, although this has not been seen in all studies ${ }^{(21,24)}$. Others have reported higher concentrations of IL-1 receptor antagonist ${ }^{(14,21,25)}$ and of TNF-receptors ${ }^{(24,25)}$ with increased age. In line with these findings, many studies have reported higher concentrations of downstream markers such as acute-phase proteins like $\mathrm{CRP}^{(14,26)}, \alpha 1$-acid glycoprotein ${ }^{(27)}$ and fibrinogen $(14,20,28)$ Fewer studies have addressed the relationship of ageing with chemokines and adhesion molecules, although in some studies, vascular cell adhesion molecule (VCAM)-1 ${ }^{(29,30)}$ and intercellular adhesion molecule (ICAM)-1 ${ }^{(30)}$ have been shown to have higher concentrations in older persons while E-selectin was not ${ }^{(30)}$. Similarly, there is some evidence that concentrations of MCP- $1^{(31)}$, plasminogen activation inhibitor- $1^{(32)}$ and adiponectin ${ }^{(33,34)}$ are increased with ageing.

Overall, these changes support a generally increased state of low-grade chronic inflammation in older people compared with younger adults. The more limited literature on blood cellular markers would support this contention, but indicates that numbers and proportions of leucocytes in the older people differ considerably depending on the state of health of the individual $^{(35)}$. Although older individuals have been reported to have increased total leucocytes, the increase in neutrophils, in particular, has been related to reduced survival in longitudinal studies, whereas total lymphocyte numbers are not significantly associated with survival ${ }^{(36)}$. However, within the total lymphocyte population, there may be decreased numbers of $\mathrm{B}$ cells and increased numbers of CD8 cells in older persons, which can also have an impact on survival and which to a great extent depend on microbiological exposures ${ }^{(37)}$.

It is recognised that ageing represents cumulative effects of exposure to various triggers such as diet, physical (in)activity and stress, as well as micro-organisms, over the lifetime, and it is hypothesised that failure of anti-inflammatory mechanisms to neutralise such inflammatory processes triggered continuously lifelong plays a role in low-grade chronic inflammation in older people ${ }^{(38)}$. Inflammatory markers in older persons may also be influenced by co-morbidity, medication use or malnutrition ${ }^{(39-43)}$. However, there are some indications that once co-morbidities are accounted for, inflammation is still associated with ageing ${ }^{(14,15)}$. A number of other factors that may affect and modulate circulating levels of inflammatory mediators alter with ageing, including body composition, physical (in)activity, sex hormone concentrations, gut microbiota, emotional stress and a poor social environment ${ }^{(44-48)}$. It is likely that in some studies, these confounders have not been considered when the effect of age on inflammation has been evaluated $^{(44-48)}$. Thus, it is challenging to dissect out the effect of ageing per se on inflammatory markers in humans and essentially impossible to exclude all residual confounding concomitant modifying factors and lifelong exposures. One possibility is to examine inflammatory markers in centenarians as a model of successful ageing. Low levels of the pro-inflammatory cytokine IL- 6 and high levels of anti-inflammatory cytokines such as IL-10 and transforming growth factor (TGF) have been noted in centenarians ${ }^{(49,50)}$, suggesting that these extremely old persons do not suffer the 'inflammaging' noted in many older persons who do not survive to 100 years of age or beyond.

\section{Influence of body fatness and fat distribution}

As stated earlier, white adipose tissue secretes cytokines and chemokines, and macrophage and T-cell infiltration is dramatically increased in the adipose tissue of obese humans ${ }^{(51)}$. Obesity is associated with a state of low-grade chronic inflammation. Total blood leucocyte numbers are positively associated with obesity and the metabolic syndrome ${ }^{(16,17,52-54)}$. Differential leucocyte counts indicate that neutrophils, but not monocytes or lymphocytes, account for this predictive potential ${ }^{(17)}$. There are higher concentrations 


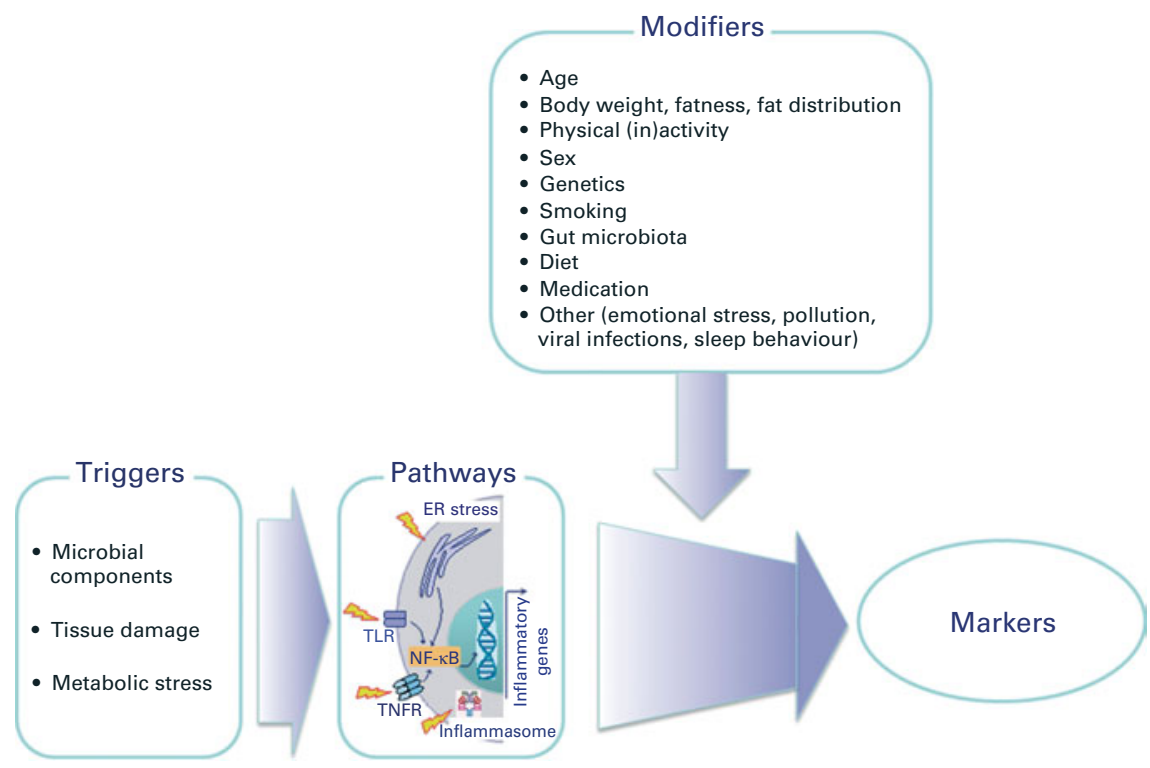

Fig. 3. Factors that influence the status of soluble and cellular markers of inflammation in the bloodstream. Triggers are those factors that can directly initiate an inflammatory response. Modifiers are endogenous and exogenous factors that may increase or decrease the response induced by a trigger. ER, endoplasmic reticulum; TLR, Toll-like receptor; TNFR, TNF receptor.

of circulating cytokines and chemokines such as $\mathrm{TNF}^{(55-57)}$, IL-1 ${ }^{(58-60)}$, IL-6 ${ }^{(57,61,62)}$, IL-8 ${ }^{(63,64)}$ and MCP-1 ${ }^{(63,65,66)}$ in obese individuals compared with normal-weight subjects. Several acute-phase proteins are elevated in overweight and obese subjects. For example, the circulating concentration of CRP is higher in obese persons, and obese subjects who lost weight showed decreased levels of $\mathrm{CRP}^{(67,68)}$. A meta-analysis showed a strong association between Body Mass Index (BMI) and serum amyloid A concentration ${ }^{(69)}$. Elevated levels of soluble adhesion molecules, such as VCAM-1, ICAM-1, E-selectin and P-selectin, are found in obese individuals compared with normal-weight subjects ${ }^{(57,70-74)}$. Leptin concentrations are higher in obese than in normal-weight subjects ${ }^{(55,61,65,75)}$, while adiponectin concentrations are lower in obese individuals ${ }^{(76-78)}$. Although these studies have focused on obesity per se, the distribution of adipose tissue appears to be important in determining inflammatory burden. Visceral adipose tissue has a greater production of inflammatory mediators such as cytokines than subcutaneous adipose tissue, although the precise contribution of each to the circulating pool is not clear ${ }^{(79)}$. Furthermore, other adipose tissue depots in so-called 'ectopic sites', such as within the liver, heart or skeletal muscle, may contribute to the production of inflammatory mediators even in the absence of obesity ${ }^{(80)}$. In this regard, the local production of inflammatory molecules by adipose tissue within the heart may be important; the amount of this tissue and its proximity to the coronary vessels could contribute to the development of coronary pathologies ${ }^{(81,82)}$. Although there has been considerable focus on the role of low-grade chronic inflammation in overweight, obesity and the metabolic syndrome $^{(6)}$, it is important to recognise that underweight also appears to be associated with low-grade chronic inflammation. For example, adolescent anorexia is associated with elevated levels of some inflammatory cytokines including TNF- $\alpha^{(83)}$, and low-grade chronic inflammation is associated with low body weight in older subjects ${ }^{(84)}$. Several proinflammatory cytokines, most notably $\mathrm{TNF}-\alpha$, have a causal role in cachexia ${ }^{(85)}$.

\section{Influence of physical (in)activity}

Physical (in)activity resulting in inadequate energy expenditure relative to intake may lead to the accumulation of visceral fat and consequently to the activation of inflammatory processes associated with this ${ }^{(86)}$. In contrast, physical activity promotes health and this may relate to the anti-inflammatory effect of regular exercise, which reduces visceral fat mass and induces an anti-inflammatory environment ${ }^{(87,88)}$. Subjects engaged in regular physical activity have lower blood leucocyte numbers ${ }^{(89)}$. Plasma concentrations of IL-6 are lower in individuals who undertake regular physical activity than in those who do not ${ }^{(90)}$. The lower concentrations of IL-6 in the circulation will subsequently result in lower CRP levels. Several studies of large population cohorts have provided evidence for an inverse, independent doseresponse relationship between the level of habitual physical activity and plasma CRP concentration in both men and women $^{(91-96)}$. Moreover, CRP levels in 2120 Finnish participants were associated with obesity indices (positively) and physical activity (inversely) among both sexes ${ }^{(97)}$. Cross-sectional studies have demonstrated that cardiorespiratory fitness levels are inversely associated with CRP concentrations and also the prevalence of elevated CRP concentrations ${ }^{(98)}$ However, conflicting findings exist and several training interventions have not produced changes in basal IL-6 or CRP levels ${ }^{(99-106)}$. There seems to be more consistency in patients with metabolic or coronary disease and in older individuals than in healthy or young people. In a relatively large intervention study of exercise training in cardiac rehabilitation patients, CRP concentration was reduced by $41 \%$, whereas 
CRP concentrations did not change in subjects who did not exercise $^{(107)}$. Rankovic et al. ${ }^{(108)}$ showed that 6 weeks of aerobic exercise can significantly reduce the inflammatory state by decreasing CRP and VCAM-1 levels in patients with stable coronary heart disease. One possible explanation could be that patients and older people have higher basal levels of inflammation before becoming physically active and physical activity is more effective in lowering the CRP levels in those with the highest initial CRP concentrations ${ }^{(107)}$. Given that physical activity and obesity are often inversely related, it is not clear as to whether the anti-inflammatory health benefits of a physically active lifestyle are due to exercise per se or result from favourable changes in body composition. A systematic review addressed whether fitness or fatness has the greatest impact on inflammatory factors ${ }^{(90)}$ and concluded that both fatness and the lack of fitness are associated with systemic inflammatory status, although the relative contributions of both may be dependent on age, disease status and sex. Different types of exercise to attain and maintain a state of physical fitness may have different effects on inflammation ${ }^{(109)}$, although this is little studied.

\section{Influence of sex}

Few studies have examined the effect of sex on inflammatory markers and the literature presents mixed findings. Some studies have reported no differences between males and females for most inflammatory markers examined, including TNF, TNF-receptor, IL-1, MCP-1 ${ }^{(24)}$ or IL-6 and ICAM-1 ${ }^{(29)}$. However, in a study of adolescents (aged 13 to 17 years), although CRP, C3 and C4 concentrations did not differ between girls and boys, adolescent boys had lower levels of adiponectin, leptin and L-selectin than girls, whereas girls had lower levels of ICAM-1, VCAM-1 and plasminogen activation inhibitor-1 than boys ${ }^{(86)}$. Some investigators have reported lower IL-1 $\beta$ levels in men ${ }^{(110)}$, whereas others ${ }^{(111)}$ have found that men have higher levels of IL-1 $\beta$-secreting monocytes than women. Importantly, few studies have reported on sex effects after adjusting for variables that can affect inflammatory markers, such as body fatness, fat distribution and physical (in)activity. Marques-Vidal ${ }^{(110)}$ showed in a Swiss population-based sample that males have higher levels of IL-6 and TNF and slightly but significantly lower levels of CRP when compared with females in crude analysis and after adjusting for age, BMI, smoking status and leisuretime physical activity in multivariate analysis. There is a need for further population-based studies in healthy adults to examine sex differences in inflammatory markers taking into account potential important confounders.

\section{Influence of genetics}

Both epigenetic and genomic variations influence the extent of the response of an inflammatory marker to a given trigger. Epigenetics refers to chemical modifications to chromatin or DNA that influence gene expression but are not encoded in the DNA sequence itself. The two major epigenetic mechanisms are the post-translational modification, often acetylation, of histone proteins in chromatin and the methylation of DNA itself. DNA methylation occurs at $\mathrm{CPG}$ sites of the gene sequence. Epigenetic variations appear to play an important role in determining the risk of inflammatory disorders ${ }^{(112-114)}$. Differences in the methylation status of $\mathrm{CpG}$ sites have been observed in key inflammatory response genes and influence the expression of those genes ${ }^{(115)}$. This is an area in which there are likely to be major advances in the next few years. It is important to note that epigenetic modifications are not fixed but may be modified by a number of different exposures, including stress hormones, oxidative stress, pollution and diet. This may partly explain the ability of those factors to act as modifiers of the inflammatory response.

SNP are variations in the DNA sequence at a single nucleotide that occur in at least $1 \%$ of the population. They can occur in both coding and non-coding regions of the genome. It is estimated that the human genome contains 3 million SNP. Genotype is a description of the allele pair present at a given site in the genome, and typically there will be three possible genotypes (e.g. AA, AG and GG). There are variations in allele frequencies and genotypes among different human populations because certain alleles and genotypes may have offered an evolutionary advantage in one geographical region and not in another. SNP within a coding sequence do not necessarily change the amino acid sequence of the protein that is produced, because of the degeneracy of the genetic code. SNP that are not in protein-coding regions may affect transcription factor binding or gene splicing or the sequence of non-coding RNA and, as a result, the gene expression, and hence the level of the encoded protein may differ among individuals with different genotypes. It is likely that SNP occur in regions of the genome associated with each of the inflammatory proteins being considered here (e.g. cytokines, chemokines, adhesion molecules, acutephase proteins), encoding enzymes responsible for the synthesis of non-peptide inflammatory mediators (e.g. in cyclooxygenase and lipoxygenase enzymes, NADPH oxidase and inducible NO synthase) and encoding regulatory proteins such as transcription factors. In addition, such genetic variations underlie the huge number of possible variants in the human leucocyte antigens involved in antigen presentation. This variation in possible human leucocyte antigens allows an individual to have the potential to deal with an enormous number of possible antigens that may be encountered. However, some human leucocyte antigens variants have strong associations with inflammatory diseases, such as human leucocyte antigens-DR4 with RA. A number of SNP are of functional significance, meaning that individuals with different genotypes will produce different levels of a particular inflammatory mediator in response to a given stimulus or trigger than other individuals ${ }^{(116-119)}$. Thus, genotype can influence the plasma concentration of inflammatory markers ${ }^{(116,120,121)}$. For example, the $\mathrm{G}$ to $\mathrm{C}$ polymorphism at the -174 position of the $I L-6$ gene has been reported to significantly influence plasma IL-6 concentrations: mean concentrations ( $\mathrm{pg} / \mathrm{ml})$ after adjusting for age, BMI, sex and smoking were 2.74 for GG homozygotes, 2.64 for heterozygotes and 1.63 for CC homozygotes $^{(116)}$. Similarly, the polymorphism at the +252 
position of the TNF- $\beta$ gene significantly affected plasma TNF concentrations in patients with sepsis: median concentrations (pg/ml) were approximately 200 for B1 homozygotes, 250 for heterozygotes and 600 for $\mathrm{B} 2$ homozygotes ${ }^{(120)}$. The genotype of certain inflammatory genes has been associated with the risk or severity of outcome in inflammatory disease ${ }^{(122,123)}$, infectious disease $\mathrm{s}^{(123,124)}$ and cancer ${ }^{(123,125)}$.

Ethnicity is related to genetic variation. The concentrations of some inflammatory markers have been shown to differ among ethnic groups ${ }^{(126)}$ and the prevalence of many of the common inflammatory diseases differs according to ethnicity. However, in addition to genetics, ethnic groups often differ in a number of the other modifying factors, which may contribute to the observed differences in inflammatory markers. In a systematic review and meta-analysis involving 221287 people from eighty-nine studies, median CRP concentrations were $2 \cdot 60$ (95\% CI 2.27, 2.96), $2 \cdot 51$ (95\% CI 1.18, 2.86), $2 \cdot 34$ (95\% CI 1.99, 2.80), 2.10 (95\% CI 1.77, 2.30) and $1.01(95 \%$ CI $0.88,1.18) \mathrm{mg} / \mathrm{l}$ in African Americans, Hispanics, South Asians, Caucasians and East Asians, respectively ${ }^{(127)}$. The differences among groups were retained after adjusting for age and BMI.

\section{Influence of smoking}

Cigarette smoke contains a variety of oxidant molecules in high amounts, inducing a strong oxidative stress in the smoker. In turn, oxidative stress can induce an inflammatory response $^{(1)}$. Indeed, it has been established in several population-based studies that smoking is associated with a low-grade chronic inflammatory state, as shown by higher blood leucocyte numbers ${ }^{(128,129)}$ and higher circulating concentrations of acute-phase proteins and cytokines. Several studies have reported elevated circulating concentrations of proinflammatory cytokines such as IL-6 ${ }^{(130-132)}$ and $\operatorname{TNF}^{(133,134)}$ in smokers compared with non-smokers. A number of studies have reported that $\mathrm{CRP}$ and fibrinogen concentrations are higher in smokers than in non-smokers ${ }^{(135-140)}$. CRP and fibrinogen concentrations are found to correlate significantly with the years of smoking, even after smoking cessation. In the Multinational MONItoring of trends and determinants in CArdiovascular disease (MONICA) study, for example, CRP concentrations were still elevated 10 years after quitting smoking ${ }^{(136)}$. Some adhesion molecules are also increased in the serum of smokers compared with non-smokers, including ICAM-1, P-selectin and E-selectin ${ }^{(130,141)}$. Taken as a whole, these are strong data supporting that smoking is associated with low-grade chronic inflammation. Fewer studies have investigated the impact of long-term passive smoking in nonsmokers on inflammatory markers; those studies that have been published present inconsistent findings. In a recent study on 200 non-smoking US truck industry workers, no statistically significant association was found between chronic exposure to second-hand smoke and systemic inflammatory markers such as IL-6, CRP or ICAM- $1^{(142)}$. Furthermore, in 7600 never-smoking adults included in National Health and Nutrition Examination Survey (NHANES) III, no significant association was found between CRP and second-hand smoke exposure, measured as serum cotinine level; however, fibrinogen was significantly higher in subjects with detectable but low cotinine levels ${ }^{(143)}$. However, in another study conducted on 5000 older British non-smoking subjects, serum cotinine level was positively associated with CRP, fibrinogen, von Willebrand factor and tissue plasminogen activator ${ }^{(144)}$.

\section{Influence of gut microbiota}

Humans co-evolved with gut microbes, which represent more than 3 million genes from several hundreds of bacterial species. There is evidence that the nature of the gut microbiota influences inflammatory processes, particularly within the gastrointestinal tract, but perhaps also systemically ${ }^{(145-149)}$. Thus, in animal models of IBD, disease initiation strongly depends on the presence of commensal bacteria and, conversely, in germ-free animals, IBD hardly develops ${ }^{(150,151)}$ In support of this, human studies have revealed that dysbiosis (gut microbiota alteration) is a common feature in patients with IBD in which the overall bacterial diversity is reduced and species belonging to the phyla Actinobacteria and Proteobacteria are over-represented ${ }^{(151-154)}$ while the phylum Firmicutes is reduced, especially Faecalibacterium prausnitzii, which has anti-inflammatory properties ${ }^{(155,156)}$. However, it is still unclear whether these changes are responsible for causing disease or are a result of other changes in the gut environment that result from inflammatory reactions and mucosal tissue damage. Nonetheless, some recent studies have reported positive effects of using probiotics, prebiotics and their combination (termed synbiotics) in IBD by a restoration of a healthy gut microbiota ${ }^{(157,158)}$. This suggests that there is potential for treating IBD through microbiota manipulation and modifications of interactions with the gut immune system. These findings provide a rationale for microbial characterisation in many other inflammatory diseases, such as psoriasis and allergic asthma. As in IBD, specific alterations of skin and airway microbiota are observed in patients with inflammatory diseases manifested at these sites ${ }^{(159-164)}$. More recently, gut microbiota in atopic dermatitis and in obese people has also been carefully addressed and a specific profile was found, indicating that gut commensals may also exert remote effects ${ }^{(145,165,166)}$. However, the precise causal role and the mechanisms involved remain to be established. Recent findings have also suggested that gut microbiota is a factor in metabolic diseases, as reviewed recently ${ }^{(167,168)}$. It has been demonstrated that the gut microbial profile is specific to the metabolic phenotype in mice and humans (i.e. obese $v$. lean and diabetic $v$. healthy). However, a clear demonstration connecting intestinal microbiota to metabolic diseases remained absent until recently. Indeed, Serino et al. ${ }^{(169)}$ showed that diabetic mice fed a high-fat diet and that developed diabetes display a specific alteration of gut microbiota with increased gut paracellular permeability leading to higher endotoxaemia and subsequent systemic low-grade inflammation and metabolic syndrome. Conversely, mice under the same feeding protocol that did not develop disease had no gut microbiota alteration ${ }^{(169,170)}$. The same specific gut microbiota alterations have also been reported in obese $v$. lean 
human subjects (reduced global diversity and relative increase in the ratio of Bacteroidetes:Firmicutes). F. prausnitzii was reduced in obese diabetic subjects compared with lean controls and was negatively correlated with serum levels of circulating inflammatory markers such as CRP and IL-6 in these subjects ${ }^{(171)}$. These changes affect the metabolic potential of the gut microbiota and support an increased capacity to harvest energy from the diet in obese people $e^{(172-174)}$. These features of obesity are transmissible as faecal material transfer from obese human adults to germ-free mice resulted in higher total body fat accumulation over time in contrast to lean human adult faecal material transfer ${ }^{(172-174)}$.

\section{Influence of diet}

The influence of diet on soluble markers of inflammation in different contexts has been described in detail elsewhere ${ }^{(1,6)}$ and will not be considered further here.

\section{Influence of medication}

It is obvious that whether specific or non-specific to particular disease processes and pathways or to a particular disease, pharmacologic treatment of inflammation is bound to greatly influence biomarker levels. A classic example is the influence of corticosteroids in autoimmune, allergic or mucosal inflammatory conditions; corticosteroids are powerful modifiers of cytokines and growth factors that influence other biomarkers such as CRP levels in RA and eosinophil levels in asthma. Indeed, such biomarkers are valuable in monitoring therapeutic responses and adherence to treatment. Selective treatments such as targeted biologics (e.g. anti-TNF therapy in inflammatory joint and bowel diseases) can also influence biomarkers and, again, these may be used to monitor therapy. It is, therefore, of utmost importance when using biomarkers for clinical decision making that any concurrent therapy that may influence their level or expression is taken into account.

\section{Influence of other modifiers}

In addition to the modifiers already considered, inflammatory biomarkers may be influenced by emotional stress ${ }^{(175-177)}$, exposure to pollution ${ }^{(178)}$ and sleep behaviour ${ }^{(179)}$ among other factors.

\section{Summary}

Among non-diseased individuals, the concentrations of the soluble markers and the numbers of some of the cellular markers of inflammation are altered with increasing age, body fatness and physical (in)activity, and are modified by genetics, smoking status, gut microbiota and medication use among other factors (Fig. 3). Typically, a number of the panel of inflammatory markers identified are altered in the same direction in response to a given modifying factor (Tables 5 and 6). Thus, there is little specificity in the inflammatory markers whose concentrations are changed during inflammatory states or which are sensitive to modifying factors. Thus, it is not possible to identify a single marker, or even a small number of markers, to define inflammation and to use as a target or targets in studies evaluating nutritional interventions. Therefore, it is likely to be important to identify patterns or clusters of markers that provide an inflammatory signature; it would seem likely that these patterns or clusters would include at least some of the individual markers considered here so far.

\section{Key messages}

(1) There are a number of endogenous and exogenous modifiers that influence the levels of inflammatory markers resulting in significant between-individual variation.

(2) These modifiers include age, body fatness, physical (in)activity, sex, genetics, smoking habits, diet, the composition of the gut microbiota and the use of certain medications.

(3) These modifiers should be recognised, and, where possible, controlled for, when nutrition studies are designed.

\section{Challenge models}

\section{Why challenge models are relevant}

The forgoing discussion has focused on individual markers of inflammation typically measured in the blood of individuals in the resting (e.g. fasting) state. Such measurements may differentiate between those individuals with an overt inflammatory disease and those without, and may also indicate the effects of influencing factors such as age, body fatness, physical (in)activity, genetics, smoking habit and the composition of the gut microbiota on chronic inflammatory tone. However, such measurements provide little information about an individual's (acute) inflammatory response to a challenge. It has been suggested that dynamic responses to challenges provide a more sensitive and meaningful indication of health ${ }^{(180,181)}$. More specifically, the dynamic inflammatory responses to a physiological challenge may provide a better (more relevant, sensitive, better interpretable) indicator of the impact of nutrition on inflammatory homeostasis and thus on the control of (acute) inflammatory responsiveness. Currently, relatively little is known about inflammatory markers after wellcontrolled acute challenges and whether these can be used to assess the effect of nutritional interventions on acute and/ or chronic inflammation. It is also not known what exactly constitutes an optimal inflammatory response to a challenge. This will need to be established by comparing standardised responses with challenges in different (sub)populations and by exploring their predictive value in prospective cohort studies. Despite these current gaps in knowledge, assessment of inflammatory resilience after experimental pro-inflammatory challenges is increasingly being studied. This section describes the inflammatory challenges that have been used to date and makes conclusions about their utility with regard to human studies involving nutritional interventions. A range of challenges that induce an acute inflammation was identified from the literature (Table 7 ). These challenges can be 
clustered according to the dominant stress triggering the inflammatory response: metabolic stress or metabolic overload (oral glucose load and oral lipid load); infection stress (injection of pro-inflammatory stimuli such as lipopolysaccharide (LPS), TNF or IL-6; early response to (adjuvants in) vaccines; or delayed-type and contact hypersensitivity responses); or tissue damage (acute exercise or exposure to UV radiation). Typically, the same inflammatory mediators as described previously (e.g. TNF, IL-6, CRP) have been used to follow the dynamic inflammatory response to the different challenges used (Table 7).

\section{Metabolic stress}

Oral glucose challenge. The oral glucose tolerance test (OGTT) is commonly used to test for insulin resistance and diabetes. After an overnight fast, a standardised drink containing glucose is given and subsequent blood glucose and sometimes blood insulin responses are assessed. There are some variations in the details of the protocol used ${ }^{(182,183)}$, but $75 \mathrm{~g}$ $(1255 \mathrm{~kJ}(300 \mathrm{kcal}))$ of glucose are typically given as a standardised drink in accordance with the recommendations of the World Health Organization (WHO) ${ }^{(184)}$. The oral glucose load induces a transient inflammatory response, which has been assessed in several studies as levels of circulating cytokines. Levels of CRP and IL-6 consistently increase, peaking after 1 and $2-4 \mathrm{~h}$, respectively ${ }^{(185-190)}$. Responses of TNF seem to be more variable. Several studies have described increases in markers of vascular inflammation such as ICAM$1^{(191)}$, VCAM-1 and E-selectin, peaking about $2 \mathrm{~h}^{(186)}$. Most markers normalise $3-4 \mathrm{~h}$ after the OGTT, but responses tend to be extended and/or stronger in obese, insulin-insensitive and type 2 diabetic patients ${ }^{(190)}$.

Oral fat challenge. Testing responsiveness to an oral challenge with fat is sometimes referred to as the oral fat tolerance test. However, unlike the test (OFTT), this is not an established diagnostic test with a standardised WHO-recommended protocol. Quality (fatty acid composition) and quantity of the fat have differed between studies. The fat is provided as a bolus (e.g. 200-350 $\mathrm{ml}$ whipping cream) in some studies, whereas it is provided as a high-fat meal in other studies (e.g. 50-75 g fat as part of a meal). Most studies have focused on the effects of the OFTT on fatty acid handling, but the effects on markers of (vascular) inflammation have also been described. Postprandial lipaemia as induced by the OFTT is associated with a transient increase in markers of (vascular) inflammation, but the size and kinetics of these responses are quite variable between studies, undoubtedly due in part to the different protocols used. It has been suggested that the responses differ between healthy individuals and the obese as well as those with type 2 diabetes ${ }^{(57,192)}$ and are sensitive to modulation by pharmaceutical, lifestyle and dietary interventions ${ }^{(185-190,193)}$. The response has typically been followed in terms of plasma concentrations of cytokines, such as TNF, IL-1 $\beta$, IL-6 and IL-8, soluble adhesion molecules, such as VCAM-1 and ICAM-1, and, in some cases, circulating levels of endotoxin over the period up to $3-6 \mathrm{~h}$ following the fat challenge.

\section{Infection stress}

Challenge with endotoxin or inflammatory mediators. Inflammatory cascades following intravenous administration of endotoxin (bacterial endotoxin; LPS), IL-6, TNF or hydrocortisone have been studied in quite some detail, mainly in the context of understanding septic shock responses. These studies varied widely with respect to subjects, dosing and sampling regimens used, but similar response patterns emerge (Fig. 4) ${ }^{(194-198)}$. Following intravenous administration of LPS, there is an initial increase in TNF and IL-1 peaking about $2 \mathrm{~h}$, a rise in IL- 6 reaching its maximum about $3 \mathrm{~h}$, followed by increases in IL- 8 and anti-inflammatory factors such as TNF-receptor, IL-1 receptor antagonist and IL-10 that plateau between 3 and $6 \mathrm{~h}$. However, it should be noted that these are very invasive challenges that can only be done in a clinical setting and their application in nutrition studies therefore seems less feasible.

Early response to (the adjuvant component of) vaccines. Effects of vaccination are primarily studied in relation to enhancing vaccination efficacy and are evaluated according to the level of protective antibody levels. However, innate immune factors including pro-inflammatory cytokines are induced during the (early) response to vaccination. These early responses are probably induced by the adjuvants used rather than by the antigen that is provided in the vaccine. Even though early responses to vaccination have not been studied extensively, several studies have indicated that enhanced levels of pro-inflammatory cytokines can be detected in serum post-vaccination. These studies have, however, been performed in different study populations, with different vaccines using different adjuvants (although the seasonal influenza vaccine has been used frequently), and serum samples have been evaluated at different time points after vaccination, ranging from $2 \mathrm{~h}$ to several weeks. Even so, in six of seven studies, IL-6 was increased after vaccination. This occurred $2-3 \mathrm{~h}$ after vaccination $^{(199)}$, but could also be detected after 1 or $2 \mathrm{~d}^{(200,201)}$ or even after several weeks ${ }^{(202)}$. In contrast, no change in IL-6 2 weeks after vaccination was noted by Glaser et $a l .{ }^{(203)}$. TNF was not increased $3 \mathrm{~h}$ after vaccination in a single study ${ }^{(204)}$, and CRP was increased in three vaccination studies ${ }^{(200,201,205)}$. Other markers that have been described to increase after vaccination are MCP-1, eotaxin and IL-13 ${ }^{(206)}$, as well as IL-2, IL-12 and IL-15 ${ }^{(207)}$. As noted for other challenge models, in some studies, it was clear that individuals with pre-existing conditions (inflammatory, stress, depression or age-related IL- 6 increase) had more prominent pro-inflammatory cytokine responses than the controls in the same studies ${ }^{(199-207)}$. These findings have indicated that pro-inflammatory cytokine levels can be measured after vaccination; however, more studies are needed to standardise a vaccination approach as an inflammatory challenge. Feasibility is expected to be high, and the responses noted seem quite reproducible, suggesting that most persons tested will indeed respond by the production of pro-inflammatory mediators. Using vaccination as an inflammatory challenge could be relevant to identify anti-inflammatory effects of nutritional intervention. An added advantage is that protective 
Table 7. Challenge models that may be used to study an inflammatory response and their features

\begin{tabular}{|c|c|c|c|c|c|c|c|}
\hline Challenge & Variability in design & Affected by & Effect on $\mathrm{TNF}^{\star}$ & Effect on IL-6* ${ }^{*}$ & $\begin{array}{l}\text { Effect on } \\
\text { CRP* }^{*}\end{array}$ & Effect on other mediators ${ }^{*}$ & References \\
\hline Oral glucose load & $\begin{array}{l}\text { Modest (dose, time points, mar- } \\
\text { kers) }\end{array}$ & Obesity, T2D & $\begin{array}{l}\leftrightarrow \text { to } \uparrow(2- \\
4 \mathrm{~h})\end{array}$ & $\uparrow(2-4 \mathrm{~h})$ & $\uparrow(1 \mathrm{~h})$ & $\uparrow$ Soluble adhesion molecules & $185-190$ \\
\hline Oral fat load & $\begin{array}{l}\text { High (amount and type of fat, } \\
\text { time points, markers) }\end{array}$ & Obesity, T2D & $\leftrightarrow$ to $-\uparrow(6 \mathrm{~h})$ & $\begin{array}{l}\leftrightarrow \text { to } \uparrow \\
\quad(6-8 h)\end{array}$ & $\leftrightarrow$ to $\uparrow(6 h)$ & $\begin{array}{l}\uparrow \text { Soluble adhesion molecules, } \\
\text { chemokines, cytokines (IL-8) }\end{array}$ & $\begin{array}{l}185,187 \\
\quad 188,193\end{array}$ \\
\hline Acute exercise & $\begin{array}{l}\text { High (duration and intensity of } \\
\text { exercise, physical fitness, } \\
\text { markers) }\end{array}$ & $\begin{array}{l}\text { Age, physical fitness, pre- } \\
\text { sence of inflammatory } \\
\text { disease }\end{array}$ & $\leftrightarrow$ to $\uparrow$ & $\leftrightarrow$ to $\uparrow$ & $\leftrightarrow$ to $\uparrow$ & $\uparrow$ Leucocytes, granulocytes & $\begin{array}{l}217-220 \\
223-226 \\
337\end{array}$ \\
\hline $\begin{array}{l}\text { Intravenous adminis- } \\
\text { tration of LPS, TNF } \\
\text { or IL-6 }\end{array}$ & $\begin{array}{l}\text { High (type and dose of trigger, } \\
\text { subjects, time points, } \\
\text { markers) }\end{array}$ & & $\uparrow(2 \mathrm{~h})$ & $\uparrow(2-3 h)$ & $\uparrow(24 \mathrm{~h})$ & $\begin{array}{l}\uparrow \text { Cortisol }(4 \mathrm{~h}), \text { noradrenaline } \\
(2 \mathrm{~h}), \\
\text { fever }(4 \mathrm{~h})\end{array}$ & $300,338,339$ \\
\hline UVB exposure & $\begin{array}{l}\text { High (type, dose and surface } \\
\text { area of irradiation, time points, } \\
\text { location) }\end{array}$ & $\begin{array}{l}\text { UV dose (duration, wave- } \\
\text { length), skin type }\end{array}$ & $\begin{aligned} \leftrightarrow & \text { (systemic) } \\
& \uparrow(6-12 \mathrm{~h}) \\
& (\text { local })\end{aligned}$ & $\begin{aligned} \leftrightarrow & \text { (systemic) } \\
& \uparrow(6-12 \mathrm{~h}) \\
& (\text { local })\end{aligned}$ & & $\begin{array}{l}\uparrow \mathrm{IL}-8(6-12 \mathrm{~h}) \uparrow \mathrm{IL}-4, \mathrm{IL}-10 \\
\text { (12-24h), erythema, local } \\
\text { eicosanoids }\end{array}$ & $231-234$ \\
\hline Vaccination & $\begin{array}{l}\text { High (different vaccines, differ- } \\
\text { ent study populations, time } \\
\text { points) }\end{array}$ & $\begin{array}{l}\text { Adjuvant used, CHD, } \\
\text { depression, stress, } \\
\text { T2D, age }\end{array}$ & $\leftrightarrow 3 \mathrm{~h}$ & $\begin{array}{l}\leftrightarrow \text { to } \uparrow(2 \mathrm{~h} \text { to } \\
\text { several } \\
\text { weeks) }\end{array}$ & $\uparrow(48 \mathrm{~h})$ & $\begin{array}{l}\uparrow \text { CCL2, eotaxin, IL-13, IL-2, } \\
\text { IL-12, IL-15, total leucocytes, } \\
\text { lymphocytes and monocytes } \\
\text { (1 month) }\end{array}$ & 199-207, 340 \\
\hline $\begin{array}{l}\text { Skin text (DTH, con- } \\
\text { tact sensitisation) }\end{array}$ & High (antigens/allergens) & $\begin{array}{l}\text { Sensitisation, age, } \\
\text { exercise }\end{array}$ & $\begin{array}{l}\text { No detectable } \\
\text { systemic } \\
\text { effects }\end{array}$ & & & Induration & 214,215 \\
\hline
\end{tabular}

CRP, C-reactive protein; T2D, type 2 diabetes; LPS, lipopolysaccharide; CCL, chemokine (C-C motif) ligand; DTH, delayed-type hypersensitivity; $\uparrow$, positive association; $\downarrow$, negative association; $\leftrightarrow$, no clear association. *Times indicated in parentheses are the approximate times of the maximal plasma concentration of the marker. 
Cytokine response

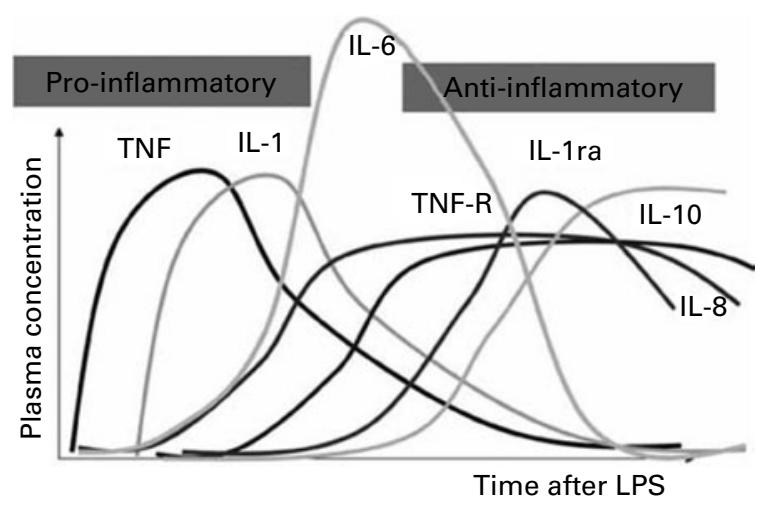

Fig. 4. The time course of plasma cytokine concentrations after an inflammatory challenge (in this case a bolus intravenous injection of Escherichia coli lipopolysaccharide (LPS)). Concentrations and time are shown on arbitrary scales. There is an initial appearance of inflammatory cytokines (TNF and IL-1), followed by IL-6, and then anti-inflammatory cytokines (TNF receptor (TNFR), IL-1 receptor antagonist (IL-1ra) and IL-10). Reproduced from Bentham Science Publishers ${ }^{(300)}$ with permission.

antibody titres can be used as a readout at a later stage so that a single study can be used to measure two different immunological outcomes (inflammation and immune response). However, it should be noted that pre-existing elevated baseline levels of pro-inflammatory cytokines are associated with decreased vaccination responses ${ }^{(208)}$.

Skin tests. Delayed-type hypersensitivity and contact hypersensitivity responses to locally applied antigens or contact allergens can be used to assess local inflammatory responses triggered by the specific response to the antigen or allergen. These responses rarely result in measurable effects on circulating cytokines or acute-phase proteins, but instead can be measured as local erythema or epidermal induration $24-48 \mathrm{~h}$ after application. As the skin is easily accessible, local inflammation can be studied in great detail using biopsies. Delayed-type hypersensitivity and contact hypersensitivity responses can only be elicited in sensitised subjects and rely on the uncontrolled history of exposure resulting in large variation among individuals and in many nonresponders. This is key to their diagnostic value, but hampers application as a challenge model in nutrition studies. Nonetheless, in the past, studies have successfully assessed the impact of nutrition on delayed-type hypersensitivity responses using the cell-mediated immunity multitest to simultaneously administer multiple antigens ${ }^{(209-211)}$. Unfortunately, this device is no longer available and no robust alternative methods have been described for routine application of multiple antigens. Using a single Candida antigen, delayed-type hypersensitivity responses have recently been shown to be associated with a systemic inflammatory state in older subjects (aged 60-85 years), with positive responders having significantly lower serum CRP levels ${ }^{(212)}$. To control both the sensitisation and elicitation phase, studies have also explored the use of experimental sensitisation to an uncommon contact sensitiser, diphenylcyclopropenone, that would not normally be encountered $^{(213,214)}$. Although there are ethical considerations, this has been successfully used to assess the effect of (exer- cise) intervention on both the sensitisation and elicitation phase using induration due to the local inflammation of the skin as the readout ${ }^{(215)}$.

\section{Tissue damage}

Exercise challenges. It is well established that strenuous exercise (either an acute intensive bout or longer duration such as marathon running) increases the concentrations of leucocytes and neutrophils immediately following the exercise and induces an increase in inflammatory marker concentrations in the bloodstream ${ }^{(216)}$. However, if a challenge model should be applicable to the general population to assess the impact of (dietary) interventions on the elicited inflammatory response, then a moderate exercise challenge may be more relevant. The effects of moderate aerobic exercise on pro-inflammatory cytokine production are less well characterised than the effects of strenuous exercise as discussed earlier. Most data from exercise studies relate to long-term aerobic training (in which there is an anti-inflammatory effect) and to strenuous exercise such as marathon running (in which pro-inflammatory cytokines, especially IL-6, are elevated), as discussed elsewhere ${ }^{(87,88)}$. Increases in such inflammatory cytokines after short-term exercise are much less pronounced. The production of IL- 6 increased after mild exercise in studies performed in healthy as well as diseased adults ${ }^{(217-221)}$, but was unchanged in other studies ${ }^{(222,223)}$. Whereas muscles produce the pro-inflammatory IL- 6 during acute bouts of exercise; paradoxically, IL-6 also has anti-inflammatory effects by promoting the release of IL-1 receptor antagonist and IL-10 ${ }^{(87)}$. This may in part explain the notion that regular, mild, lowimpact exercise has anti-inflammatory effects. The production of TNF remained unchanged after mild exercise in healthy as well as diseased adults in three studies $^{(220,222,224)}$ and increased in another study ${ }^{(218)}$. The numbers of circulating total leucocytes, lymphocytes and monocytes increased after mild exercise ${ }^{(225)}$. Interestingly, in some studies, inflammatory cytokines increased after moderate exercise in patients, but not in control subjects. Rabinovich et al. ${ }^{(223)}$ described that serum TNF increased in patients with cystic fibrosis after moderate exercise but not in controls. Likewise, IL-6 increased after mild exercise in cystic fibrosis patients, but not in healthy controls in another study ${ }^{(22)}$. The effect of mild exercise on CRP was only tested in a single study, and was found to be increased in patients with coronary artery disease but not in control subjects ${ }^{(219)}$. Similar findings have been seen in studies with children ${ }^{(226)}$.

UV irradiation. Whole-body exposure to high doses of sunlight or UVB radiation causing sunburn increases the levels of inflammatory mediators in the circulation. Milder or more focused exposure to UVB radiation was shown to decrease the skin contact hypersensitivity response ${ }^{(214)}$ as well as some systemic responses such as natural killer cell activity $^{(214,227)}$ and ex vivo production of cytokines ${ }^{(228)}$. However, circulating cytokine levels after single exposure to UVB were not affected $^{(229,230)}$ and even after $10 \mathrm{~d}$ of repeated exposure, only IL- 8 and TNF were marginally increased ${ }^{(230)}$. It is therefore unlikely that a practically feasible UV challenge 
can be developed that can be used to assess indicators of inflammation systemically. However, using microdialysis and/or punch biopsies, pro- and anti-inflammatory responses can be sequentially assessed in the skin in the hours to days following a single dose of two or three minimal erythemal doses of UVB radiation ${ }^{(231-233)}$. This is a useful model to assess local mediators including short-lived eicosanoids involved in the initiation and resolution phase of UVB-induced skin inflammation ${ }^{(23)}$.

\section{General comments on challenge models}

CRP, TNF and IL- 6 are the most commonly measured inflammatory markers after the various challenges, although other cytokines, chemokines, adhesion molecules and leucocyte numbers have also been used. For challenges that induce inflammation in the skin, local markers such as swelling, erythema, cellular infiltrate and local levels of mediators in exudate from (suction) blisters or biopsies have also been used. Steady-state differences in inflammatory markers between patients with diseases with an inflammatory component and healthy people seem to be more consistent than differences in post-challenge responses. However, stronger or more extended inflammatory responses (IL-6, TNF and CRP) to challenges in patients $v$. controls have also been noted in several studies. Challenges other than with glucose are not, or are poorly, standardised and differ greatly between studies with respect to the challenge (amount and quality of fats, type and duration of exercise, wavelength and energy intensity of UV radiation, and type of vaccine), markers measured, time points measured and the way in which results are analysed. In most studies, the inflammatory response is assessed at one or more arbitrary time points after the triggering challenge, few studies have followed the detailed kinetics of the responses, few included a proper time control for circadian rhythms and very few have integrated the entire response, for instance, by analysing the AUC ${ }^{(197)}$. Different challenges have been used in different contexts, using different sets of readouts and different (subject or patient) populations. This makes it complex to compare the challenges based on available data. A recent study observed that multiple intermediates of the glutathione synthesis pathway showed time-dependent suppression in response to the OGTT in overweight subjects ${ }^{(235)}$. These metabolic perturbations were subtle and were only observed using metabolic profiling at multiple time points following a physiological challenge (OGTT). This is a good example of more sophisticated integrative analysis, which may also be very useful for the detailed analysis of the kinetics of complex inflammatory responses ${ }^{(235)}$.

It would be very useful to have reliable kinetic data of the inflammatory responses following well-selected, standardised pro-inflammatory challenges. These could then serve as a starting point for systematic comparisons of the kinetic profiles in different subpopulations (obese, insulin insensitive, diabetic, older individuals, etc.) and for careful evaluations of the impact of (dietary) interventions on the resilience of these responses. The established kinetic responses following an intravenous LPS challenge could serve as a useful point of reference for this (see Fig. 4). However, care should be taken not to introduce artifacts due to the sampling as several studies have demonstrated that the mere presence of an indwelling catheter results in the continued local elevation of IL-6 levels compared with samples taken from the contralateral arm using repeated venepuncture ${ }^{(236-238)}$.

Although it may not yet be possible with the relatively limited dataset available, it would be very useful to work towards standardised challenges combined with standardised sampling and analytical regimens and standardised data analyses, and use these as an integrated biomarker of inflammatory resilience. This resembles what has been done with the OGTT for the assessment of insulin resistance and diabetes and would facilitate comparison between studies in prospective cohorts, which is needed to establish the predictive value and clinical relevance of resilience to (acute) inflammatory challenges.

Conceptually, the use of standardised challenges is an interesting approach and there are some indications that resilience of dynamic inflammatory responses may have added value over assessing markers during steady state only. However, there are too few data to draw firm conclusions at this point. Some studies have indicated different post-challenge inflammatory responses in patient populations, but it is not yet feasible to define healthy inflammatory responsiveness to a particular challenge based on the available published data. Oral glucose and fat challenges and potentially the early response to a vaccine seem to be best standardised, most relevant and most feasible challenges for application in nutrition studies and for inclusion in prospective cohort studies.

\section{Key messages}

(1) Inflammatory responsiveness or resilience to challenges may provide a more sensitive and meaningful indication of inflammatory state in the general population than the assessment of markers during steady state.

(2) There is a need to standardise challenge(s) and assessment of the subsequent inflammatory response, including multiple sampling points to assess the kinetics of the response. As many inflammatory markers also have a circadian rhythm, such studies should involve proper time controls.

(3) There is a need to firmly establish whether standardised assessment of the dynamic response to an (acute) inflammatory challenge does indeed add value (clinical relevance, sensitivity, relevance, interpretability, etc.) compared with assessment of inflammatory markers during the steady state.

(4) It is likely that a combination of multiple inflammatory markers (perhaps the same as those used to assess inflammation in the steady state) and integrated readouts based upon kinetic analysis following defined inflammatory challenges will be most informative.

\section{Emerging markers of inflammation}

\section{Expression of cell surface markers}

New technologies allow the profiling of hundreds of cell surface markers in peripheral blood and tissues, and the 
identification of surface markers whose extent of expression correlates with the inflammatory status. Recent studies have suggested that surface expression of $\mathrm{CD} 11 \mathrm{~b}$ on granulocytes is a marker of granulocyte activation; its expression is increased in obesity ${ }^{(239)}$. Weight loss in obese subjects and in individuals with diabetes is associated with decreased expression of CD11b on granulocytes and of CD66b on monocytes $^{(239)}$. CD11c, a $\beta_{2}$ integrin expressed on monocytes, plays an important role in monocyte adhesion to inflamed endothelial cells. Obese human subjects with the metabolic syndrome have higher CD11c levels on monocytes than lean healthy controls ${ }^{(240)}$, suggesting that these monocytes are involved in the inflammatory process of atherosclerosis. For these biomarkers, little information is available on the impact of confounders, such as smoking or physical (in)activity.

\section{Clusters of markers}

An important approach to ascertaining the clinical relevance of selected biomarkers of inflammation is to perform longitudinal studies following human subjects over time ${ }^{(241)}$. Several such longitudinal studies in human subjects have sought to identify biomarkers of morbidity and mortality, with mortality as the most 'robust clinical endpoint'. Inflammatory factors such as CRP, TNF and IL-6 have repeatedly been found to associate with increased mortality and frailty, but mostly in cross-sectional studies ${ }^{(242,243)}$. Moreover, analyses of associations with single factors in either cross-sectional or longitudinal studies are usually weak or not always reproduced in different populations. A major challenge in studies of longlived species like humans is clearly logistics of long-term follow-up. An approach to this was made in the Swedish immune longitudinal studies including octo- and nonagenarians (OCTO/NONA) studies, taken here as an example, which examined soluble and cellular markers at baseline in 85-year-old subjects to seek predictive biomarkers for mortality in cohorts with high mortality over reasonable followup times ${ }^{(244,245)}$. The rationale was to identify those predictive biomarkers with potential applicability to other, younger, populations. These studies not only performed follow-up at 2,4 and 6 years, but also resampled, so that changes to biomarkers over time could be assessed. It was found that single markers were relatively uninformative, as expected from the above considerations, but that clusters of markers were significantly associated with mortality. Thus, a cluster of cellular markers including an inverted CD4:CD8 ratio due to an accumulation of $\mathrm{CD}^{+}$late-stage memory cells and infection with the common herpes virus cytomegalovirus, now thought to drive this 'memory inflation', were significantly associated with mortality. Cytomegalovirus infection has a pro-inflammatory action, increasing the levels of cytokines such as interferon- $\gamma$. The OCTO/NONA studies also identified a second cluster of soluble factors comprising increased IL-6, CRP and the thyroid hormone and vitamin A transport protein transthyretin, which correlated with cognitive impairment and independently associated with mortality. Individuals with neither risk cluster had better survival at follow-up than those with either one or the other risk cluster, and people simultaneously with both risk clusters had the worst survival ${ }^{(244)}$ These findings emphasise that multiple inflammatory factors need to be assessed in combination. The importance of the balance between pro- and anti-inflammatory factors was emphasised by the finding that although the majority of subjects in this risk group were already deceased at 2- and 4-year follow-up, a minority exited the risk group and remained alive at this time. These rare individuals were characterised by high plasma IL-10 levels, as well as retaining high IL-6 levels ${ }^{(245)}$. This risk cluster remains an emerging marker because, as defined thus far, it has limitations that require further study applying more sophisticated methodology to well-characterised cohorts. These limitations include, but are not limited to, the following: the cluster has only been shown to be relevant in a small study in one very old population in one country; it lacks the sophistication of modern immune analysis; it is unknown at which calendar age it becomes relevant; associations with cause of death are unknown and associations with underlying disease states are also unknown; finally, it does not take nutrition, psychological stress or pathogen environment into account. Given that nutrients and dietary patterns may influence the components of the clusters described above ${ }^{(1,6)}$, it is likely that the clusters themselves may be targets for nutritional interventions.

\section{Stress markers}

The adverse tissue environment of immune-mediated and metabolic disease triggers a cellular stress programme in response to hypoxia, inflammation, reactive oxygen species as well as the lack or imbalanced presence of nutrients ${ }^{(246)}$ Specific metabolic and functional processes occur in specialised cellular organelles such as the ER, peroxisomes and mitochondria ${ }^{(247)}$. The unfolded protein response (UPR) is a well-conserved mechanism of these organelles to restore cellular homeostasis in response to stress; however, unresolved or chronic activation of UPR pathways induces inflammatory mechanisms or cell death. Even though they are phenotypically different, the diseases described in Table 4 share similarities of the cell stress response at the molecular level ${ }^{(248)}$. Hypoxia and inflammatory signals as well as metabolic challenges increase cellular energy requirements and reactive oxygen species production and have a negative impact on protein folding machinery of the cell. Consistently, interference with $\mathrm{ER}^{(249-251)}$ and mitochondrial UPR-associated signalling pathways ${ }^{(252-254)}$ has been shown to have an impact on disease susceptibility and pathological outcome in various animal models. Generally accepted surrogate markers for UPR include cellular expression and secretion of compartment-specific chaperones (CPN) such as glucoserelated protein (GRP) 78 and heat shock protein (HSP) 78 $\mathrm{CPN60}$, the latter representing the main $\mathrm{CPN}$ involved in protein folding in the mitochondria, since induction of these proteins is a main purpose of UPR signalling ${ }^{(255,256)}$. Increased protein and mRNA expression levels of GRP78 in human mononuclear cells were shown to be associated with deregulated blood glucose homeostasis, increased levels of 
inflammatory cytokines and the metabolic syndrome, demonstrating clinical relevance for ER-UPR markers in human disease ${ }^{(257)}$. In addition, plasma HSP60 levels were associated with hypertension and increased risk for $\mathrm{CVD}^{(258,259)}$. To evaluate ER-derived signalling leading to altered gene expression, splicing of X-box binding protein 1 (Xbp-1) mRNA is commonly monitored. The spliced mRNA encodes an active, UPR-associated transcription factor, spliced X-box binding protein 1 (sXBP-1), and splicing of Xbp-1 mRNA represents an early event during ER-UPR ${ }^{(251,255)}$. Induction of GRP78 or CPN60 is mostly measured by Western blot analysis, immunohistochemical analysis and quantitative polymerase chain reaction (PCR), whereas $X b p-1$ mRNA splicing is detected by using specific primers for $X b p-1$ mRNA or $s X b p-1$ mRNA for quantitative PCR analysis. In conclusion, GRP78 and HSP60 represent surrogate markers for chronic conditions with inflammatory pathologies that can be measured in biopsies from the disease-relevant tissue or in specifically isolated target cells as well as circulating protein in plasma ${ }^{(248)}$. These could be tested as potential early markers for the onset of inflammation, where data are not yet available, including evaluating the potential for modulation by interventions.

\section{MicroRNA}

MicroRNA (miRNA) are short (average twenty-two nucleotides) non-coding ribonucleic acids that have been found in eukaryotic cells. They have important regulatory functions by controlling gene expression, by inhibiting protein translation and by inducing target mRNA destabilisation ${ }^{(260)}$. miRNA can be detected by PCR, specific microarrays or, more comprehensively, by next-generation sequencing approaches ${ }^{(261)}$. Endogenous circulating miRNA in human plasma are potential candidates as stable biomarkers for health status, organ dysfunction and disease $e^{(262-264)}$. As many of the common diseases have an inflammatory component that may be regulated by non-coding $\mathrm{RNA}^{(265)}$, it is expected that plasma miRNA profiling will reveal sensitive biomarkers for the onset or modulation of chronic inflammation in humans ${ }^{(262,266-268)}$. The latter could include nutritional modulation.

\section{Microbiota and associated markers}

As discussed earlier, microbiota and, particularly, gut microbiota might play an important role in human health and physiopathology. It is possible that circulating traces of translocated bacteria or bacterial components could be used as biomarkers to predict metabolic disease risk in humans. Measurements of blood LPS have frequently been reported in the literature as a feature of mucosal barrier failure. However, such measures are rather unspecific, are limited to Gram-negative organisms and pose some technical difficulties. Alternative methods to detect material of bacterial origin or to detect responses to specific organisms are emerging. Indeed, a battery of antibodies against different bacterial antigens is currently under investigation, although their physiological role is still unclear. However, this approach may provide new markers of inflammation. For instance, an array of immunohistological tools have been developed to study, diagnose and/or score ulcerative colitis and Crohn's disease ${ }^{(269,270)}$. So far, the combination of perinuclear anti-neutrophil cytoplasmic antibodies (P-ANCA) and anti-Saccharomyces cerevisiae antibodies (ASCA) seems to be the best serological test to distinguish ulcerative colitis $\left(\mathrm{P}_{-} \mathrm{ANCA}^{+}\right.$and $\mathrm{ASCA}^{-/ \text {low }}$ ) from Crohn's disease $\left(\mathrm{P}-\mathrm{ANCA}^{-/ \text {low }} \text { and } \mathrm{ASCA}^{+}\right)^{(269)}$. The usefulness of such tools in the generally healthy population needs further development. In addition, specific bacterial $16 \mathrm{~S}$ ribosomal DNA detection by PCR amplification in blood is a tool being used more frequently ${ }^{(271-273)}$. The combination of excellent sensitivity and specificity, ease and speed has made real-time PCR technology an appealing alternative to conventional culture-based testing methods. This approach has been used recently to show a positive association between $16 \mathrm{~S}$ ribosomal DNA in blood and diabetes onset ${ }^{(274)}$. The $16 \mathrm{~S}$ ribosomal DNA concentration was analysed in blood in a cohort of 3280 subjects without diabetes or obesity. Baseline $16 \mathrm{~S}$ ribosomal DNA level was higher in those subjects who developed diabetes by the 9-year follow-up ${ }^{(274)}$.

\section{Key messages}

(1) Altered expression of activation markers on the surface of circulating leucocytes may be biomarkers of inflammation.

(2) Longitudinal studies of the very old suggest that a profile of plasma inflammatory markers correlates with altered risk of mortality and is more predictive than any marker alone.

(3) UPR are the consequence of sustained cellular stress in the context of immune-mediated or metabolically driven chronic pathologies with GRP78 and CPN60 as surrogate markers.

(4) Endogenous circulating miRNA are quite stable potential biomarkers for health status and organ dysfunctions, and may reveal very sensitive information about inflammatory state.

(5) There are emerging approaches to assess the microbiota and the translocation of micro-organisms.

(6) These emerging markers of inflammation may be influenced by nutrition and represent potential novel targets for nutritional interventions.

\section{Emerging technologies}

Applications of omic technologies to identify new markers and to monitor the effect of interventions

Genomics was originally described as the comprehensive analysis of the genome of an organism that includes efforts to determine the entire DNA sequence and fine-scale genetic mapping. A broader definition than this may also be used $^{(275)}$, according to which 'genomics' is the study of all of the genes of a cell, or tissue, at the DNA (epigenome, genome), mRNA (transcriptome) and protein (proteome) levels. New high-throughput technologies such transcriptomics, 
proteomics and metabolomics have created unprecedented opportunities for a less biased and more comprehensive assessment of even subtle phenotypic changes. To integrate applications of these technologies more efficiently into nutrition research, nutrigenomics has been initiated as a new innovative research strategy about 10 years ago when the working draft of the human genome was announced ${ }^{(276-280)}$. In addition to comprehensive phenotyping, nutrigenomics includes innovative combinations of molecular nutrition research and genomics applications. It allows the comprehensive study of diverse tissue and organ-specific gene expression patterns (transcriptome), organisation and modification of the chromatin structure (epigenome), protein expression patterns including post-translational modifications (proteome) as well as metabolite profiles (metabolome) ${ }^{(279,281)}$. To achieve the powerful integration of all different nutrigenomic and phenotype data systems, biology strategies are being developed. Nutritional systems biology is a holistic approach merging various omics data (e.g. genome, epigenome, metabolome, proteome, microbiome) from individual organs and body compartments at different time points of a nutritional intervention with the use of computational methods and predictive mathematical models. This requires a large degree of standardisation, multidisciplinary collaboration, improved bioinformatics and statistical methods and sophisticated and partly Web-based databases such as the Nutritional Phenotype database ${ }^{(282,283)}$.

It is becoming evident from recent studies that nutrigenomics is promoting an increased understanding of how a nutritional intervention mechanistically influences metabolic pathways and homeostatic control. Furthermore, it reveals how this regulation is disturbed during development of diseases, and the extent to which individual sensitising genotypes contribute to such diseases by allowing comprehensive phenotyping and the identification of early biomarkers for pre-disease states. A few recent nutrigenomics-based applications related to systemic and organ-related pro-inflammatory states are discussed here. Nutrigenomics studies using appropriate mouse models are essential to better understand the systems-wide changes of a metabolically healthy to a less healthy organism and to identify potential early biomarkers that can then be validated in human studies ${ }^{(284-286)}$. Recent studies have already shown the great opportunities of this new research area ${ }^{(191,287,288)}$.

Whole genome transcriptome analysis has been used to demonstrate that intake of $n$ - 3 fatty acids by healthy older persons for 26 weeks can alter the gene expression profiles of peripheral blood mononuclear cells, as a 'surrogate' biomarker for whole-body health status, to a more anti-inflammatory and antiatherogenic status, although CRP was not changed ${ }^{(289)}$. Pathway analyses revealed significantly decreased expression of genes involved in inflammatory pathways, such as eicosanoid synthesis, cytokine signalling and mitogen-activated protein kinase signalling, and in pathways related to atherosclerotic processes, such as cell adhesion and scavenger receptor activity $^{(289)}$. A combination of peripheral blood mononuclear cells and adipose tissue transcriptome, plasma protein analysis and plasma and urine metabolomics was used to study the effects of specific dietary components to reduce low-grade inflammation as well as metabolic and oxidative stress in healthy overweight men with mildly elevated plasma CRP levels ${ }^{(290)}$. Whereas CRP levels were again found to be unchanged, a multitude of subtle changes were detected by an integrated analysis of nutrigenomics datasets, which indicated modulated inflammation of adipose tissue, improved endothelial function, altered oxidative stress and increased liver fatty acid oxidation. Another nutrigenomics study investigated the effect of saturated and monounsaturated fatrich diets on insulin sensitivity, serum lipids and gene expression profiles of adipose tissue in subjects at risk of the metabolic syndrome ${ }^{(291)}$. Consumption of the saturated fatrich diet resulted in the up-regulation of processes related to inflammation. Several genes linked to inflammation included markers for recruitment of leucocytes, genes involved in eicosanoid synthesis and monocyte/macrophage markers. The monounsaturated fat-rich diet led to a more anti-inflammatory gene expression profile and resulted in a down-regulation of several adipose tissue macrophage genes. This study showed that subtle organ-specific changes in phenotypic profiles could be detected with genomics methods, which is very relevant to discriminate between early organ-related changes and late systemic changes in (pro-)inflammatory and less healthy status.

In a more recent study, a large set of plasma proteins related to chronic diseases, inflammation, endothelial function and metabolic signalling was assessed in a population of relatively healthy, middle-aged, overweight subjects ${ }^{(291,292)}$. Clusters of proteins associated with BMI or insulin were identified. Leptin and a number of pro-inflammatory proteins, previously identified as possible biomarkers for obesity-related disease (e.g. C3, CRP, serum amyloid P, vascular endothelial growth factor), clustered together and were positively associated with BMI and insulin. IL-3 and IL-13 clustered together with apoA1 and were inversely associated with BMI, and might be potential new biomarkers. These plasma protein clusters could have potential applications for improved phenotypic characterisation of subjects in nutritional intervention studies or as biomarkers in the early detection of obesity-linked disease development and progression.

As the recent developments in using nutrigenomics for metabolic profiling and characterising complex interactions are looking very promising, future studies have to link these results to accepted functional outcome measures. Application of metabolic perturbations in combination with comprehensive nutrigenomics-based phenotyping will improve the diagnostic sensitivity and ultimately allow discriminating between healthy, less healthy and unhealthy people ${ }^{(181,235,293)}$

\section{Non-invasive imaging}

Recent developments in non-invasive molecular imaging (such as magnetic resonance imaging) are allowing quantification of physiological changes in vivo using specific probes. Nanoprobes can be used to image specific cells and tissues within a whole organism, at the moment mainly in animal models such as mice ${ }^{(294)}$. Intravital fluorescence microscopy in mice is beginning to provide quantitative and dynamic insights into cell biology and immunology ${ }^{(295)}$. 
Recent application of specific mass spectrometry techniques in combination with magnetic resonance imaging has provided a systems biology approach to study inflammation in mice ${ }^{(296)}$. In a recent study, novel microscopy techniques have been used to characterise the composition of visceral adipose tissues of lean and obese mice including adipocytes, macrophages and collagen fibrils in a label-free manner, allowing dynamical monitoring of lipid metabolism-related processes relevant for immunometabolism ${ }^{(297)}$. Finally, non-invasive imaging has been applied in mouse models of inflammatory disease and for imaging of macrophages in vivo by using activatable fluorescent probes, radiolabelled inhibitors and nanoparticles ${ }^{(298)}$. Increasingly, these imaging techniques are also discussed for their potential to identify subclinical atherosclerosis in humans ${ }^{(299)}$. The goals for the years to come must include translation of the experimental work to visualisation of biological targets relevant for local organ-related and systemic inflammatory states in humans.

\section{Key messages}

(1) Applications of metabolic perturbations in combination with comprehensive nutrigenomics-based phenotyping will significantly improve the diagnostic sensitivity, allowing discrimination between healthy, less healthy and unhealthy people.

(2) For predictive mathematical modelling of the modulation of inflammatory states by nutritional interventions, the integration of different nutrigenomics and phenotype data from individual organs and body compartments has to be achieved by nutritional systems biology approaches.

(3) A range of imaging techniques is emerging that have the potential to non-invasively identify inflammation and its consequences.

\section{Summary, conclusions, identification of key gaps, overall recommendations and overall key messages}

There is an urgent necessity for reliably monitoring inflammatory status in the context of disease and interventions to prevent or treat disease, including dietary modification. Currently, guidelines on how to accurately assess inflammation are lacking. To monitor inflammation in a meaningful way, the markers used must be valid; that is, they must reflect the inflammatory process under study and they must be predictive of future health status. Inflammation per se is a normal, essential, complex physiological process crucial for restoring and maintaining health. This process involves many cells and mediators. The latter include numerous peptides and proteins that circulate in the bloodstream (e.g. cytokines, chemokines, soluble forms of adhesion molecules and acute-phase proteins). These are involved in, or produced as a result of, the inflammatory process irrespective of its trigger and its location. Thus, they are common to all inflammatory diseases, to acute and chronic inflammatory responses and to both high-grade and low-grade inflammation. They would be considered as general markers of inflammation, with no specificity with regard to the trigger or the site of inflammatory activity. Furthermore, many of these soluble markers are present at readily detectable concentrations in the bloodstream of healthy individuals, although it is not always clear what their role in healthy persons might be. In contrast, there are inflammatory markers specific to inflammatory disease, which cannot usually be measured, or are present at very low concentrations, in healthy individuals. The focus in inflammation research has been very much on such pro-inflammatory markers that are part of an amplification cascade or that cause tissue damage, and the factors that influence these and which can be used to distinguish disease. There has been less emphasis on anti-inflammatory markers, which include receptor antagonists, soluble forms of receptors, cytokines and lipid mediators that act to down-regulate the production of inflammatory mediators. There is even less understanding of those factors that terminate (resolve) inflammation. Currently, there is no consensus on which markers of inflammation best represent low-grade inflammation or can differentiate between acute and chronic inflammation or among the initiation, propagation and resolution phases of inflammatory responses. For most inflammatory markers, there is limited information on the predictive value of (differences in or changes in) their concentration from prospective studies; that is, information on their role as (independent) markers of disease risk and outcome is largely lacking. Many modifying factors affect the concentration of an inflammatory marker at a given time; the effects of some factors, such as age, physical (in)activity and smoking, on a small number of inflammatory markers are well described, but the effects of these factors on the range of markers considered here are mostly not known. In particular, knowledge of the effects of genotype, sex and gut microbiota is limited. In addition, those modifying factors for which there are relatively few data (e.g. genotype) may have a larger effect on inflammatory responses than factors for which there are larger amounts of data available. Measuring the concentration of inflammatory markers in the bloodstream under basal conditions (e.g. in fasted blood in the early morning) is probably not as informative as data related to the concentration change in response to a challenge. In the literature, a number of challenges reflecting metabolic stress, infection and tissue damage have been described. However, many of these challenges are poorly standardised, and the nature of the dynamic of the response, the markers influenced (or not), the extent of variation in the response among individuals and the effect of modifiers on the response are currently not well documented. Efforts to standardise pro-inflammatory challenge tests to assess the resilience of inflammatory control are urgently needed. Most intervention studies focus on a single marker, or on a small number of markers, of inflammation. There are few attempts to define composite markers that may be more specific or predictive. Patterns and clusters may be more robust biomarkers of inflammatory state and inflammatory response than individual or small numbers of markers. Therefore, it is likely that a combination of multiple inflammatory markers (perhaps the same as those used to assess inflammation in the steady 
state) and integrated readouts based on kinetic analysis following defined challenges will be the most informative biomarker of inflammation. New techniques are emerging to monitor inflammation but these are, in general, at the early experimental stages and have had little translation to humans. There will be a need to fully validate these technologies.

\section{Overall key messages}

(1) Acute inflammation is a normal physiological response crucial for maintaining homeostatic control, but when it becomes chronic, inflammation contributes to the pathophysiology of a range of diseases.

(2) Common soluble markers of inflammation include cytokines, chemokines, lipids, acute-phase proteins and adhesion molecules and common blood cellular markers of inflammation include various subclasses of leucocytes.

(3) The same markers are involved in both acute and chronic inflammatory processes, meaning that the markers themselves, in isolation, cannot be used to distinguish the two processes.

(4) There are a number of endogenous and exogenous modifiers that influence the levels of inflammatory markers resulting in significant between-individual variation. These modifiers include age, body fatness, physical (in)activity, sex, genotype, smoking habits, diet, the composition of the gut microbiota and the use of certain medications.

(5) Inflammatory responsiveness or resilience to challenges may provide a more sensitive and meaningful indication of inflammatory state in the general population than the assessment of markers during the steady state.

(6) There is a need to standardise pro-inflammatory challenge(s) and assessment of the subsequent inflammatory response.

(7) It is likely that a combination of multiple inflammatory markers (perhaps the same as those used to assess inflammation in the steady state) and integrated readouts based on kinetic analysis following defined challenges will be the most informative biomarker of inflammation.

(8) A number of novel markers of inflammation are emerging but these require further exploration and validation.

\section{Acknowledgements}

This work was commissioned by the Nutrition and Immunity Task Force of the European branch of the International Life Sciences Institute (ILSI Europe). Industry members of this task force are Danone, Institut Mérieux, Nestlé, Pfizer Consumer Healthcare, FrieslandCampina, Seven Seas, Südzucker/ BENEO Group, Unilever and Yakult Europe. This publication was coordinated by Lena Jönnson and Marie Latulippe, Scientific Project Managers at ILSI Europe. For further information about ILSI Europe, please email info@ilsieurope.be or call +32277100 14. The opinions expressed herein and the conclusions of this publication are those of the authors and do not necessarily represent the views of ILSI Europe nor those of its member companies. A draft of this report was discussed at a workshop held in Seville, Spain from 14 to 16 May 2012. In addition to the authors, the following individuals attended the workshop and contributed to the discussions: Jalil Benyacoub, Nestlé Research Center, Switzerland; Deborah Braun, Institut Mérieux, France; Maria Denis, Biomedical Sciences Research Centre; Alexander Fleming, Greece; Kevin Fritsche, University of Missouri, USA; Ellen Kreijveld, Unilever, The Netherlands; Jose Lopez Miranda, University of Cordoba, Spain; Anna Nicolaou, University of Bradford, UK; Fátima Pérez de Heredia, Spanish National Research Council, Spain; André Siemensma, FrieslandCampina, The Netherlands; Cathy Signoret, Cosucra Groupe Warcoing, Belgium; Ben van Ommen, TNO, The Netherlands; Willem Vas Dias, Seven Seas, UK; Stéphane Vidry, ILSI Europe, Belgium; Neil Walsh, Bangor University, UK; Danielle Wolvers, Unilever, The Netherlands. The authors thank these individuals for their valuable input. P. C. C. has research funding from Beneo-Orafti, BeghinMeiji, Abbott Nutrition and ViforPharma and is a consultant to Danone. R. A. was an employee of Unilever R\&D until 2012 and has been an employee of NutriLeads since that time. N. B. is an employee of Nestlé Research Center. R. B.-S. is an employee of Danone. L. S. J. and M. E. L. are employees of ILSI Europe. J. M. is an employee of Pfizer. C. M. is an employee of Institut Mérieux. M. M. and A. M. are government employees and have no conflicts of interest to declare. G. P. was a consultant to Unilever Central Research. R. J. J. v. N. is an employee of FrieslandCampina. J. Z. is an employee of Yakult Europe. The remaining authors have no conflicts of interest. All authors contributed to discussions and had input into writing the article. All authors read and approved the final version of the article.

\section{References}

1. Calder PC, Albers R, Antoine JM, et al. (2009) Inflammatory disease processes and interactions with nutrition. BrJ Nutr 101, Suppl. 1, S1-S45.

2. Sun S, Ji Y, Kersten S, et al. (2012) Mechanisms of inflammatory responses in obese adipose tissue. Annu Rev Nutr 32, 261-286.

3. Iyer SS \& Cheng G (2012) Role of interleukin 10 transcriptional regulation in inflammation and autoimmune disease. Crit Rev Immunol 32, 23-63.

4. Fredman G \& Serhan CN (2011) Specialized proresolving mediator targets for RvE1 and RvD1 in peripheral blood and mechanisms of resolution. Biochem J 437, 185-197.

5. Serhan CN \& Savill J (2005) Resolution of inflammation: the beginning programs the end. Nat Immunol 6, 1191-1197.

6. Calder PC, Ahluwalia N, Brouns F, et al. (2011) Dietary factors and low-grade inflammation in relation to overweight and obesity. Br J Nutr 106, S1-S78.

7. Conde J, Scotece M, Gomez R, et al. (2011) Adipokines: biofactors from white adipose tissue. A complex hub among inflammation, metabolism, and immunity. Biofactors $\mathbf{3 7}$, 413-420.

8. Kalupahana NS, Moustaid-Moussa N \& Claycombe KJ (2012) Immunity as a link between obesity and insulin resistance. Mol Aspects Med 33, 26-34.

9. Glass CK \& Witztum JL (2001) Atherosclerosis. The road ahead. Cell 104, 503-516. 
10. Hansson GK (2005) Inflammation, atherosclerosis, and coronary artery disease. N Engl J Med 352, 1685-1695.

11. Ross R (1999) Atherosclerosis - an inflammatory disease $N$ Engl J Med 340, 115-126.

12. Biomarkers Definition Working Group (2001) Biomarkers and surrogate endpoints: preferred definitions and conceptual framework. Clin Pharmacol Ther 69, 89-95.

13. Institute of Medicine of the National Academies of Science (2010) Evaluation of Biomarkers and Surrogate Endpoints in Chronic Disease. Washington, DC: The National Academy Press.

14. Ferrucci L, Corsi A, Lauretani F, et al. (2005) The origins of age-related proinflammatory state. Blood 105, 2294-2299.

15. Krabbe KS, Pedersen M \& Bruunsgaard H (2004) Inflammatory mediators in the elderly. Exp Gerontol 39, 687-699.

16. Otsuka R, Tamakoshi K, Wada K, et al. (2008) Having more healthy practice was associated with low white blood cell counts in middle-aged Japanese male and female workers. Ind Health 46, 341-347.

17. Rana JS, Boekholdt SM, Ridker PM, et al. (2007) Differential leucocyte count and the risk of future coronary artery disease in healthy men and women: the EPIC-Norfolk Prospective Population Study. J Intern Med 262, 678-689.

18. Fagiolo U, Cossarizza A, Scala E, et al. (1993) Increased cytokine production in mononuclear cells of healthy elderly people. Eur J Immunol 23, 2375-2378.

19. Pietschmann P, Gollob E, Brosch S, et al. (2003) The effect of age and gender on cytokine production by human peripheral blood mononuclear cells and markers of bone metabolism. Exp Gerontol 38, 1119-1127.

20. Hager K, Machein U, Krieger S, et al. (1994) Interleukin-6 and selected plasma proteins in healthy persons of different ages. Neurobiol Aging 15, 771-772.

21. Roubenoff R, Harris TB, Abad LW, et al. (1998) Monocyte cytokine production in an elderly population: effect of age and inflammation. J Gerontol A Biol Sci Med Sci $\mathbf{5 3}$ M20-M26.

22. Paolisso G, Rizzo MR, Mazziotti G, et al. (1998) Advancing age and insulin resistance: role of plasma tumor necrosis factor-alpha. Am J Physiol 275, E294-E299.

23. Bruunsgaard H, Andersen-Ranberg K, Jeune B, et al. (1999) A high plasma concentration of TNF-alpha is associated with dementia in centenarians. J Gerontol A Biol Sci Med Sci 54, M357-M364.

24. Shurin GV, Yurkovetsky ZR, Chatta GS, et al. (2007) Dynamic alteration of soluble serum biomarkers in healthy aging. Cytokine 39, 123-129.

25. Catania A, Airaghi L, Motta P, et al. (1997) Cytokine antagonists in aged subjects and their relation with cellular immunity. J Gerontol A Biol Sci Med Sci 52, B93-B97.

26. Yasuma TR, Nakamura M, Nishiguchi KM, et al. (2010) Elevated C-reactive protein levels and ARMS2/HTRA1 gene variants in subjects without age-related macular degeneration. Mol Vis 16, 2923-2930.

27. Akbay E, Yetkin I, Ersoy R, et al. (2004) The relationship between levels of alpha1-acid glycoprotein and metabolic parameters of diabetes mellitus. Diabetes Nutr Metab 17, $331-335$.

28. Aliberti G, Proietta M, Pulignano I, et al. (2010) Association between fibrinogen plasma levels and platelet counts in an outpatient population and in patients with coronary heart disease. Blood Coagul Fibrinolysis 21, 216-220.

29. Forsey RJ, Thompson JM, Ernerudh J, et al. (2003) Plasma cytokine profiles in elderly humans. Mech Ageing Dev 124, 487-493.
30. Richter V, Rassoul F, Purschwitz K, et al. (2003) Circulating vascular cell adhesion molecules VCAM-1, ICAM-1, and E-selectin in dependence on aging. Gerontology 49, 293-300

31. Seidler S, Zimmermann HW, Bartneck M, et al. (2010) Agedependent alterations of monocyte subsets and monocyterelated chemokine pathways in healthy adults. $B M C$ Immunol 11, 30.

32. von Eyben FE, Mouritsen E, Holm J, et al. (2005) Plasminogen activator inhibitor 1 activity and other coronary risk factors. Clin Appl Thromb Hemost 11, 55-61.

33. Koh SJ, Hyun YJ, Choi SY, et al. (2008) Influence of age and visceral fat area on plasma adiponectin concentrations in women with normal glucose tolerance. Clin Chim Acta 389, 45-50

34. Ku BJ, Kim SY, Lee TY, et al. (2009) Serum ferritin is inversely correlated with serum adiponectin level: populationbased cross-sectional study. Dis Markers 27, 303-310.

35. Remarque E \& Pawelec G (1998) T-cell immunosenescence and its clinical relevance in man. Rev Clin Gerontol 8, 5-14.

36. Strindhall J, Nilsson BO, Lofgren S, et al. (2007) No Immune Risk Profile among individuals who reach 100 years of age: findings from the Swedish NONA immune longitudinal study. Exp Gerontol 42, 753-761.

37. Muller L, Pawelec G \& Derhovanessian E (2012) The immune system during ageing. In Diet, Immunity and Inflammation [PC Calder and $\mathrm{P}$ Yaqoob, editors]. Cambridge: Woodhead Publishing.

38. Franceschi C (2007) Inflammaging as a major characteristic of old people: can it be prevented or cured? Nutr Rev $\mathbf{6 5}$, S173-S176.

39. Ahluwalia N (2004) Aging, nutrition and immune function. J Nutr Health Aging 8, 2-6.

40. Lesourd B (2006) Nutritional factors and immunological ageing. Proc Nutr Soc 65, 319-325.

41. Larbi A, Franceschi C, Mazzatti D, et al. (2008) Aging of the immune system as a prognostic factor for human longevity. Physiology (Bethesda) 23, 64-74.

42. Ballou SP, Lozanski FB, Hodder S, et al. (1996) Quantitative and qualitative alterations of acute-phase proteins in healthy elderly persons. Age Ageing 25, 224-230.

43. Jenny NS, Tracy RP, Ogg MS, et al. (2002) In the elderly, interleukin-6 plasma levels and the $-174 \mathrm{G}>\mathrm{C}$ polymorphism are associated with the development of cardiovascular disease. Arterioscler Thromb Vasc Biol 22, 2066-2071.

44. Candore G, Colonna-Romano G, Balistreri CR, et al. (2006) Biology of longevity: role of the innate immune system. Rejuvenation Res 9, 143-148.

45. Bruunsgaard H (2002) Effects of tumor necrosis factoralpha and interleukin-6 in elderly populations. Eur Cytokine Netw 13, 389-391.

46. Nakhai Pour HR, Grobbee DE, Muller M, et al. (2007) Association of endogenous sex hormone with C-reactive protein levels in middle-aged and elderly men. Clin Endocrinol (Oxf) 66, 394-398.

47. Guigoz Y, Dore J \& Schiffrin EJ (2008) The inflammatory status of old age can be nurtured from the intestinal environment. Curr Opin Clin Nutr Metab Care 11, 13-20.

48. Biagi E, Nylund L, Candela M, et al. (2010) Through ageing, and beyond: gut microbiota and inflammatory status in seniors and centenarians. PLoS One 5, e10667.

49. Lio D, Scola L, Crivello A, et al. (2003) Inflammation, genetics, and longevity: further studies on the protective effects in men of IL-10 - 1082 promoter SNP and its interaction 
with TNF-alpha -308 promoter SNP. J Med Genet 40, 296-299.

50. Iannitti T \& Palmieri B (2011) Inflammation and genetics: an insight in the centenarian model. Hum Biol 83, 531-559.

51. Weisberg SP, McCann D, Desai M, et al. (2003) Obesity is associated with macrophage accumulation in adipose tissue. J Clin Invest 112, 1796-1808.

52. Lee YJ, Shin YH, Kim JK, et al. (2010) Metabolic syndrome and its association with white blood cell count in children and adolescents in Korea: the 2005 Korean National Health and Nutrition Examination Survey. Nutr Metab Cardiovasc Dis 20, 165-172.

53. Margolis KL, Manson JE, Greenland P, et al. (2005) Leukocyte count as a predictor of cardiovascular events and mortality in postmenopausal women: the Women's Health Initiative Observational Study. Arch Intern Med 165, 500-508.

54. Skinner AC, Steiner MJ, Henderson FW, et al. (2010) Multiple markers of inflammation and weight status: crosssectional analyses throughout childhood. Pediatrics 125, e801-e809.

55. Corica F, Allegra A, Corsonello A, et al. (1999) Relationship between plasma leptin levels and the tumor necrosis factoralpha system in obese subjects. Int J Obes Relat Metab Disord 23, 355-360.

56. Winkler G, Lakatos P, Salamon F, et al. (1999) Elevated serum TNF-alpha level as a link between endothelial dysfunction and insulin resistance in normotensive obese patients. Diabet Med 16, 207-211.

57. Ziccardi P, Nappo F, Giugliano G, et al. (2002) Reduction of inflammatory cytokine concentrations and improvement of endothelial functions in obese women after weight loss over one year. Circulation 105, 804-809.

58. Meier CA, Bobbioni E, Gabay C, et al. (2002) IL-1 receptor antagonist serum levels are increased in human obesity: a possible link to the resistance to leptin? J Clin Endocrinol Metab 87, 1184-1188.

59. Hofso D, Ueland T, Hager $\mathrm{H}$, et al. (2009) Inflammatory mediators in morbidly obese subjects: associations with glucose abnormalities and changes after oral glucose. Eur $J$ Endocrinol 161, 451-458.

60. Ueland T, Kristo C, Godang K, et al. (2003) Interleukin-1 receptor antagonist is associated with fat distribution in endogenous Cushing's syndrome: a longitudinal study. J Clin Endocrinol Metab 88, 1492-1496.

61. Bastard JP, Jardel C, Bruckert E, et al. (2000) Elevated levels of interleukin 6 are reduced in serum and subcutaneous adipose tissue of obese women after weight loss. J Clin Endocrinol Metab 85, 3338-3342.

62. Yudkin JS, Stehouwer CD, Emeis JJ, et al. (1999) C-reactive protein in healthy subjects: associations with obesity, insulin resistance, and endothelial dysfunction: a potential role for cytokines originating from adipose tissue? Arterioscler Thromb Vasc Biol 19, 972-978.

63. Kim CS, Park HS, Kawada T, et al. (2006) Circulating levels of MCP-1 and IL- 8 are elevated in human obese subjects and associated with obesity-related parameters. Int $J$ Obes (Lond) 30, 1347-1355.

64. Straczkowski M, Dzienis-Straczkowska S, Stepien A, et al. (2002) Plasma interleukin-8 concentrations are increased in obese subjects and related to fat mass and tumor necrosis factor-alpha system. J Clin Endocrinol Metab 87, 4602-4606.

65. Christiansen T, Richelsen B \& Bruun JM (2005) Monocyte chemoattractant protein-1 is produced in isolated adipo- cytes, associated with adiposity and reduced after weight loss in morbid obese subjects. Int J Obes (Lond) 29 , $146-150$.

66. Schernthaner GH, Kopp HP, Kriwanek S, et al. (2006) Effect of massive weight loss induced by bariatric surgery on serum levels of interleukin-18 and monocyte-chemoattractant-protein-1 in morbid obesity. Obes Surg 16, 709-715.

67. Tchernof A, Nolan A, Sites CK, et al. (2002) Weight loss reduces C-reactive protein levels in obese postmenopausal women. Circulation 105, 564-569.

68. Visser M, Bouter LM, McQuillan GM, et al. (1999) Elevated C-reactive protein levels in overweight and obese adults. JAMA 282, 2131-2135.

69. Zhao Y, He X, Shi X, et al. (2010) Association between serum amyloid A and obesity: a meta-analysis and systematic review. Inflamm Res 59, 323-334.

70. Hanusch-Enserer U, Zorn G, Wojta J, et al. (2009) Non-conventional markers of atherosclerosis before and after gastric banding surgery. Eur Heart J 30, 1516-1524.

71. Roberts CK, Won D, Pruthi S, et al. (2006) Effect of a shortterm diet and exercise intervention on oxidative stress, inflammation, MMP-9, and monocyte chemotactic activity in men with metabolic syndrome factors. J Appl Physiol 100, 1657-1665

72. Russell M, Mendes N, Miller KK, et al. (2010) Visceral fat is a negative predictor of bone density measures in obese adolescent girls. J Clin Endocrinol Metab 95, 1247-1255.

73. Thompson AM, Zhang Y, Tong W, et al. (2011) Association of obesity and biomarkers of inflammation and endothelial dysfunction in adults in Inner Mongolia, China. Int J Cardiol 150, 247-252.

74. Zanni MV, Stanley TL, Makimura H, et al. (2010) Effects of TNF-alpha antagonism on E-selectin in obese subjects with metabolic dysregulation. Clin Endocrinol (Oxf) 73, 48-54.

75. Maachi M, Pieroni L, Bruckert E, et al. (2004) Systemic lowgrade inflammation is related to both circulating and adipose tissue TNFalpha, leptin and IL-6 levels in obese women. Int J Obes Relat Metab Disord 28, 993-997.

76. Arita Y, Kihara S, Ouchi N, et al. (1999) Paradoxical decrease of an adipose-specific protein, adiponectin, in obesity. Biochem Biophys Res Commun 257, 79-83.

77. Inadera $H$ (2008) The usefulness of circulating adipokine levels for the assessment of obesity-related health problems. Int J Med Sci 5, 248-262.

78. Yang WS, Lee WJ, Funahashi T, et al. (2001) Weight reduction increases plasma levels of an adipose-derived anti-inflammatory protein, adiponectin. J Clin Endocrinol Metab 86, 3815-3819.

79. Weiss R (2007) Fat distribution and storage: how much, where, and how? Eur J Endocrinol 157, Suppl. 1, S39-S45.

80. Greenfield JR \& Campbell LV (2006) Relationship between inflammation, insulin resistance and type 2 diabetes: 'cause or effect'? Curr Diabetes Rev 2, 195-211.

81. Rabkin SW (2007) Epicardial fat: properties, function and relationship to obesity. Obes Rev $\mathbf{8}, 253-261$.

82. Silaghi A, Piercecchi-Marti MD, Grino M, et al. (2008) Epicardial adipose tissue extent: relationship with age, body fat distribution, and coronaropathy. Obesity (Silver Spring) 16, 2424-2430.

83. Ondrak KS \& Hackney AC (2010) Body composition differences in normal weight, obese-overweight and anorexic adolescents: role of adipocytokines. Med Sport Sci $\mathbf{5 5}$, $32-42$.

84. Nakajima K, Yamaoka H, Morita K, et al. (2009) Elderly people with low body weight may have subtle low-grade inflammation. Obesity (Silver Spring) 17, 803-808. 
85. Stephens NA, Skipworth RJ \& Fearon KC (2008) Cachexia, survival and the acute phase response. Curr Opin Support Palliat Care 2, 267-274.

86. Martinez-Gomez D, Eisenmann JC, Gomez-Martinez S, et al. (2011) Sleep duration and emerging cardiometabolic risk markers in adolescents. The AFINOS study. Sleep Med 12, 997-1002.

87. Walsh NP, Gleeson M, Shephard RJ, et al. (2011) Position statement. Part one: immune function and exercise. Exerc Immunol Rev 17, 6-63.

88. Walsh NP, Gleeson M, Pyne DB, et al. (2011) Position statement. Part two: maintaining immune health. Exerc Immunol Rev 17, 64-103.

89. Johannsen NM, Priest EL, Dixit VD, et al. (2010) Association of white blood cell subfraction concentration with fitness and fatness. Br J Sports Med 44, 588-593.

90. Hamer M (2007) The relative influences of fitness and fatness on inflammatory factors. Prev Med 44, 3-11.

91. Abramson JL \& Vaccarino V (2002) Relationship between physical activity and inflammation among apparently healthy middle-aged and older US adults. Arch Intern Med 162, 1286-1292.

92. King DE, Carek P, Mainous AG, et al. (2003) Inflammatory markers and exercise: differences related to exercise type. Med Sci Sports Exerc 35, 575-581.

93. Mora S, Lee IM, Buring JE, et al. (2006) Association of physical activity and body mass index with novel and traditional cardiovascular biomarkers in women. JAMA 295, 1412-1419.

94. Panagiotakos DB, Pitsavos C, Chrysohoou C, et al. (2005) The associations between leisure-time physical activity and inflammatory and coagulation markers related to cardiovascular disease: the ATTICA Study. Prev Med $\mathbf{4 0}$, 432-437.

95. Pischon T, Hankinson SE, Hotamisligil GS, et al. (2003) Leisure-time physical activity and reduced plasma levels of obesity-related inflammatory markers. Obes Res 11, 1055-1064

96. Wannamethee SG, Lowe GD, Whincup PH, et al. (2002) Physical activity and hemostatic and inflammatory variables in elderly men. Circulation 105, 1785-1790.

97. Raitakari M, Mansikkaniemi K, Marniemi J, et al. (2005) Distribution and determinants of serum high-sensitive C-reactive protein in a population of young adults: The Cardiovascular Risk in Young Finns Study. $J$ Intern Med 258, 428-434.

98. Church TS, Barlow CE, Earnest CP, et al. (2002) Associations between cardiorespiratory fitness and C-reactive protein in men. Arterioscler Thromb Vasc Biol 22, 1869-1876.

99. Bautmans I, Njemini R, Vasseur S, et al. (2005) Biochemical changes in response to intensive resistance exercise training in the elderly. Gerontology 51, 253-265.

100. Fischer CP, Plomgaard P, Hansen AK, et al. (2004) Endurance training reduces the contraction-induced interleukin-6 mRNA expression in human skeletal muscle. Am J Physiol Endocrinol Metab 287, E1189-E1194.

101. Hammett CJ, Oxenham HC, Baldi JC, et al. (2004) Effect of six months' exercise training on C-reactive protein levels in healthy elderly subjects. J Am Coll Cardiol 44, 2411-2413.

102. Hammett CJ, Prapavessis H, Baldi JC, et al. (2006) Effects of exercise training on 5 inflammatory markers associated with cardiovascular risk. Am Heart J 151, 367e7-367e16.

103. Lakka TA, Lakka HM, Rankinen T, et al. (2005) Effect of exercise training on plasma levels of C-reactive protein in healthy adults: the HERITAGE Family Study. Eur Heart $J$ 26, 2018-2025.
104. Marcell TJ, McAuley KA, Traustadottir T, et al. (2005) Exercise training is not associated with improved levels of C-reactive protein or adiponectin. Metabolism 54, 533-541.

105. Nicklas BJ, Ambrosius W, Messier SP, et al. (2004) Dietinduced weight loss, exercise, and chronic inflammation in older, obese adults: a randomized controlled clinical trial. Am J Clin Nutr 79, 544-551.

106. Martinez-Gomez D, Gomez-Martinez S, Ruiz JR, et al. (2012) Objectively-measured and self-reported physical activity and fitness in relation to inflammatory markers in European adolescents: the HELENA Study. Atherosclerosis 221, 260-267.

107. Milani RV, Lavie CJ \& Mehra MR (2004) Reduction in C-reactive protein through cardiac rehabilitation and exercise training. J Am Coll Cardiol 43, 1056-1061.

108. Rankovic G, Milicic B, Savic T, et al. (2009) Effects of physical exercise on inflammatory parameters and risk for repeated acute coronary syndrome in patients with ischemic heart disease. Vojnosanit Pregl 66, 44-48.

109. Martinez-Gomez D, Eisenmann JC, Gomez-Martinez S, et al. (2012) Associations of physical activity and fitness with adipocytokines in adolescents: the AFINOS Study. Nutr Metab Cardiovasc Dis 22, 252-259.

110. Marques-Vidal P, Bochud M, Bastardot F, et al. (2011) Levels and determinants of inflammatory biomarkers in a Swiss population-based sample (CoLaus study). PLoS One 6, e21002.

111. Bouman A, Schipper M, Heineman MJ, et al. (2004) Gender difference in the non-specific and specific immune response in humans. Am J Reprod Immunol 52, 19-26.

112. Durham A, Chou PC, Kirkham P, et al. (2010) Epigenetics in asthma and other inflammatory lung diseases. Epigenomics 2, 523-537.

113. Trenkmann M, Brock M, Ospelt C, et al. (2010) Epigenetics in rheumatoid arthritis. Clin Rev Allergy Immunol 39, $10-19$.

114. Wierda RJ, Geutskens SB, Jukema JW, et al. (2010) Epigenetics in atherosclerosis and inflammation. J Cell Mol Med 14, 1225-1240.

115. Wilson AG (2008) Epigenetic regulation of gene expression in the inflammatory response and relevance to common diseases. J Periodontol 79, 1514-1519.

116. Fishman D, Faulds G, Jeffery R, et al. (1998) The effect of novel polymorphisms in the interleukin-6 (IL-6) gene on IL-6 transcription and plasma IL-6 levels, and an association with systemic-onset juvenile chronic arthritis. J Clin Invest 102, 1369-1376.

117. Jacob CO, Fronek Z, Lewis GD, et al. (1990) Heritable major histocompatibility complex class II-associated differences in production of tumor necrosis factor alpha: relevance to genetic predisposition to systemic lupus erythematosus. Proc Natl Acad Sci U S A 87, 1233-1237.

118. Messer G, Spengler U, Jung MC, et al. (1991) Polymorphic structure of the tumor necrosis factor (TNF) locus: an NcoI polymorphism in the first intron of the human TNF-beta gene correlates with a variant amino acid in position 26 and a reduced level of TNF-beta production. $J$ Exp Med 173, 209-219.

119. Santtila S, Savinainen K \& Hurme M (1998) Presence of the IL-1RA allele 2 (IL1RN*2) is associated with enhanced IL-1beta production in vitro. Scand J Immunol 47, 195-198.

120. Stuber F, Petersen M, Bokelmann F, et al. (1996) A genomic polymorphism within the tumor necrosis factor locus influences plasma tumor necrosis factor-alpha concentrations 
and outcome of patients with severe sepsis. Crit Care Med 24, 381-384.

121. Kelberman D, Fife M, Rockman MV, et al. (2004) Analysis of common IL-6 promoter SNP variants and the AnTn tract in humans and primates and effects on plasma IL-6 levels following coronary artery bypass graft surgery. Biochim Biophys Acta 1688, 160-167.

122. Wilson AG, Gordon C, di Giovine FS, et al. (1994) A genetic association between systemic lupus erythematosus and tumor necrosis factor alpha. Eur J Immunol 24, 191-195.

123. Wilson AG, di Giovine FS \& Duff GW (1995) Genetics of tumour necrosis factor-alpha in autoimmune, infectious, and neoplastic diseases. J Inflamm 45, 1-12.

124. Read RC, Camp NJ, di Giovine FS, et al. (2000) An interleukin-1 genotype is associated with fatal outcome of meningococcal disease. J Infect Dis 182, 1557-1560.

125. Howell WM, Turner SJ, Collins A, et al. (2002) Influence of TNFalpha and LTalpha single nucleotide polymorphisms on susceptibility to and prognosis in cutaneous malignant melanoma in the British population. Eur J Immunogenet 29, $17-23$.

126. Miller MA \& Cappuccio FP (2007) Ethnicity and inflammatory pathways - implications for vascular disease, vascular risk and therapeutic intervention. Curr Med Chem 14, 1409-1425.

127. Shah T, Newcombe P, Smeeth L, et al. (2010) Ancestry as a determinant of mean population C-reactive protein values: implications for cardiovascular risk prediction. Circ Cardiovasc Genet 3, 436-444.

128. Ernst E (1995) Haemorheological consequences of chronic cigarette smoking. J Cardiovasc Risk 2, 435-439.

129. Holz T, Thorand B, Doring A, et al. (2010) Markers of inflammation and weight change in middle-aged adults: results from the prospective MONICA/KORA S3/F3 study. Obesity (Silver Spring) 18, 2347-2353.

130. Bermudez EA, Rifai N, Buring JE, et al. (2002) Relation between markers of systemic vascular inflammation and smoking in women. Am J Cardiol 89, 1117-1119.

131. Helmersson J, Larsson A, Vessby B, et al. (2005) Active smoking and a history of smoking are associated with enhanced prostaglandin F(2alpha), interleukin-6 and F2-isoprostane formation in elderly men. Atherosclerosis 181, 201-207.

132. Woodward M, Rumley A, Tunstall-Pedoe H, et al. (1999) Associations of blood rheology and interleukin-6 with cardiovascular risk factors and prevalent cardiovascular disease. Br J Haematol 104, 246-257.

133. Petrescu F, Voican SC \& Silosi I (2010) Tumor necrosis factor-alpha serum levels in healthy smokers and nonsmokers. Int J Chron Obstruct Pulmon Dis 5, 217-222.

134. Wirtz PH, von KR, Kunz-Ebrecht S, et al. (2004) Enhanced glucocorticoid sensitivity of cytokine release from circulating leukocytes stimulated with lipopolysaccharide in healthy male smokers. Brain Behav Immun 18, 536-543.

135. Bazzano LA, He J, Muntner P, et al. (2003) Relationship between cigarette smoking and novel risk factors for cardiovascular disease in the United States. Ann Intern Med 138, 891-897.

136. Frohlich M, Sund M, Lowel H, et al. (2003) Independent association of various smoking characteristics with markers of systemic inflammation in men. Results from a representative sample of the general population (MONICA Augsburg Survey 1994/95). Eur Heart J 24, 1365-1372.

137. Lind P, Engstrom G, Stavenow L, et al. (2004) Risk of myocardial infarction and stroke in smokers is related to plasma levels of inflammation-sensitive proteins. Arterioscler Thromb Vasc Biol 24, 577-582.

138. Lowe GD, Yarnell JW, Rumley A, et al. (2001) C-reactive protein, fibrin D-dimer, and incident ischemic heart disease in the Speedwell study: are inflammation and fibrin turnover linked in pathogenesis? Arterioscler Thromb Vasc Biol 21, 603-610.

139. Wannamethee SG, Lowe GD, Shaper AG, et al. (2005) Associations between cigarette smoking, pipe/cigar smoking, and smoking cessation, and haemostatic and inflammatory markers for cardiovascular disease. Eur Heart $J$ 26, $1765-1773$.

140. Yarnell JW, Sweetnam PM, Rumley A, et al. (2000) Lifestyle and hemostatic risk factors for ischemic heart disease: the Caerphilly Study. Arterioscler Thromb Vasc Biol 20, 271-279.

141. Bergmann S, Siekmeier R, Mix C, et al. (1998) Even moderate cigarette smoking influences the pattern of circulating monocytes and the concentration of sICAM-1. Respir Physiol 114, 269-275.

142. Chiu YH, Spiegelman D, Dockery DW, et al. (2011) Secondhand smoke exposure and inflammatory markers in nonsmokers in the trucking industry. Environ Health Perspect 119, 1294-1300.

143. Venn A \& Britton J (2007) Exposure to secondhand smoke and biomarkers of cardiovascular disease risk in neversmoking adults. Circulation 115, 990-995.

144. Jefferis BJ, Lowe GD, Welsh P, et al. (2010) Secondhand smoke (SHS) exposure is associated with circulating markers of inflammation and endothelial function in adult men and women. Atherosclerosis 208, 550-556.

145. Chow J, Tang H \& Mazmanian SK (2011) Pathobionts of the gastrointestinal microbiota and inflammatory disease. Curr Opin Immunol 23, 473-480.

146. Lomax AR \& Calder PC (2009) Probiotics, immune function, infection and inflammation: a review of the evidence from studies conducted in humans. Curr Pharm Des 15, $1428-1518$.

147. Chervonsky AV (2012) Intestinal commensals: influence on immune system and tolerance to pathogens. Curr Opin Immunol 24, 255-260.

148. Wu HJ \& Wu E (2012) The role of gut microbiota in immune homeostasis and autoimmunity. Gut Microbes 3, 4-14.

149. Maslowski KM \& Mackay CR (2011) Diet, gut microbiota and immune responses. Nat Immunol 12, 5-9.

150. Jiang HQ, Kushnir N, Thurnheer MC, et al. (2002) Monoassociation of SCID mice with Helicobacter muridarum, but not four other enterics, provokes IBD upon receipt of $\mathrm{T}$ cells. Gastroenterology 122, 1346-1354.

151. Seksik P (2010) [Gut microbiota and IBD]. Gastroenterol Clin Biol 34, Suppl. 1, S44-S51.

152. Peterson DA, Frank DN, Pace NR, et al. (2008) Metagenomic approaches for defining the pathogenesis of inflammatory bowel diseases. Cell Host Microbe 3, 417-427.

153. Walker AW, Ince J, Duncan SH, et al. (2011) Dominant and diet-responsive groups of bacteria within the human colonic microbiota. ISME J 5, 220-230.

154. Walker AW, Sanderson JD, Churcher C, et al. (2011) Highthroughput clone library analysis of the mucosa-associated microbiota reveals dysbiosis and differences between inflamed and non-inflamed regions of the intestine in inflammatory bowel disease. BMC Microbiol 11, 7 .

155. Sokol H, Pigneur B, Watterlot L, et al. (2008) Faecalibacterium prausnitzii is an anti-inflammatory commensal bacterium identified by gut microbiota analysis of Crohn disease patients. Proc Natl Acad Sci US A 105, 16731-16736. 
156. Sokol H, Seksik P, Furet JP, et al. (2009) Low counts of Faecalibacterium prausnitzii in colitis microbiota. Inflamm Bowel Dis 15, 1183-1189.

157. Claes IJ, De Keersmaecker SC, Vanderleyden J, et al. (2011) Lessons from probiotic-host interaction studies in murine models of experimental colitis. Mol Nutr Food Res 55, $1441-1453$.

158. Gareau MG, Sherman PM \& Walker WA (2010) Probiotics and the gut microbiota in intestinal health and disease. Nat Rev Gastroenterol Hepatol 7, 503-514.

159. Cogen AL, Nizet V \& Gallo RL (2008) Skin microbiota: a source of disease or defence? Br J Dermatol 158, 442-455.

160. Hilty M, Burke C, Pedro H, et al. (2010) Disordered microbial communities in asthmatic airways. PLoS One $\mathbf{5}$, e8578.

161. Huang YJ, Kim E, Cox MJ, et al. (2010) A persistent and diverse airway microbiota present during chronic obstructive pulmonary disease exacerbations. OMICS 14, 9-59.

162. Huang YJ, Nelson CE, Brodie EL, et al. (2011) Airway microbiota and bronchial hyperresponsiveness in patients with suboptimally controlled asthma. J Allergy Clin Immunol 127, 372-381.

163. Paulino LC, Tseng CH, Strober BE, et al. (2006) Molecular analysis of fungal microbiota in samples from healthy human skin and psoriatic lesions. J Clin Microbiol 44, 2933-2941.

164. Paulino LC, Tseng CH \& Blaser MJ (2008) Analysis of Malassezia microbiota in healthy superficial human skin and in psoriatic lesions by multiplex real-time PCR. FEMS Yeast Res 8, 460-471.

165. Delzenne NM \& Cani PD (2011) Interaction between obesity and the gut microbiota: relevance in nutrition. Annu Rev Nutr 31, 15-31.

166. Penders J, Stobberingh EE, van den Brandt PA, et al. (2007) The role of the intestinal microbiota in the development of atopic disorders. Allergy 62, 1223-1236.

167. Cani PD, Osto M, Geurts L, et al. (2012) Involvement of gut microbiota in the development of low-grade inflammation and type 2 diabetes associated with obesity. Gut Microbes 3, 279-288.

168. Clarke S, Murphy E, Nilaweera K, et al. (2012) The gut microbiota and its relationship to diet and obesity: new insights. Gut Microbes 3, 186-202.

169. Serino M, Luche E, Gres S, et al. (2011) Metabolic adaptation to a high-fat diet is associated with a change in the gut microbiota. Gut 61, 543-553.

170. Cani PD, Bibiloni R, Knauf C, et al. (2008) Changes in gut microbiota control metabolic endotoxemia-induced inflammation in high-fat diet-induced obesity and diabetes in mice. Diabetes 57, 1470-1481.

171. Furet JP, Kong LC, Tap J, et al. (2010) Differential adaptation of human gut microbiota to bariatric surgery-induced weight loss: links with metabolic and low-grade inflammation markers. Diabetes 59, 3049-3057.

172. Turnbaugh PJ, Ley RE, Mahowald MA, et al. (2006) An obesity-associated gut microbiome with increased capacity for energy harvest. Nature 444, 1027-1031.

173. Ley RE, Turnbaugh PJ, Klein S, et al. (2006) Microbial ecology: human gut microbes associated with obesity. Nature 444, 1022-1023.

174. Jumpertz R, Le DS, Turnbaugh PJ, et al. (2011) Energy-balance studies reveal associations between gut microbes, caloric load, and nutrient absorption in humans. $\mathrm{Am} \mathrm{J}$ Clin Nutr 94, 58-65.
175. Gouin JP, Hantsoo L \& Kiecolt-Glaser JK (2008) Immune dysregulation and chronic stress among older adults: a review. Neuroimmunomodulation 15, 251-259.

176. Marshall GD Jr (2011) The adverse effects of psychological stress on immunoregulatory balance: applications to human inflammatory diseases. Immunol Allergy Clin North Am 31, $133-140$.

177. Heffner KL (2011) Neuroendocrine effects of stress on immunity in the elderly: implications for inflammatory disease. Immunol Allergy Clin North Am 31, 95-108.

178. van Eeden SF, Yeung A, Quinlam K, et al. (2005) Systemic response to ambient particulate matter: relevance to chronic obstructive pulmonary disease. Proc Am Thorac Soc 2, 61-67.

179. Lorton D, Lubahn CL, Estus C, et al. (2006) Bidirectional communication between the brain and the immune system: implications for physiological sleep and disorders with disrupted sleep. Neuroimmunomodulation 13, 357-374

180. Huber M, Knottnerus JA, Green L, et al. (2011) How should we define health? BMJ 343, d4163.

181. van Ommen B, Keijer J, Heil SG, et al. (2009) Challenging homeostasis to define biomarkers for nutrition related health. Mol Nutr Food Res 53, 795-804.

182. Antuna-Puente B, Disse E, Rabasa-Lhoret R, et al. (2011) How can we measure insulin sensitivity/resistance? Diabetes Metab 37, 179-188.

183. van Leeuwen M, Louwerse M, Opmeer B, et al. (2012) Glucose challenge test for detecting gestational diabetes mellitus: a systematic review. BJOG 119, 393-401.

184. World Health Organization (2006) Definition and Diagnosis of Diabetes Mellitus and Intermediate Hyperglycemia: Report of a WHO/IDF Consultation. Geneva: WHO.

185. O'Keefe JH \& Bell DS (2007) Postprandial hyperglycemia/ hyperlipidemia (postprandial dysmetabolism) is a cardiovascular risk factor. Am J Cardiol 100, 899-904.

186. Derosa G, D'Angelo A, Salvadeo SA, et al. (2010) Oral glucose tolerance test effects on endothelial inflammation markers in healthy subjects and diabetic patients. Horm Metab Res 42, 8-13.

187. Burdge GC \& Calder PC (2005) Plasma cytokine response during the postprandial period: a potential causal process in vascular disease? BrJ Nutr 93, 3-9.

188. Ceriello A, Assaloni R, Da Ros R, et al. (2005) Effect of atorvastatin and irbesartan, alone and in combination, on postprandial endothelial dysfunction, oxidative stress, and inflammation in type 2 diabetic patients. Circulation 111, $2518-2524$.

189. Esposito K, Nappo F, Marfella R, et al. (2002) Inflammatory cytokine concentrations are acutely increased by hyperglycemia in humans: role of oxidative stress. Circulation 106, 2067-2072.

190. Kempf K, Rose B, Herder C, et al. (2006) Inflammation in metabolic syndrome and type 2 diabetes: impact of dietary glucose. Ann N Y Acad Sci 1084, 30-48.

191. Frood A (2010) Technology: a flavour of the future. Nature 468, S21-S22.

192. Esposito K, Pontillo A, Di Palo C, et al. (2003) Effect of weight loss and lifestyle changes on vascular inflammatory markers in obese women: a randomized trial. JAMA $\mathbf{2 8 9}$, 1799-1804.

193. Derosa G, Ferrari I, D'Angelo A, et al. (2009) Oral fat load effects on inflammation and endothelial stress markers in healthy subjects. Heart Vessels 24, 204-210.

194. Taudorf S, Krabbe KS, Berg RM, et al. (2007) Human models of low-grade inflammation: bolus versus continu- 
ous infusion of endotoxin. Clin Vaccine Immunol $\mathbf{1 4}$ $250-255$.

195. Starkie R, Ostrowski SR, Jauffred S, et al. (2003) Exercise and IL-6 infusion inhibit endotoxin-induced TNF-alpha production in humans. FASEB J 17, 884-886.

196. Hojman P, Taudorf S, Lundby C, et al. (2009) Erythropoietin augments the cytokine response to acute endotoxininduced inflammation in humans. Cytokine 45, 154-157.

197. Erikstrup C, Ullum H \& Pedersen BK (2006) Short-term simvastatin treatment has no effect on plasma cytokine response in a human in vivo model of low-grade inflammation. Clin Exp Immunol 144, 94-100.

198. Krogh-Madsen R, Moller K, Dela F, et al. (2004) Effect of hyperglycemia and hyperinsulinemia on the response of IL-6, TNF-alpha, and FFAs to low-dose endotoxemia in humans. Am J Physiol Endocrinol Metab 286, E766-E772.

199. Harrison NA, Brydon L, Walker C, et al. (2009) Neural origins of human sickness in interoceptive responses to inflammation. Biol Psychiatry 66, 415-422.

200. Carty CL, Heagerty P, Nakayama K, et al. (2006) Inflammatory response after influenza vaccination in men with and without carotid artery disease. Arterioscler Thromb Vasc Biol 26, 2738-2744.

201. Lanza GA, Barone L, Scalone G, et al. (2011) Inflammationrelated effects of adjuvant influenza A vaccination on platelet activation and cardiac autonomic function. J Intern Med 269, 118-125.

202. Trzonkowski P, Mysliwska J, Pawelec G, et al. (2009) From bench to bedside and back: the SENIEUR Protocol and the efficacy of influenza vaccination in the elderly. Biogerontology 10, 83-94.

203. Glaser R, Robles TF, Sheridan J, et al. (2003) Mild depressive symptoms are associated with amplified and prolonged inflammatory responses after influenza virus vaccination in older adults. Arch Gen Psychiatry 60, 1009-1014.

204. Wright CE, Strike PC, Brydon L, et al. (2005) Acute inflammation and negative mood: mediation by cytokine activation. Brain Behav Immun 19, 345-350.

205. Werba JP, Veglia F, Amato M, et al. (2008) Patients with a history of stable or unstable coronary heart disease have different acute phase responses to an inflammatory stimulus. Atherosclerosis 196, 835-840.

206. Dehqanzada ZA, Storrer CE, Hueman MT, et al. (2007) Assessing serum cytokine profiles in breast cancer patients receiving a HER2/neu vaccine using Luminex technology. Oncol Rep 17, 687-694.

207. Mysliwska J, Trzonkowski P, Szmit E, et al. (2004) Immunomodulating effect of influenza vaccination in the elderly differing in health status. Exp Gerontol 39, 1447-1458.

208. Trzonkowski P, Mysliwska J, Szmit E, et al. (2003) Association between cytomegalovirus infection, enhanced proinflammatory response and low level of anti-hemagglutinins during the anti-influenza vaccination-an impact of immunosenescence. Vaccine 21, 3826-3836.

209. Meydani SN, Barklund MP, Liu S, et al. (1990) Vitamin E supplementation enhances cell-mediated immunity in healthy elderly subjects. Am J Clin Nutr 52, 557-563.

210. Pallast EG, Schouten EG, de Waart FG, et al. (1999) Effect of 50- and 100-mg vitamin E supplements on cellular immune function in noninstitutionalized elderly persons. Am J Clin Nutr 69, 1273-1281.

211. Wolvers DA, van Herpen-Broekmans WM, Logman MH, et al. (2006) Effect of a mixture of micronutrients, but not of bovine colostrum concentrate, on immune function parameters in healthy volunteers: a randomized placebocontrolled study. Nutr J 5, 28.
212. Pence BD, Lowder TW, Keylock KT, et al. (2012) Relationship between systemic inflammation and delayed-type hypersensitivity response to Candida antigen in older adults. PLoS One 7, e36403.

213. Zachariae R, Jorgensen MM, Christensen S, et al. (1997) Effects of relaxation on the delayed-type hypersensitivity (DTH) reaction to diphenylcyclopropenone (DCP). Allergy 52, 760-764.

214. Sleijffers A, Garssen J, de Gruijl FR, et al. (2001) Influence of ultraviolet $\mathrm{B}$ exposure on immune responses following hepatitis B vaccination in human volunteers. $J$ Invest Dermatol 117, 1144-1150.

215. Harper Smith AD, Coakley SL, Ward MD, et al. (2011) Exercise-induced stress inhibits both the induction and elicitation phases of in vivo T-cell-mediated immune responses in humans. Brain Behav Immun 25, 1136-1142.

216. Pedersen BK \& Hoffman-Goetz L (2000) Exercise and the immune system: regulation, integration, and adaptation. Physiol Rev 80, 1055-1081.

217. Castellano V, Patel DI \& White LJ (2008) Cytokine responses to acute and chronic exercise in multiple sclerosis. $J$ Appl Physiol 104, 1697-1702.

218. Kinugawa T, Kato M, Ogino K, et al. (2003) Interleukin-6 and tumor necrosis factor-alpha levels increase in response to maximal exercise in patients with chronic heart failure. Int J Cardiol 87, 83-90.

219. Kop WJ, Weissman NJ, Zhu J, et al. (2008) Effects of acute mental stress and exercise on inflammatory markers in patients with coronary artery disease and healthy controls. Am J Cardiol 101, 767-773.

220. Lucia A, Smith L, Naidoo M, et al. (2008) McArdle disease: another systemic low-inflammation disorder? Neurosci Lett 431, 106-111.

221. van Helvoort HA, van de Pol MH, Heijdra YF, et al. (2005) Systemic inflammatory response to exhaustive exercise in patients with chronic obstructive pulmonary disease. Respir Med 99, 1555-1567.

222. Mercken EM, Gosker HR, Rutten EP, et al. (2009) Systemic and pulmonary oxidative stress after single-leg exercise in COPD. Chest 136, 1291-1300.

223. Rabinovich RA, Figueras M, Ardite E, et al. (2003) Increased tumour necrosis factor-alpha plasma levels during moderate-intensity exercise in COPD patients. Eur Respir J 21, 789-794.

224. Ionescu AA, Mickleborough TD, Bolton CE, et al. (2006) The systemic inflammatory response to exercise in adults with cystic fibrosis. J Cyst Fibros 5, 105-112.

225. van Helvoort HA, Heijdra YF, de Boer RC, et al. (2007) Six-minute walking-induced systemic inflammation and oxidative stress in muscle-wasted COPD patients. Chest 131, 439-445.

226. Ploeger HE, Takken T, de Greef MH, et al. (2009) The effects of acute and chronic exercise on inflammatory markers in children and adults with a chronic inflammatory disease: a systematic review. Exerc Immunol Rev 15, 6-41.

227. Gilmour JW, Vestey JP, George S, et al. (1993) Effect of phototherapy and urocanic acid isomers on natural killer cell function. J Invest Dermatol 101, 169-174.

228. Jones CD, Guckian M, el-Ghorr AA, et al. (1996) Effects of phototherapy on the production of cytokines by peripheral blood mononuclear cells and on systemic antibody responses in patients with psoriasis. Photodermatol Photoimmunol Photomed 12, 204-210.

229. McLoone P, Man I, Yule S, et al. (2004) Whole-body UVB (TL-01) or UVA-1 irradiation does not alter the levels of immunomodulatory cytokines in the serum of human 
volunteers. Photodermatol Photoimmunol Photomed 20 $76-80$.

230. Narbutt J, Lesiak A, Skibinska M, et al. (2005) Repeated doses of UVR cause minor alteration in cytokine serum levels in humans. Mediators Inflamm 2005, 298-303.

231. Angst MS, Clark JD, Carvalho B, et al. (2008) Cytokine profile in human skin in response to experimental inflammation, noxious stimulation, and administration of a COX-inhibitor: a microdialysis study. Pain 139, 15-27.

232. Averbeck M, Beilharz S, Bauer M, et al. (2006) In situ profiling and quantification of cytokines released during ultraviolet B-induced inflammation by combining dermal microdialysis and protein microarrays. Exp Dermatol 15, 447-454.

233. Brink N, Szamel M, Young AR, et al. (2000) Comparative quantification of IL-1beta, IL-10, IL-10r, TNFalpha and IL-7 mRNA levels in UV-irradiated human skin in vivo. Inflamm Res 49, 290-296.

234. Rhodes LE, Gledhill K, Masoodi M, et al. (2009) The sunburn response in human skin is characterized by sequential eicosanoid profiles that may mediate its early and late phases. FASEB J 23, 3947-3956.

235. Wopereis S, Rubingh CM, van Erk MJ, et al. (2009) Metabolic profiling of the response to an oral glucose tolerance test detects subtle metabolic changes. PLoS One 4, e4525.

236. Seiler W, Muller H \& Hiemke C (1994) Interleukin-6 in plasma collected with an indwelling cannula reflects local, not systemic, concentrations. Clin Chem 40, 1778-1779.

237. Dixon NC, Hurst TL, Talbot DC, et al. (2009) Active middleaged men have lower fasting inflammatory markers but the postprandial inflammatory response is minimal and unaffected by physical activity status. J Appl Physiol 107, 63-68.

238. Haack M, Reichenberg A, Kraus T, et al. (2000) Effects of an intravenous catheter on the local production of cytokines and soluble cytokine receptors in healthy men. Cytokine 12, 694-698

239. Viardot A, Lord RV \& Samaras K (2010) The effects of weight loss and gastric banding on the innate and adaptive immune system in type 2 diabetes and prediabetes. J Clin Endocrinol Metab 95, 2845-2850.

240. Wu H, Perrard XD, Wang Q, et al. (2010) CD11c expression in adipose tissue and blood and its role in diet-induced obesity. Arterioscler Thromb Vasc Biol 30, 186-192.

241. Derhovanessian E, Larbi A \& Pawelec G (2009) Biomarkers of human immunosenescence: impact of Cytomegalovirus infection. Curr Opin Immunol 21, 440-445.

242. Pawelec G, Derhovanessian E, Larbi A, et al. (2009) Cytomegalovirus and human immunosenescence. Rev Med Virol 19, 47-56.

243. Pawelec G, Akbar A, Caruso C, et al. (2005) Human immunosenescence: is it infectious? Immunol Rev 205, 257-268.

244. Wikby A, Ferguson F, Forsey R, et al. (2005) An immune risk phenotype, cognitive impairment, and survival in very late life: impact of allostatic load in Swedish octogenarian and nonagenarian humans. J Gerontol A Biol Sci Med Sci 60, 556-565.

245. Wikby A, Nilsson BO, Forsey R, et al. (2006) The immune risk phenotype is associated with IL- 6 in the terminal decline stage: findings from the Swedish NONA immune longitudinal study of very late life functioning. Mech Ageing Dev 127, 695-704.

246. Rath E \& Haller D (2011) Inflammation and cellular stress: a mechanistic link between immune-mediated and metabolically driven pathologies. Eur J Nutr 50, 219-233.
247. Yoshida H (2009) ER stress response, peroxisome proliferation, mitochondrial unfolded protein response and Golgi stress response. IUBMB Life 61, 871-879.

248. Renz H, von Mitius E, Brandtzaeg P, et al. (2011) Geneenvironment interactions in chronic inflammatory disease. Nat Immunol 12, 273-277.

249. Bertolotti A, Wang X, Novoa I, et al. (2001) Increased sensitivity to dextran sodium sulfate colitis in IRE1betadeficient mice. J Clin Invest 107, 585-593.

250. Ji C, Kaplowitz N, Lau MY, et al. (2011) Liver-specific loss of glucose-regulated protein 78 perturbs the unfolded protein response and exacerbates a spectrum of liver diseases in mice. Hepatology 54, 229-239.

251. Kaser A, Lee AH, Franke A, et al. (2008) XBP1 links ER stress to intestinal inflammation and confers genetic risk for human inflammatory bowel disease. Cell 134, 743-756.

252. Haga N, Saito S, Tsukumo Y, et al. (2010) Mitochondria regulate the unfolded protein response leading to cancer cell survival under glucose deprivation conditions. Cancer Sci 101, 1125-1132.

253. Lim JH, Lee HJ, Ho JM, et al. (2009) Coupling mitochondrial dysfunction to endoplasmic reticulum stress response: a molecular mechanism leading to hepatic insulin resistance. Cell Signal 21, 169-177.

254. Rath E, Berger E, Messlik A, et al. (2012) Induction of dsRNA-activated protein kinase links mitochondrial unfolded protein response to the pathogenesis of intestinal inflammation. Gut 61, 1269-1278.

255. Schroder M \& Kaufman RJ (2005) The mammalian unfolded protein response. Annu Rev Biochem 74, 739-789.

256. Zhao Q, Wang J, Levichkin IV, et al. (2002) A mitochondrial specific stress response in mammalian cells. EMBO J 21, 4411-4419.

257. Sage AT, Holtby-Ottenhof S, Shi Y, et al. (2012) Metabolic syndrome and acute hyperglycemia are associated with endoplasmic reticulum stress in human mononuclear cells. Obesity (Silver Spring) 20, 748-755.

258. Pockley AG, Wu R, Lemne C, et al. (2000) Circulating heat shock protein 60 is associated with early cardiovascular disease. Hypertension 36, 303-307.

259. Pockley AG, De Faire U, Kiessling R, et al. (2002) Circulating heat shock protein and heat shock protein antibody levels in established hypertension. $J$ Hypertens 20, 1815-1820.

260. Bartel DP (2009) MicroRNAs: target recognition and regulatory functions. Cell 136, 215-233.

261. Buermans HP, Ariyurek Y, van Ommen G, et al. (2010) New methods for next generation sequencing based microRNA expression profiling. BMC Genomics 11, 716.

262. Fichtlscherer S, Zeiher AM \& Dimmeler S (2011) Circulating microRNAs: biomarkers or mediators of cardiovascular diseases? Arterioscler Thromb Vasc Biol 31, 2383-2390.

263. Cortez MA, Bueso-Ramos C, Ferdin J, et al. (2011) MicroRNAs in body fluids-the mix of hormones and biomarkers. Nat Rev Clin Oncol 8, 467-477.

264. Vickers KC, Palmisano BT, Shoucri BM, et al. (2011) MicroRNAs are transported in plasma and delivered to recipient cells by high-density lipoproteins. Nat Cell Biol 13, 423-433.

265. O'Connell RM, Rao DS \& Baltimore D (2011) MicroRNA regulation of inflammatory responses. Annu Rev Immunol 30, 295-312.

266. Zahm AM, Thayu M, Hand NJ, et al. (2011) Circulating microRNA is a biomarker of pediatric Crohn disease. $J$ Pediatr Gastroenterol Nutr 53, 26-33. 
267. Cermelli S, Ruggieri A, Marrero JA, et al. (2011) Circulating microRNAs in patients with chronic hepatitis $\mathrm{C}$ and nonalcoholic fatty liver disease. PLoS One 6, e23937.

268. Fichtlscherer S, De Rosa S, Fox H, et al. (2010) Circulating microRNAs in patients with coronary artery disease. Circ Res 107, 677-684.

269. Bossuyt X (2006) Serologic markers in inflammatory bowel disease. Clin Chem 52, 171-181.

270. Dotan I (2010) New serologic markers for inflammatory bowel disease diagnosis. Dig Dis 28, 418-423.

271. Reesink HW, Mohammadi T, Pietersz RN, et al. (2008) Rapid screening by real-time $16 \mathrm{~S}$ rDNA PCR for bacterial contamination of blood products. Clin Chem Lab Med 46, 954-962.

272. Smith CJ \& Osborn AM (2009) Advantages and limitations of quantitative PCR (Q-PCR)-based approaches in microbial ecology. FEMS Microbiol Ecol 67, 6-20.

273. Rajendhran J \& Gunasekaran P (2011) Microbial phylogeny and diversity: small subunit ribosomal RNA sequence analysis and beyond. Microbiol Res 166, 99-110.

274. Amar J, Serino M, Lange C, et al. (2011) Involvement of tissue bacteria in the onset of diabetes in humans: evidence for a concept. Diabetologia 54, 3055-3061.

275. US Environmental Protection Agency (2011) Interim genomics policy. http://www.epa.gov/spc/genomics.htm.

276. Afman L \& Müller M (2006) Nutrigenomics: from molecular nutrition to prevention of disease. J Am Diet Assoc 106, 569-576.

277. Müller M \& Kersten S (2003) Nutrigenomics: goals and strategies. Nat Rev Genet 4, 315-322.

278. Ordovas JM \& Corella D (2004) Nutritional genomics. Annu Rev Genomics Hum Genet 5, 71-118.

279. Wittwer J, Rubio-Aliaga I, Hoeft B, et al. (2011) Nutrigenomics in human intervention studies: current status, lessons learned and future perspectives. $\mathrm{Mol}$ Nutr Food Res 55, 341-358.

280. Afman LA \& Müller M (2012) Human nutrigenomics of gene regulation by dietary fatty acids. Prog Lipid Res 51, 63-70.

281. Kussmann M \& Van Bladeren PJ (2011) The extended nutrigenomics - understanding the interplay between the genomes of food, gut microbes, and human host. Front Genet 2, 21.

282. Bouwman J, Vogels JT, Wopereis S, et al. (2012) Visualization and identification of health space, based on personalized molecular phenotype and treatment response to relevant underlying biological processes. BMC Med Genomics 5, 1.

283. van Ommen B, Bouwman J, Dragsted LO, et al. (2010) Challenges of molecular nutrition research 6 : the nutritional phenotype database to store, share and evaluate nutritional systems biology studies. Genes Nutr 5, 189-203.

284. de Wit NJ, Boekschoten MV, Bachmair EM, et al. (2011) Dose-dependent effects of dietary fat on development of obesity in relation to intestinal differential gene expression in C57BL/6J mice. PLoS One 6, e19145.

285. de Wit NJ, Bosch-Vermeulen H, de Groot PJ, et al. (2008) The role of the small intestine in the development of dietary fat-induced obesity and insulin resistance in $\mathrm{C} 57 \mathrm{BL} / 6 \mathrm{~J}$ mice. BMC Med Genomics 1, 14.

286. Duval C, Thissen U, Keshtkar S, et al. (2010) Adipose tissue dysfunction signals progression of hepatic steatosis towards nonalcoholic steatohepatitis in C57BL/6 mice. Diabetes 59, 3181-3191.

287. Grayson M (2010) Nutrigenomics. Nature 468, S1.

288. Laursen L (2010) Interdisciplinary research: big science at the table. Nature $\mathbf{4 6 8}, \mathrm{S} 2-\mathrm{S} 4$.
289. Bouwens M, van de Rest O, Dellschaft N, et al. (2009) Fishoil supplementation induces antiinflammatory gene expression profiles in human blood mononuclear cells. Am J Clin Nutr 90, 415-424.

290. Bakker GC, van Erk MJ, Pellis L, et al. (2010) An antiinflammatory dietary mix modulates inflammation and oxidative and metabolic stress in overweight men: a nutrigenomics approach. Am J Clin Nutr 91, 1044-1059.

291. van Dijk SJ, Feskens EJ, Bos MB, et al. (2009) A saturated fatty acid-rich diet induces an obesity-linked proinflammatory gene expression profile in adipose tissue of subjects at risk of metabolic syndrome. Am J Clin Nutr 90, 1656-1664.

292. van Dijk SJ, Feskens EJ, Heidema AG, et al. (2010) Plasma protein profiling reveals protein clusters related to BMI and insulin levels in middle-aged overweight subjects. PLoS One 5, e14422.

293. van Ommen B, Keijer J, Kleemann R, et al. (2008) The challenges for molecular nutrition research 2: quantification of the nutritional phenotype. Genes Nutr 3, 51-59.

294. Minchin RF \& Martin DJ (2010) Nanoparticles for molecular imaging - an overview. Endocrinology 151, 474-481.

295. Pittet MJ \& Weissleder R (2011) Intravital imaging. Cell 147 , 983-991.

296. Attia AS, Schroeder KA, Seeley EH, et al. (2012) Monitoring the inflammatory response to infection through the integration of MALDI IMS and MRI. Cell Host Microbe 11, 664-673.

297. Urasaki Y, Johlfs MG, Fiscus RR, et al. (2012) Imaging immune and metabolic cells of visceral adipose tissues with multimodal nonlinear optical microscopy. PLoS One 7, e38418.

298. Quillard T, Croce K, Jaffer FA, et al. (2011) Molecular imaging of macrophage protease activity in cardiovascular inflammation in vivo. Thromb Haemost 105, 828-836.

299. Fuster V, Lois F \& Franco M (2010) Early identification of atherosclerotic disease by noninvasive imaging. Nat Rev Cardiol 7, 327-333.

300. Andreasen AS, Krabbe KS, Krogh-Madsen R, et al. (2008) Human endotoxemia as a model of systemic inflammation. Curr Med Chem 15, 1697-1705.

301. Molteni M, Della BS, Mascagni B, et al. (1994) Secretion of cytokines upon allogeneic stimulation: effect of aging. $J$ Biol Regul Homeost Agents 8, 41-47.

302. Hise ME, Compher C, Harlan L, et al. (2006) Inflammatory mediators and immune function are altered in home parenteral nutrition patients. Nutrition 22, 97-103.

303. Gerli R, Monti D, Bistoni O, et al. (2000) Chemokines, sTNF-Rs and sCD30 serum levels in healthy aged people and centenarians. Mech Ageing Dev 121, 37-46.

304. Vendrell J, Broch M, Fernandez-Real JM, et al. (2005) Tumour necrosis factor receptors (TNFRs) in Type 2 diabetes. Analysis of soluble plasma fractions and genetic variations of TNFR2 gene in a case-control study. Diabet Med 22, 387-392.

305. Beharka AA, Meydani M, Wu D, et al. (2001) Interleukin-6 production does not increase with age. J Gerontol A Biol Sci Med Sci 56, B81-B88.

306. Cohen HJ, Pieper CF, Harris T, et al. (1997) The association of plasma IL-6 levels with functional disability in community-dwelling elderly. J Gerontol A Biol Sci Med Sci 52 , M201-M208.

307. Wei J, Xu H, Davies JL, et al. (1992) Increase of plasma IL-6 concentration with age in healthy subjects. Life Sci $\mathbf{5 1}$, $1953-1956$.

308. Rothenbacher D, Muller-Scholze S, Herder C, et al. (2006) Differential expression of chemokines, risk of stable coronary 
heart disease, and correlation with established cardiovascular risk markers. Arterioscler Thromb Vasc Biol 26, 194-199.

309. Mariani E, Cattini L, Neri S, et al. (2006) Simultaneous evaluation of circulating chemokine and cytokine profiles in elderly subjects by multiplex technology: relationship with zinc status. Biogerontology 7, 449-459.

310. Molvarec A, Szarka A, Walentin S, et al. (2011) Serum leptin levels in relation to circulating cytokines, chemokines, adhesion molecules and angiogenic factors in normal pregnancy and preeclampsia. Reprod Biol Endocrinol 9, 124.

311. Lemieux I, Pascot A, Prud'homme D, et al. (2001) Elevated C-reactive protein: another component of the atherothrombotic profile of abdominal obesity. Arterioscler Thromb Vasc Biol 21, 961-967.

312. Tsai HJ \& Tsai AC (2008) The association of plasma C-reactive protein levels with anthropometric and lipid parameters in elderly Taiwanese. Asia Pac J Clin Nutr 17, 651-656.

313. van Dielen FM, van't Veer C, Schols AM, et al. (2001) Increased leptin concentrations correlate with increased concentrations of inflammatory markers in morbidly obese individuals. Int $J$ Obes Relat Metab Disord 25 , 1759-1766.

314. Maple-Brown LJ, Cunningham J, Nandi N, et al. (2010) Fibrinogen and associated risk factors in a high-risk population: urban Indigenous Australians, the DRUID Study. Cardiovasc Diabetol 9, 69.

315. Richette P, Poitou C, Garnero P, et al. (2011) Benefits of massive weight loss on symptoms, systemic inflammation and cartilage turnover in obese patients with knee osteoarthritis. Ann Rheum Dis 70, 139-144.

316. Cugno M, Castelli R, Mari D, et al. (2012) Inflammatory and prothrombotic parameters in normotensive non-diabetic obese women: effect of weight loss obtained by gastric banding. Intern Emerg Med 7, 237-242.

317. Giordano P, Del Vecchio GC, Cecinati V, et al. (2011) Metabolic, inflammatory, endothelial and haemostatic markers in a group of Italian obese children and adolescents. Eur J Pediatr 170, 845-850.

318. Mari D, Coppola R \& Provenzano R (2008) Hemostasis factors and aging. Exp Gerontol 43, 66-73.

319. Valle JM, Estepa RM, Camacho RM, et al. (2007) Endothelial dysfunction is related to insulin resistance and inflammatory biomarker levels in obese prepubertal children. Eur J Endocrinol 156, 497-502.

320. Hollander C, Westin U, Wallmark A, et al. (2007) Plasma levels of alpha1-antichymotrypsin and secretory leukocyte proteinase inhibitor in healthy and chronic obstructive pulmonary disease (COPD) subjects with and without severe alpha1-antitrypsin deficiency. BMC Pulm Med 7, 1.

321. Phillips CM, Kesse-Guyot E, Ahluwalia N, et al. (2012) Dietary fat, abdominal obesity and smoking modulate the relationship between plasma complement component 3 concentrations and metabolic syndrome risk. Atherosclerosis 220, 513-519.

322. Engström G, Hedblad B, Janzon L, et al. (2005) Weight gain in relation to plasma levels of complement factor 3: results from a population-based cohort study. Diabetologia $\mathbf{4 8}$, 2525-2531.

323. Hermsdorff HH, Zulet MA, Abete I, et al. (2011) A legumebased hypocaloric diet reduces proinflammatory status and improves metabolic features in overweight/obese subjects. Eur J Nutr 50, 61-69.
324. Onat A, Hergenc G, Can G, et al. (2010) Serum complement C3: a determinant of cardiometabolic risk, additive to the metabolic syndrome, in middle-aged population. Metabolism 59, 628-634.

325. Sakcak I, Avsar MF, Hamamci EO, et al. (2010) Comparison of early and late changes in immunoglobulins and acute phase reactants after laparoscopic adjustable gastric banding in patients with morbid obesity. Obes Surg 20,610-615.

326. Salvi M, Pedrazzoni M, Girasole G, et al. (2000) Serum concentrations of proinflammatory cytokines in Graves' disease: effect of treatment, thyroid function, ophthalmopathy and cigarette smoking. Eur J Endocrinol 143, 197-202.

327. Nagayasu S, Suzuki S, Yamashita A, et al. (2012) Smoking and adipose tissue inflammation suppress leptin expression in Japanese obese males: potential mechanism of resistance to weight loss among Japanese obese smokers. Tob Induc Dis 10, 3.

328. Albertini JP, Valensi P, Lormeau B, et al. (1998) Elevated concentrations of soluble E-selectin and vascular cell adhesion molecule-1 in NIDDM. Effect of intensive insulin treatment. Diabetes Care 21, 1008-1013.

329. Zhong N, Wu XP, Xu ZR, et al. (2005) Relationship of serum leptin with age, body weight, body mass index, and bone mineral density in healthy mainland Chinese women. Clin Chim Acta 351, 161-168.

330. Bergmann S \& Siekmeier R (2009) Influence of smoking and body weight on adipokines in middle aged women. Eur J Med Res 14, Suppl. 4, 21-26.

331. Torres AJ, Angelo AL, Netto EM, et al. (2009) Reference range for $\mathrm{T}$ lymphocytes populations in blood donors from two different regions in Brazil. Braz J Infect Dis 13, 221-225.

332. Mathur SK, Schwantes EA, Jarjour NN, et al. (2008) Agerelated changes in eosinophil function in human subjects. Chest 133, 412-419.

333. Tanaka M, Fukui M, Tomiyasu K, et al. (2012) Eosinophil count is positively correlated with coronary artery calcification. Hypertens Res 35, 325-328.

334. Jensen EJ, Pedersen B, Narvestadt E, et al. (1998) Blood eosinophil and monocyte counts are related to smoking and lung function. Respir Med 92, 63-69.

335. Della BS, Bierti L, Presicce P, et al. (2007) Peripheral blood dendritic cells and monocytes are differently regulated in the elderly. Clin Immunol 122, 220-228.

336. MacLennon ICM, Drayson MT \& Tuddenham EGC (1999) Normal lymphocytes and non-neoplastic lymphocyte disorders. In Postgraduate Haematology [AV Hoffbrand and SM Lewis, editors]. Oxford: Butterworth Heinemann.

337. Heesen C, Gold SM, Hartmann S, et al. (2003) Endocrine and cytokine responses to standardized physical stress in multiple sclerosis. Brain Behav Immun 17, 473-481.

338. Mehta NN, McGillicuddy FC, Anderson PD, et al. (2010) Experimental endotoxemia induces adipose inflammation and insulin resistance in humans. Diabetes 59, 172-181.

339. Michaeli B, Berger MM, Revelly JP, et al. (2007) Effects of fish oil on the neuro-endocrine responses to an endotoxin challenge in healthy volunteers. Clin Nutr 26, 70-77.

340. Brydon L, Walker C, Wawrzyniak A, et al. (2009) Synergistic effects of psychological and immune stressors on inflammatory cytokine and sickness responses in humans. Brain Behav Immun 23, 217-224. 